National Water-Quality Assessment Program

\title{
Pesticide Trends in Major Rivers of the United States, 1992-2010
}

Scientific Investigations Report 2014-5135

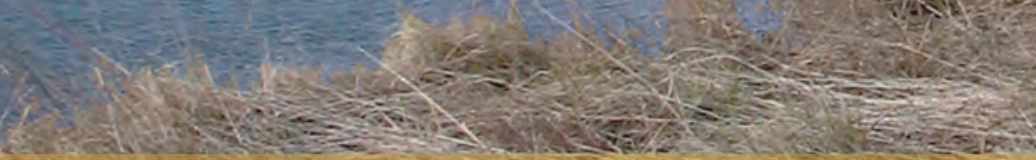

U.S. Department of the Interior

U.S. Geological Survey 
Cover. View of Missouri River from Double Ditch Indian Village Historic Site, north of Bismarck, North Dakota, September 26, 2006 (photograph by Kathleen Macek-Rowland). 


\section{Pesticide Trends in Major Rivers of the United States, 1992-2010}

By Karen R. Ryberg, Aldo V. Vecchia, Robert J. Gilliom, and Jeffrey D. Martin

National Water-Quality Assessment Program

Scientific Investigations Report 2014-5135 


\title{
U.S. Department of the Interior SALLY JEWELL, Secretary
}

\section{U.S. Geological Survey Suzette M. Kimball, Acting Director}

\author{
U.S. Geological Survey, Reston, Virginia: 2014
}

For more information on the USGS - the Federal source for science about the Earth, its natural and living resources, natural hazards, and the environment, visit http://www.usgs.gov or call 1-888-ASK-USGS.

For an overview of USGS information products, including maps, imagery, and publications, visit http://www.usgs.gov/pubprod

To order this and other USGS information products, visit http://store.usgs.gov

Any use of trade, firm, or product names is for descriptive purposes only and does not imply endorsement by the U.S. Government.

Although this information product, for the most part, is in the public domain, it also may contain copyrighted materials as noted in the text. Permission to reproduce copyrighted items must be secured from the copyright owner.

Suggested citation:

Ryberg, K.R., Vecchia, A.V., Gilliom, R.J., and Martin, J.D., 2014, Pesticide trends in major rivers of the United States, 1992-2010: U.S. Geological Survey Scientific Investigations Report 2014-5135, 63 p., http://dx.doi.org/10.3133/ sir20145135.

ISSN 2328-0328 (online) 


\section{Contents}

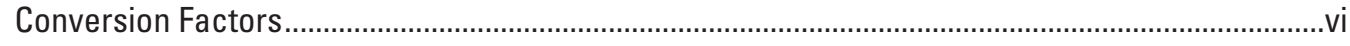

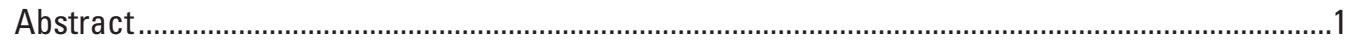

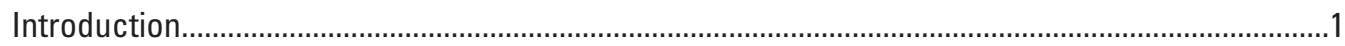

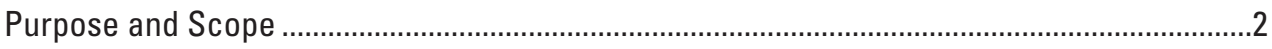

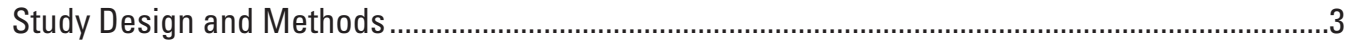

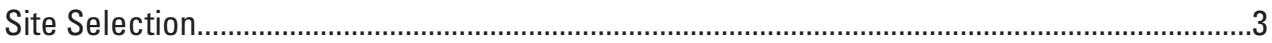

Sample Collection, Processing, and Field Quality-Control Program ..........................................7

Analytical Methods for Pesticides.........................................................................................

Sources and Preparation of Concentration Data for Trend Analysis.......................................7

Sources and Preparation of Agricultural-use Intensity Data for Trend Analysis .....................8

Selection of Pesticides and Periods for Trend Analysis ............................................................8

Statistical Method for Analyzing Trends in Pesticide Concentrations ....................................12

Statistical Method for Analyzing Trends in Agricultural Use ..................................................13

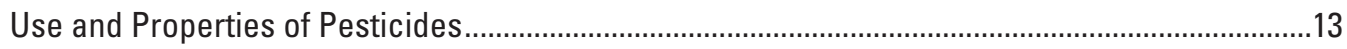

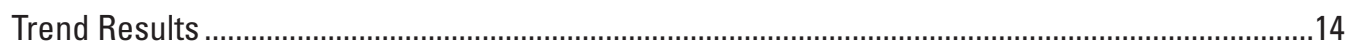

National Analysis of Independent Trend Sites..............................................................................22

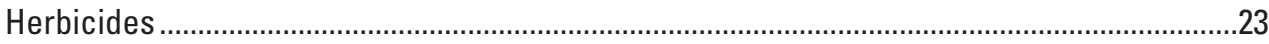

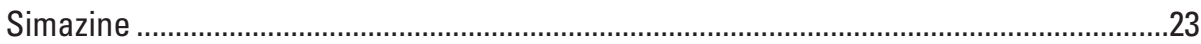

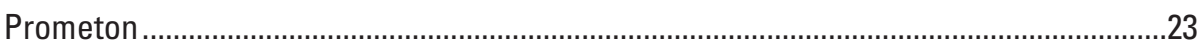

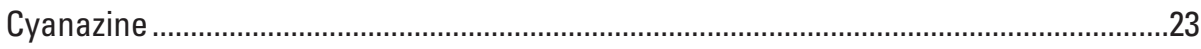

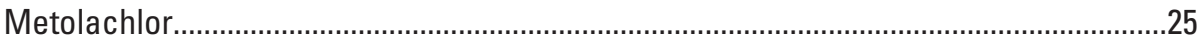

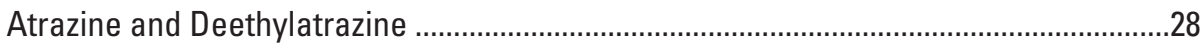

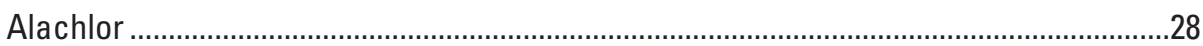

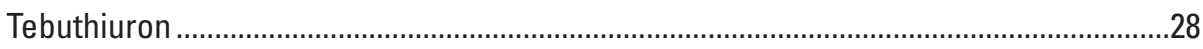

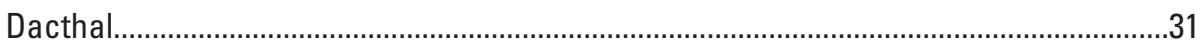

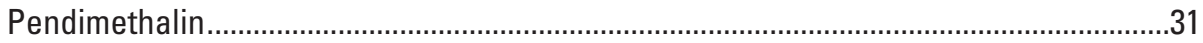

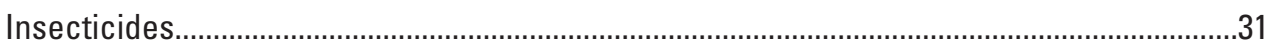

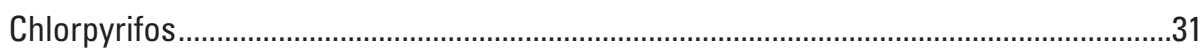

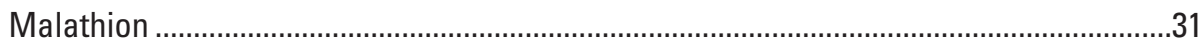

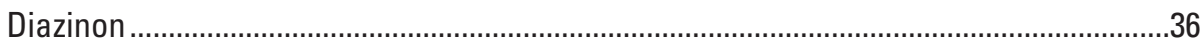

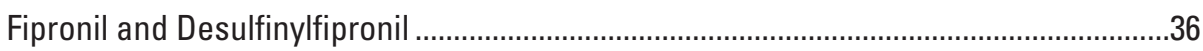

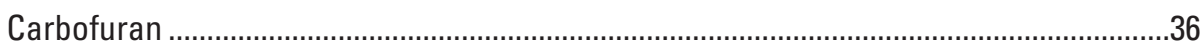

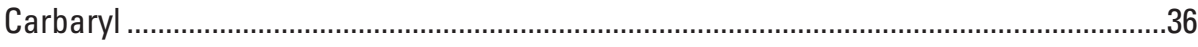

Nested Basin Analysis for the Mississippi River Basin .............................................................42

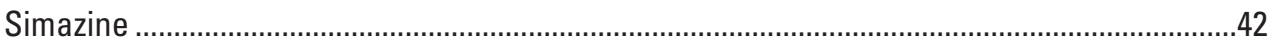

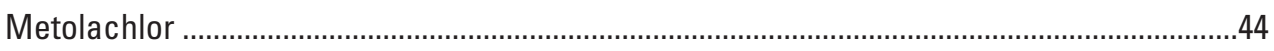

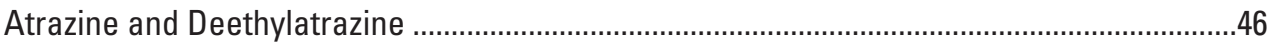

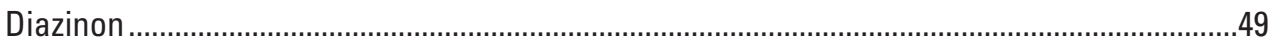

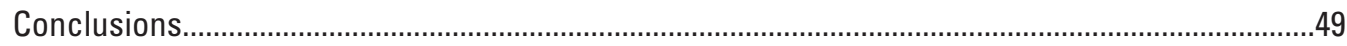

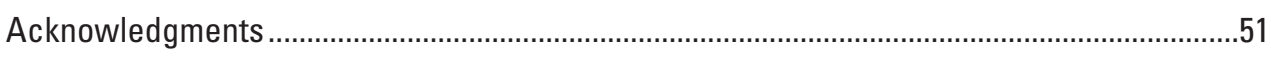

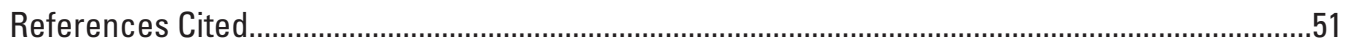

Appendix 1. Preparation of Concentration Data for Trend Analysis ................................................58

Appendix 2. Examples of Agricultural-Use Intensity Data and Interval Censored Trend Analysis 


\section{Figures}

1. Graph showing estimated agricultural pesticide use in the conterminous United States, 1992-2010.

2. Map showing sampling sites (table1) used for analysis of pesticide concentration trends in major rivers, 1992-2010.

3. Graphs showing total conterminous U.S. agricultural use for herbicides and insecticides by year and crop, 1992-2010

4. Maps showing simazine concentration and agricultural-use trends at independent trend sites, 1992-2010

5. Maps showing prometon concentration trends at independent trend sites, 1992-2010.

6. Maps showing cyanazine concentration and agricultural-use trends at independent trend sites, 1992-2010.

7. Maps showing metolachlor concentration and agricultural-use trends at independent trend sites, 1992-2010.

8. Maps showing atrazine and deethylatrazine concentration trends and atrazine agricultural-use trends at independent trend sites, 1992-2010

9. Maps showing alachlor concentration and agricultural-use trends at independent trend sites, 1992-2010

10. Maps showing tebuthiuron concentration and agricultural-use trends at independent trend sites, 1992-2010.

11. Maps showing dacthal concentration and agricultural-use trends at independent trend sites, 1992-2010

12. Maps showing pendimethalin concentration and agricultural-use trends at independent trend sites, 1992-2010.

13. Maps showing chlorpyrifos concentration and agricultural-use trends at independent trend sites, 1992-2010.

14. Maps showing malathion concentration and agricultural-use trends at independent trend sites, 1992-2010.....

15. Maps showing diazinon concentration and agricultural-use trends at independent trend sites, 1992-2010

16. Maps showing fipronil and desulfinylfipronil concentration and fipronil agricultural-use trends at independent trend sites, 1992-2010.

17. Maps showing carbofuran concentration and agricultural-use trends at independent trend sites, 1992-2010.

18. Maps showing carbaryl concentration and agricultural-use trends at independent trend sites, 1992-2010

19. Graphs showing simazine concentration and agricultural-use trends for nested basins in the Mississippi River Basin for 1997-2006 and 2001-10.

20. Graphs showing metolachlor concentration and agricultural-use trends for nested basins in the Mississippi River Basin for trend periods 2, 1997-2006, and 3, 2001-10.

21. Graphs showing atrazine concentration and agricultural-use trends for nested basins in the Mississippi River Basin for trend periods 2, 1997-2006, and 3, 2001-10.

22. Graphs showing deethylatrazine concentration and atrazine agricultural-use trends for nested basins in the Mississippi River Basin for trend periods 2, 1997-2006, and 3, 2001-10. 
23. Graphs showing diazinon concentration and agricultural-use trends for nested basins in the Mississippi River Basin for trend periods 2, 1997-2006, and 3, 2001-10

\section{Appendix Figures}

2-1. Graphs showing atrazine agricultural-use intensity, in kilograms per square kilometer, for major river basins with agricultural land use and reported atrazine use, 1992-2010...

2-2. Graphs showing diazinon agricultural-use intensity, in kilograms per square kilometer, for major river basins with agricultural land use and reported diazinon use, 1992-2010

2-3. Graphs showing EPest-high and EPest-low estimates and censored regression trends for atrazine at four sites, 1992-2010.

\section{Tables}

1. Descriptive information for sites on major rivers selected for pesticide trend analysis, 1992-2010, grouped by National Water Quality Assessment Program modeling regions

2. Pesticides and degradates selected for 1992-2010 major rivers trend analysis..............9

3. Properties affecting the transport and fate of pesticides and degradates selected for trend analysis

4. Property classifiers as guidelines for assessing the properties affecting the transport and fate of pesticides and degradates.

5. Trend analysis results for herbicide concentration and agricultural-use trends in major rivers, 1992-2010

6. Trend analysis results for acaricide and insecticide concentration and agricultural-use trends in major rivers, 1992-2010 


\section{Conversion Factors}

SI to Inch/Pound

\begin{tabular}{|c|c|c|}
\hline Multiply & By & To obtain \\
\hline \multicolumn{3}{|c|}{ Length } \\
\hline micrometer $(\mu \mathrm{m})$ & 0.00003937 & inch (in.) \\
\hline centimeter $(\mathrm{cm})$ & 0.3937 & inch (in.) \\
\hline millimeter (mm) & 0.03937 & inch (in.) \\
\hline meter $(\mathrm{m})$ & 3.281 & foot $(\mathrm{ft})$ \\
\hline kilometer (km) & 0.6214 & mile (mi) \\
\hline meter (m) & 1.094 & yard (yd) \\
\hline \multicolumn{3}{|c|}{ Area } \\
\hline square kilometer $\left(\mathrm{km}^{2}\right)$ & 247.1 & acre \\
\hline square centimeter $\left(\mathrm{cm}^{2}\right)$ & 0.001076 & square foot $\left(\mathrm{ft}^{2}\right)$ \\
\hline square meter $\left(\mathrm{m}^{2}\right)$ & 10.76 & square foot $\left(\mathrm{ft}^{2}\right)$ \\
\hline square centimeter $\left(\mathrm{cm}^{2}\right)$ & 0.1550 & square inch $\left(\mathrm{ft}^{2}\right)$ \\
\hline square kilometer $\left(\mathrm{km}^{2}\right)$ & 0.3861 & square mile $\left(\mathrm{mi}^{2}\right)$ \\
\hline \multicolumn{3}{|c|}{ Volume } \\
\hline liter $(\mathrm{L})$ & 33.82 & ounce, fluid (fl. oz) \\
\hline liter $(\mathrm{L})$ & 0.2642 & gallon (gal) \\
\hline \multicolumn{3}{|c|}{ Flow rate } \\
\hline cubic meter per second $\left(\mathrm{m}^{3} / \mathrm{s}\right)$ & 35.31 & cubic foot per second $\left(\mathrm{ft}^{3} / \mathrm{s}\right)$ \\
\hline cubic meter per hour $\left(\mathrm{m}^{3} / \mathrm{h}\right)$ & 39.37 & inch per hour (in/h) \\
\hline \multicolumn{3}{|c|}{ Mass } \\
\hline milligrams (mg) & 0.00003527 & ounce, avoirdupois (oz) \\
\hline gram $(\mathrm{g})$ & 0.03527 & ounce, avoirdupois (oz) \\
\hline kilogram (kg) & 2.205 & pound avoirdupois (lb) \\
\hline \multicolumn{3}{|c|}{ Gas Constant } \\
\hline $\begin{array}{l}\text { Pascal-cubic meters per mole } \\
\qquad\left(\mathrm{Pa} \cdot \mathrm{m}^{3} / \mathrm{mol}\right)\end{array}$ & 0.158 & $\begin{array}{l}\text { Standard atmosphere cubic feet per } \\
\left.\text { pound mole (atm } \mathrm{f}^{3} / \mathrm{lb}-\mathrm{mol}\right)\end{array}$ \\
\hline
\end{tabular}

Temperature in degrees Celsius $\left({ }^{\circ} \mathrm{C}\right)$ may be converted to degrees Fahrenheit $\left({ }^{\circ} \mathrm{F}\right)$ as follows:

${ }^{\circ} \mathrm{F}=\left(1.8 x^{\circ} \mathrm{C}\right)+32$

Temperature in degrees Fahrenheit $\left({ }^{\circ} \mathrm{F}\right)$ may be converted to degrees Celsius $\left({ }^{\circ} \mathrm{C}\right)$ as follows:

${ }^{\circ} \mathrm{C}=\left({ }^{\circ} \mathrm{F}-32\right) / 1.8$

Horizontal coordinate information is referenced to North American Datum of 1983 (NAD 83).

Concentrations of chemical constituents in water are given either in micrograms per liter $(\mu \mathrm{g} / \mathrm{L})$. 


\title{
Pesticide Trends in Major Rivers of the United States, 1992-2010
}

\author{
By Karen R. Ryberg, Aldo V. Vecchia, Robert J. Gilliom, and Jeffrey D. Martin
}

\section{Abstract}

This report is part of a series of pesticide trend assessments led by the National Water-Quality Assessment Program of the U.S. Geological Survey. This assessment focuses on major rivers of various sizes throughout the United States that have large watersheds with a range of land uses, changes in pesticide use, changes in management practices, and natural influences typical of the regions being drained.

Trends were assessed at 59 sites for 40 pesticides and pesticide degradates during each of three overlapping periods: 1992-2001, 1997-2006, and 2001-10. In addition to trends in concentration, trends in agricultural-use intensity (agricultural use) were also assessed at 57 of the sites for 35 parent compounds with agricultural uses during the same three periods. The SEAWAVE-Q model was used to analyze trends in concentration, and parametric survival regression for intervalcensored data was used to assess trends in agricultural use. All trends are provided in downloadable electronic files.

A subset of 39 sites was chosen to represent non-nested, generally independent basins for a national analysis of pesticide and agricultural-use trends for the most prevalent pesticides ( 15 pesticides and 2 degradation products). Graphical and numerical results are presented to provide a national overview of concentration and use trends. As another perspective on understanding pesticide concentration trends in large rivers in relation to multiple tributary watersheds, this report also presents a detailed assessment of concentration and use trends for simazine, metolachlor, atrazine, deethylatrazine, and diazinon for a set of 17 nested sites in the Mississippi River Basin (including the Ohio and Missouri River Basins), for the second and third trend periods

Pesticides strongly dominated by agricultural usecyanazine, metolachlor, atrazine, and alachlor - had widespread agreement between concentration trends and agricultural-use trends. Pesticides with substantial use in agricultural and urban applications-simazine, tebuthiuron, Dacthal, pendimethalin, chlorpyrifos, malathion, diazinon, fipronil, carbofuran, and carbaryl - had concentration trends that were mostly explained by a combination of agricultural-use trends and concentration trends in urban streams that were evaluated in a separate companion study. The importance of the urban stream trends for explaining concentration trends in major rivers indicates the significance of nonagricultural uses of some pesticides to concentrations in major rivers despite the much smaller area of urban land use compared to agriculture. Deethylatrazine, a degradate of atrazine, was the only pesticide compound assessed that had frequent occurrences during 1997-2006 and 2001-10 of concentration trends in the opposite direction of use trends (atrazine use). The nested analysis for the Mississippi River indicates that most trends observed in the largest rivers-multiple Mississippi River sites, the Ohio River, and the Missouri River - are consistent with streamflow contributions and concentration trends observed at tributary sites.

Streamflow (incorporated into the trend model and shown in the nested basin analysis), trends in agricultural use of pesticides (quantified in this report), and urban use of pesticides (represented by concentration trends in a companion study of urban streams) are all important influences on pesticide concentrations in streams and rivers. Consideration of these influences is vital to understanding trends in pesticide concentrations.

\section{Introduction}

More than 513 million kilograms $(\mathrm{kg})$ of pesticides (including herbicides, insecticides, fungicides, and other pesticides) were used in 2007 in the United States for agricultural and nonagricultural purposes (Grube and others, 2011). These pesticides are used to control weeds, insects and other pests in agricultural areas, urban areas, and a variety of other landuse settings (Gilliom and others, 2006a). During 1992-2010, there were various periods of declines and increases in the agricultural use of specific types of pesticides and a gradual decline in the total mass of pesticides used for agriculture during 1997-2009 (fig. 1), but the large increases and decreases in use of individual pesticides were more important than the overall use.

The use of pesticides has resulted in a range of benefits, including increased food production and a decrease in insectborne disease, but the use of pesticides also raises concerns about possible adverse effects on the environment, including water quality. Once released into the environment, pesticides 


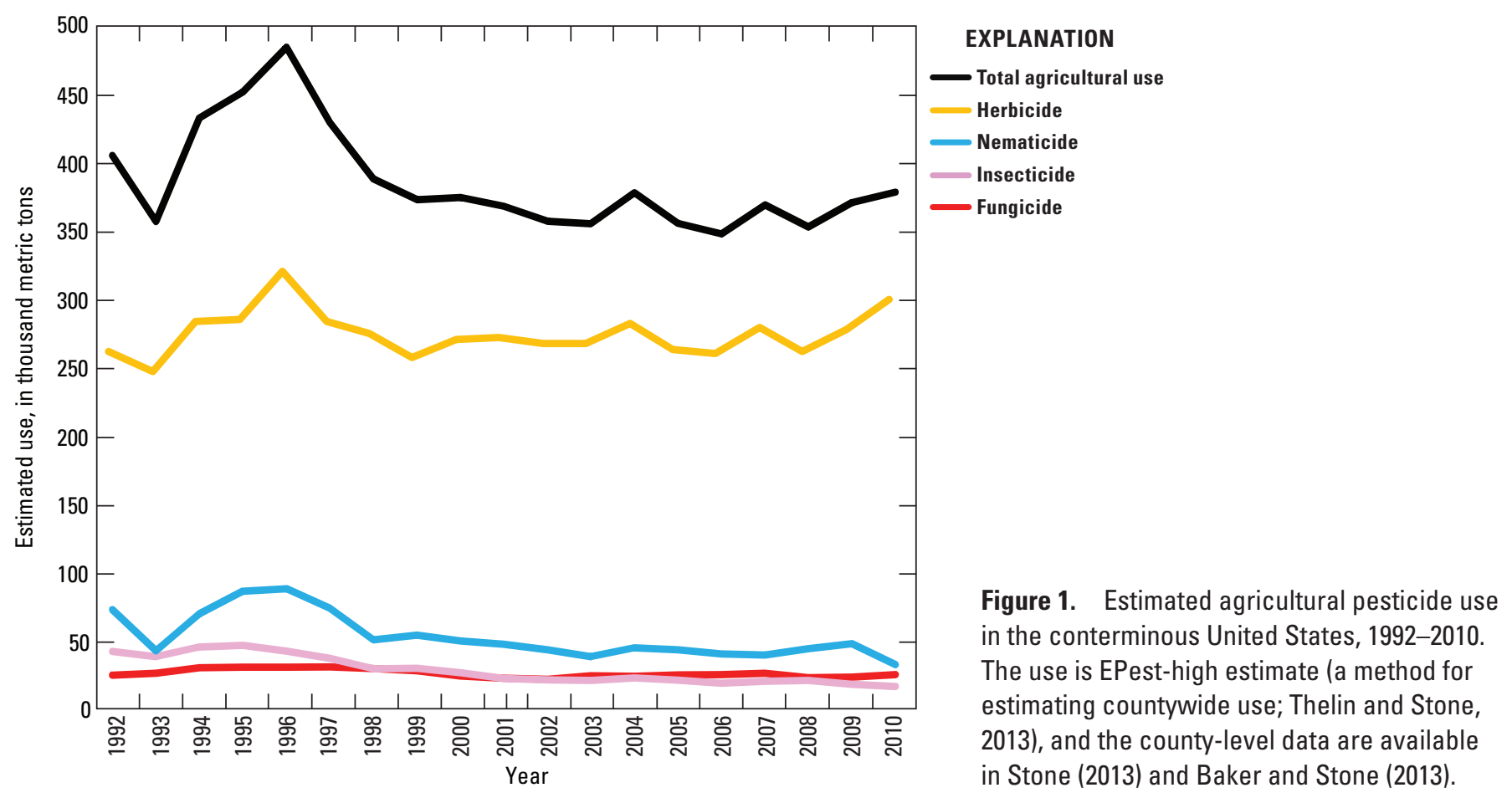

can move through the hydrologic system to streams and groundwater, where they may have unintended effects on humans, aquatic life, or wildlife (Gilliom and others, 2006a). The National Water-Quality Assessment (NAWQA) Program of the U.S. Geological Survey (USGS) led a series of regional and national assessments of pesticide trends for streams with a variety of land use, geographic, and hydrologic settings throughout the United States, including streams and rivers of the Corn Belt (Sullivan and others, 2009; Vecchia and others, 2009) and urban streams nationwide (Ryberg and others, 2010). This report analyzes pesticide trends in selected major rivers of the United States. None of the assessments in this report comprehensively report trends in all of the pesticides used in the environment, but provide trend results for pesticides that are part of the NAWQA monitoring program and for which there are sufficient detections.

Evaluation of trends in pesticide concentrations in major rivers across the United States provides a unique perspective on large-scale trends in different hydrologic and land-use settings. Most major rivers, although their watershed sizes vary greatly, are affected by pesticide sources associated with a wide range of agricultural and urban land uses that are typical of their region. Pesticide trends in these rivers potentially may reflect changes in land use (such as increased urbanization), changes in pesticide use (such as those due to crop changes, regulatory changes, or market forces), and changes in management practices (such as tillage practices or conservation buffer strips). Generally, trends in these rivers are only assessable for pesticides that are used extensively, are relatively water soluble, and are persistent enough to be frequently detected in filtered water at sampling sites (Gilliom and others, 2006a). By identifying the directions, periods, and statistical significance of past trends, in context with changes in use and regulation, this study provides a step toward understanding the attribution of trends to their causes and evaluation of the potential significance of trends to other streams in the region.

\section{Purpose and Scope}

The purpose of this report is to (1) assess trends during 1992-2010 in the water concentrations of commonly detected pesticides that are part of the NAWQA monitoring program for 59 sites located on major rivers of the United States (fig. 2), (2) assess trends in agricultural pesticide use within the drainage basins of these rivers, and (3) interpret the concentration trends in relation to potential causes, particularly pesticide use and regulation during 1992-2010. Concentration trends were assessed for 40 pesticides and pesticide degradates at one or more sites, including 25 herbicides and 1 herbicide degradation product, and 11 insecticides (including 1 acaricide) and 3 insecticide degradation products. Agricultural-use intensity trends, hereafter called agricultural-use trends, were assessed for the 35 parent compounds that have agricultural uses.

Pesticide concentrations for the 59 study sites were analyzed for trends during each of three overlapping periods: 1992-2001, 1997-2006, and 2001-10. Depending on minimum data requirements for assessing trends as described in the "Selection of Pesticides and Time Periods for Trend Analysis" section, different subsets of the sites were included for each period and pesticide. 


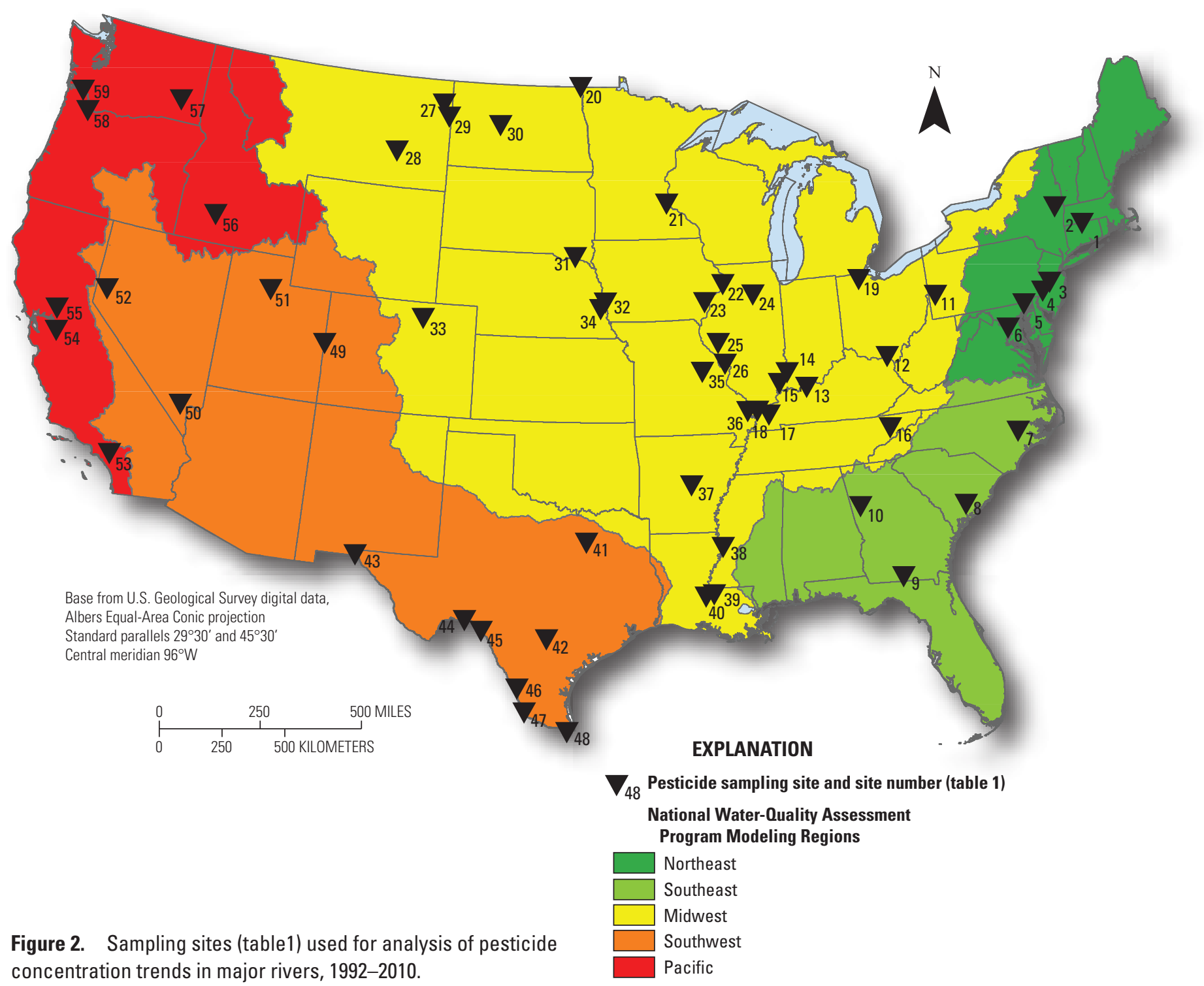

\section{Study Design and Methods}

\section{Site Selection}

The 59 river sites analyzed in this study (table 1; fig. 2) are a subset of 212 sites that were sampled as part of NAWQA studies and the USGS National Stream Quality Accounting Network (NASQAN), and were selected as part of a national set of sites that have surface-water pesticide concentration data that are adequate for trend analysis (Martin and others, 2011). The 59 sites are classified as "integrator sites" in the NAWQA program design. Integrator sites represent water quality in rivers at outlets of large basins that are often affected by mixed land uses or a wide variety of natural influences typical of a region (Gilliom and others, 2006b). Hereinafter, these sites and those of the NASQAN network are collectively referred to as "major river sites."
Selection of sites for this study was based on meeting the following criteria:

- At least 10 uncensored concentrations (detections) of one or more pesticides in this study in at least one of the three trend periods.

- All sites were required to have streamflow data concurrent with the period of pesticide data. For some sites, streamflow data were not available at the same location where water samples were collected; therefore, streamflow data were obtained from a nearby site. The sites for which streamflow data were obtained from a nearby site are listed in table 1 . In some cases, the streamflow data were provided by another agency and that is indicated in table 1. 
Table 1. Descriptive information for sites on major rivers selected for pesticide trend analysis, 1992-2010, grouped by National Water Quality Assessment Program modeling regions.

[Site short name, used for reference in text, figures, and tables, and is the same short name used in Ryberg and others (2010) and Sullivan and others (2009), if the site appeared in those reports; drainage area provided by Nancy Baker of the Nation Water-Quality Assessment Program National Monitoring and Status Assessment Team (written commun., 2013); Urban, Ryberg and others (2010); Corn-Belt, Sullivan and others (2009); USGS, U.S. Geological Survey; $\mathrm{km}^{2}$, square kilometers; --, not included in study; T, indicates the site was included in the general trend analysis of all site/period/pesticide combinations for which there were sufficient data; I, indicates the site was included in the national analysis of independent, non-nested basins; na, not available; N, indicates the site was included in the nested analysis for the Mississippi River Basin; TVA, Tennessee Valley Authority; EC, Environmental Canada; USACE, U.S. Army Corps of Engineers; IBWC, International Boundary Waters Commission]

\begin{tabular}{|c|c|c|c|c|c|c|c|c|c|}
\hline 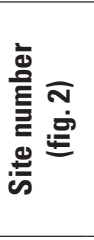 & $\begin{array}{l}\text { Site short } \\
\text { name }\end{array}$ & $\begin{array}{l}\text { USGS } \\
\text { station } \\
\text { number }\end{array}$ & Site name & $\begin{array}{c}\text { Drainage } \\
\text { area } \\
\left(\mathbf{k m}^{2}\right)\end{array}$ & $\begin{array}{l}\text { Previous } \\
\text { pesticide } \\
\text { trends study } \\
\text { in which } \\
\text { site was } \\
\text { included }\end{array}$ & $\begin{array}{c}\text { Trend } \\
\text { analyses }\end{array}$ & $\begin{array}{c}\text { Alternative } \\
\text { streamgage } \\
\text { station } \\
\text { identifier }\end{array}$ & Alternative streamgage site name & $\begin{array}{l}\text { Agency that } \\
\text { provided the } \\
\text { streamflow } \\
\text { data }\end{array}$ \\
\hline \multicolumn{10}{|c|}{ Northeast } \\
\hline 1 & CONNR & 01184000 & Connecticut River at Thompsonville, Conn. & 25,015 & -- & T, I & & na & USGS \\
\hline 2 & MOHWK & 01357500 & Mohawk River at Cohoes, N.Y. & 8,972 & -- & $\mathrm{T}, \mathrm{I}$ & & na & USGS \\
\hline 3 & DELA-TR & 01463500 & Delaware River at Trenton, N.J. & 17,574 & -- & $\mathrm{T}, \mathrm{I}$ & & na & USGS \\
\hline 4 & SCHYL & 01474500 & Schuylkill River at Philadelphia, Pa. & 4,903 & -- & $\mathrm{T}, \mathrm{I}$ & & na & USGS \\
\hline 5 & SUSQU & 01578310 & Susquehanna River at Conowingo, Md. & 70,137 & -- & $\mathrm{T}, \mathrm{I}$ & & na & USGS \\
\hline 6 & POTOM & 01646580 & $\begin{array}{l}\text { Potomac River at Chain Bridge, at Wash- } \\
\text { ington, D.C. }\end{array}$ & 29,976 & -- & $\mathrm{T}, \mathrm{I}$ & 01646500 & $\begin{array}{l}\text { Potomac River near Washington, } \\
\text { D.C., Little Falls Pumping Station }\end{array}$ & USGS \\
\hline \multicolumn{10}{|c|}{ Southeast } \\
\hline 7 & NEUS-KN & 02089500 & Neuse River at Kinston, N.C. & 7,013 & -- & $\mathrm{T}, \mathrm{I}$ & & na & USGS \\
\hline 8 & EDIST & 02175000 & Edisto River near Givhans, S.C. & 7,064 & -- & $\mathrm{T}, \mathrm{I}$ & & na & USGS \\
\hline 9 & WTHLC & 02318500 & $\begin{array}{l}\text { Withlacoochee River at U.S. Highway } 84 \\
\text { near Quitman, Ga. }\end{array}$ & 3,864 & -- & $\mathrm{T}, \mathrm{I}$ & & na & USGS \\
\hline 10 & CHATT & 02338000 & Chattahoochee River near Whitesburg, Ga. & 6,252 & Urban & $\mathrm{T}, \mathrm{I}$ & & na & USGS \\
\hline \multicolumn{10}{|c|}{ Midwest } \\
\hline 11 & OHIO-SW & 03086000 & Ohio River at Sewickly, Pa. & 50,488 & -- & $\mathrm{T}$ & & na & USGS \\
\hline 12 & OHIO-GU & 03216600 & $\begin{array}{l}\text { Ohio River at Greenup Dam near Greenup, } \\
\text { Ky. }\end{array}$ & 159,544 & -- & $\mathrm{T}, \mathrm{I}, \mathrm{N}$ & & na & USGS \\
\hline 13 & OHIO-CA & 03303280 & $\begin{array}{l}\text { Ohio River at Cannelton Dam at Cannel- } \\
\text { ton, Ind. }\end{array}$ & 249,908 & Corn-Belt & $\mathrm{T}, \mathrm{N}$ & & na & USGS \\
\hline 14 & WHITE & 03374100 & White River at Hazleton, Ind. & 29,295 & Corn-Belt & $\mathrm{T}, \mathrm{I}, \mathrm{N}$ & 03374000 & White River at Petersburg, Ind. & USGS \\
\hline 15 & WABASH & 03378500 & Wabash River at New Harmony, Ind. & 75,894 & Corn-Belt & $\mathrm{T}, \mathrm{N}$ & 03377500 & Wabash River at Mt. Carmel, Ill. & USGS \\
\hline 16 & NOLCH & 03467609 & Nolichucky River near Lowland, Tenn. & 4,374 & -- & $\mathrm{T}, \mathrm{I}$ & & na & \\
\hline 17 & TENNS & 03609750 & $\begin{array}{l}\text { Tennessee River at Highway } 60 \text { near } \\
\text { Paducah, Ky. }\end{array}$ & 104,458 & -- & $\mathrm{T}, \mathrm{I}, \mathrm{N}$ & kyhr & Kentucky Reservoir outflow & TVA \\
\hline 18 & $\begin{array}{l}\text { OHIO- } \\
\text { GRCH }\end{array}$ & 03612500 & $\begin{array}{l}\text { Ohio River at Dam } 53 \text { near Grand Chain } \\
\text { Ill. }\end{array}$ & 527,432 & Corn-Belt & $\mathrm{T}, \mathrm{N}$ & 03611500 & Ohio River at Metropolis, Ill. & USGS \\
\hline 19 & MAUM & 04193500 & Maumee River at Waterville, Ohio & 16,303 & Corn-Belt & $\mathrm{T}, \mathrm{I}$ & & na & \\
\hline 20 & REDRV & 05102490 & $\begin{array}{l}\text { Red River of the North at Pembina, N. } \\
\text { Dak. }\end{array}$ & 103,294 & -- & $\mathrm{T}, \mathrm{I}$ & 05102500 & $\begin{array}{l}\text { Red River of the North at Emerson, } \\
\text { Manitoba }\end{array}$ & EC \\
\hline
\end{tabular}


Table 1. Descriptive information for sites on major rivers selected for pesticide trend analysis, 1992-2010, grouped by National Water Quality Assessment Program modeling regions.-Continued

[Site short name, used for reference in text, figures, and tables, and is the same short name used in Ryberg and others (2010) and Sullivan and others (2009), if the site appeared in those reports; drainage area provided by Nancy Baker of the Nation Water-Quality Assessment Program National Monitoring and Status Assessment Team (written commun., 2013); Urban, Ryberg and others (2010); Corn-Belt, Sullivan and others (2009); USGS, U.S. Geological Survey; $\mathrm{km}^{2}$, square kilometers; --, not included in study; T, indicates the site was included in the general trend analysis of all site/period/pesticide combinations for which there were sufficient data; I, indicates the site was included in the national analysis of independent, non-nested basins; na, not available; $\mathrm{N}$, indicates the site was included in the nested analysis for the Mississippi River Basin; TVA, Tennessee Valley Authority; USACE, U.S. Army Corps of Engineers; IBWC, International Boundary Waters Commission]

\begin{tabular}{|c|c|c|c|c|c|c|c|c|c|}
\hline 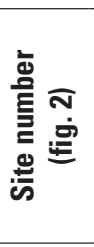 & $\begin{array}{l}\text { Site short } \\
\text { name }\end{array}$ & $\begin{array}{c}\text { USGS } \\
\text { station } \\
\text { number }\end{array}$ & Site name & $\begin{array}{c}\text { Drainage } \\
\text { area } \\
\left(\mathrm{km}^{2}\right)\end{array}$ & $\begin{array}{l}\text { Previous } \\
\text { pesticide } \\
\text { trends study } \\
\text { in which } \\
\text { site was } \\
\text { included }\end{array}$ & $\begin{array}{c}\text { Trend } \\
\text { analyses }\end{array}$ & $\begin{array}{c}\text { Alternative } \\
\text { streamgage } \\
\text { station } \\
\text { identifier }\end{array}$ & Alternative streamgage site name & $\begin{array}{l}\text { Agency that } \\
\text { provided the } \\
\text { streamflow } \\
\text { data }\end{array}$ \\
\hline \multicolumn{10}{|c|}{ Midwest-Continued } \\
\hline 21 & MSSP-HA & 05331580 & $\begin{array}{l}\text { Mississippi River below Lock and Dam } 2 \\
\text { at Hastings, Minn. }\end{array}$ & 96,126 & Corn-Belt & $\mathrm{T}$ & & na & USGS \\
\hline 22 & MSSP-CL & 05420500 & Mississippi River at Clinton, Iowa & 222,454 & Corn-Belt & $\mathrm{T}, \mathrm{I}, \mathrm{N}$ & & na & USGS \\
\hline 23 & $\begin{array}{l}\text { IOWA- } \\
\text { WAP }\end{array}$ & 05465500 & Iowa River at Wapello, Iowa & 32,397 & Corn-Belt & $\mathrm{T}, \mathrm{I}, \mathrm{N}$ & & na & USGS \\
\hline 24 & ILLI-OTT & 05553500 & Illinois River at Ottawa, Ill. & 28,319 & Corn-Belt & $\mathrm{T}$ & 05543500 & Illinois River at Marseilles, Ill. & USGS \\
\hline 25 & ILLI-VC & 05586100 & Illinois River at Valley City, Ill. & 69,119 & Corn-Belt & $\mathrm{T}, \mathrm{I}, \mathrm{N}$ & & na & USGS \\
\hline 26 & MSSP-GR & 05587455 & Mississippi River below Grafton, Ill. & 446,884 & Corn-Belt & $\mathrm{T}, \mathrm{N}$ & 05587450 & Mississippi River at Grafton, Ill. & USGS \\
\hline 27 & MIZZ-CB & 06185500 & Missouri River near Culbertson, Mont. & 238,654 & -- & $\mathrm{T}, \mathrm{I}$ & & na & USGS \\
\hline 28 & YLOW-FS & 06295000 & Yellowstone River at Forsyth, Mont. & 103,982 & -- & $\mathrm{T}$ & & na & USGS \\
\hline 29 & YLOW-SN & 06329500 & Yellowstone River near Sidney, Mont. & 178,937 & -- & $\mathrm{T}, \mathrm{I}$ & & na & USGS \\
\hline 30 & MIZZ-GD & 06338490 & Missouri River at Garrison Dam, N. Dak. & 468,612 & -- & $\mathrm{T}$ & & na & USGS \\
\hline 31 & MIZZ-YT & 06467500 & Missouri River at Yankton, S. Dak. & 721,793 & -- & $\mathrm{T}$ & YKN & Missouri River at Yankton, S. Dak. & USACE \\
\hline 32 & MIZZ-OM & 06610000 & Missouri River at Omaha, Nebr. & 831,564 & Corn-Belt & $\mathrm{T}, \mathrm{N}$ & & na & USGS \\
\hline 33 & SPLT-KR & 06754000 & South Platte River near Kersey, Colo. & 25,259 & -- & $\mathrm{T}, \mathrm{I}$ & & na & USGS \\
\hline 34 & PLATTE & 06805500 & Platte River at Louisville, Nebr. & 221,020 & Corn-Belt & $\mathrm{T}, \mathrm{I}, \mathrm{N}$ & & na & USGS \\
\hline 35 & MIZZ-HE & 06934500 & Missouri River at Hermann, Mo. & $1,345,287$ & Corn-Belt & $\mathrm{T}, \mathrm{N}$ & & na & USGS \\
\hline 36 & MSSP-TH & 07022000 & Mississippi River at Thebes, Ill. & $1,840,068$ & Corn-Belt & $\mathrm{T}, \mathrm{N}$ & & na & USGS \\
\hline 37 & ARKNS & 07263620 & $\begin{array}{l}\text { Arkansas River at David D. Terry Lock and } \\
\text { Dam, below Little Rock, Ark. }\end{array}$ & 408,663 & -- & $\mathrm{T}, \mathrm{I}, \mathrm{N}$ & 07263450 & $\begin{array}{l}\text { Arkansas River at Murray Dam, near } \\
\text { Little Rock, Ark. }\end{array}$ & USGS \\
\hline 38 & YAZOO & 07288955 & $\begin{array}{l}\text { Yazoo River below Steele Bayou, near } \\
\text { Long Lake, Miss. }\end{array}$ & 34,738 & -- & $\mathrm{T}, \mathrm{I}, \mathrm{N}$ & & na & USGS \\
\hline 39 & MSSP-SF & 07373420 & Mississippi River near St. Francisville, La. & $2,965,240$ & -- & $\mathrm{T}, \mathrm{N}$ & 01100 & $\begin{array}{l}\text { Mississippi River at Tarbert Landing, } \\
\text { Miss. }\end{array}$ & USACE \\
\hline 40 & ATCHF & 07381495 & Atchafalaya River at Melville, La. & 242,192 & -- & $\mathrm{T}$ & 03045 & $\begin{array}{l}\text { Atchafalaya River At Simmesport, } \\
\text { La. }\end{array}$ & USACE \\
\hline \multicolumn{10}{|c|}{ Southwest } \\
\hline 41 & TRNTY & 08057410 & Trinity River below Dallas, Tex. & 16,226 & -- & $\mathrm{T}, \mathrm{I}$ & & na & USGS \\
\hline 42 & SNANT & 08181800 & San Antonio River near Elmendorf, Tex. & 4,501 & -- & $\mathrm{T}, \mathrm{I}$ & & na & USGS \\
\hline
\end{tabular}


Table 1. Descriptive information for sites on major rivers selected for pesticide trend analysis, 1992-2010, grouped by National Water Quality Assessment Program modeling regions.-Continued

[Site short name, used for reference in text, figures, and tables, and is the same short name used in Ryberg and others (2010) and Sullivan and others (2009), if the site appeared in those reports; drainage area provided by Nancy Baker of the Nation Water-Quality Assessment Program National Monitoring and Status Assessment Team (written commun., 2013); Urban, Ryberg and others (2010); Corn-Belt, Sullivan and others (2009); USGS, U.S. Geological Survey; $\mathrm{km}^{2}$, square kilometers; --, not included in study; T, indicates the site was included in the general trend analysis of all site/period/pesticide combinations for which there were sufficient data; I, indicates the site was included in the national analysis of independent, non-nested basins; na, not available; N, indicates the site was included in the nested analysis for the Mississippi River Basin; TVA, Tennessee Valley Authority; USACE, U.S. Army Corps of Engineers; IBWC, International Boundary Waters Commission]

\begin{tabular}{|c|c|c|c|c|c|c|c|c|c|}
\hline 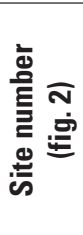 & $\begin{array}{l}\text { Site short } \\
\text { name }\end{array}$ & $\begin{array}{l}\text { USGS } \\
\text { station } \\
\text { number }\end{array}$ & Site name & $\begin{array}{l}\text { Drainage } \\
\text { area } \\
\left(\mathbf{k m}^{2}\right)\end{array}$ & $\begin{array}{l}\text { Previous } \\
\text { pesticide } \\
\text { trends study } \\
\text { in which } \\
\text { site was } \\
\text { included }\end{array}$ & $\begin{array}{l}\text { Trend } \\
\text { analyses }\end{array}$ & $\begin{array}{l}\text { Alternative } \\
\text { streamgage } \\
\text { station } \\
\text { identifier }\end{array}$ & Alternative streamgage site name & $\begin{array}{l}\text { Agency that } \\
\text { provided the } \\
\text { streamflow } \\
\text { data }\end{array}$ \\
\hline \multicolumn{10}{|c|}{ Southwest-Continued } \\
\hline 43 & RIOG-EP & 08364000 & Rio Grande at El Paso, Tex. & 102,704 & -- & $\mathrm{T}, \mathrm{I}$ & $08-3640.00$ & Rio Grande at El Paso, Tex. & IBWC \\
\hline 44 & RIOG-LT & 08377200 & $\begin{array}{l}\text { Rio Grande at Foster Ranch, near Langtry, } \\
\text { Tex. }\end{array}$ & 258,098 & -- & $\mathrm{T}$ & $08-3772.00$ & $\begin{array}{l}\text { Rio Grande at Foster Ranch, near } \\
\text { Langtry, Tex. and Rancho Santa } \\
\text { Rosa, Coahuila }\end{array}$ & IBWC \\
\hline 45 & RIOG-DR & 08450900 & $\begin{array}{l}\text { Rio Grande below Amistad Dam, near Del } \\
\text { Rio, Tex. }\end{array}$ & 390,603 & -- & $\mathrm{T}$ & $08-4509.00$ & $\begin{array}{l}\text { Rio Grande below Amistad Dam, } \\
\text { near Cd. Acuna, Coahuila, and Del } \\
\text { Rio, Tex. }\end{array}$ & IBWC \\
\hline 46 & RIOG-LR & 08459200 & $\begin{array}{l}\text { Rio Grande at Pipline Crossing, below } \\
\text { Laredo, Tex. }\end{array}$ & 405,538 & -- & $\mathrm{T}$ & $08-4590.00$ & $\begin{array}{l}\text { Rio Grande at Laredo, Tex., and } \\
\text { Nuevo Laredo, Tamaulipas }\end{array}$ & IBWC \\
\hline 47 & RIOG-FD & 08461300 & Rio Grande below Falcon Dam, Tex. & 423,471 & -- & $\mathrm{T}$ & $08-4613.00$ & $\begin{array}{l}\text { Rio Grande below Falcon Dam, Tex., } \\
\text { and Nueva Cd. Guerrero, Tamau- } \\
\text { lipas }\end{array}$ & IBWC \\
\hline 48 & RIOG-BV & 08475000 & Rio Grande near Brownsville, Tex. & 557,550 & -- & $\mathrm{T}$ & $08-4750.00$ & $\begin{array}{l}\text { Rio Grande near Brownsville, Tex., } \\
\text { and Matamoros, Tamaulipas }\end{array}$ & IBWC \\
\hline 49 & COLO-SL & 09163500 & $\begin{array}{l}\text { Colorado River near Colorado-Utah State } \\
\text { Line, Colo. }\end{array}$ & 46,217 & -- & $\mathrm{T}, \mathrm{I}$ & & na & USGS \\
\hline 50 & LVWSH & 094196783 & $\begin{array}{l}\text { Las Vegas Wash below Flamingo Wash } \\
\text { Confluence, near Las Vegas, Nev. }\end{array}$ & 3,857 & -- & $\mathrm{T}, \mathrm{I}$ & & na & USGS \\
\hline 51 & JORDN & 10171000 & Jordon River at Salt Lake City, Utah & 9,047 & -- & $\mathrm{T}, \mathrm{I}$ & & na & USGS \\
\hline 52 & TRUCK & 10350500 & Truckee River at Clark, Nev. & 4,143 & -- & $\mathrm{T}, \mathrm{I}$ & 10350340 & Truckee River near Tracey, Nev. & USGS \\
\hline \multicolumn{10}{|c|}{ Pacific } \\
\hline 53 & SANTA & 11074000 & Santa Ana River below Prado Dam, Calif. & 3,880 & Urban & $\mathrm{T}, \mathrm{I}$ & & na & USGS \\
\hline 54 & SJQUN & 11303500 & San Joaquin River near Vernalis, Calif. & 34,989 & -- & $\mathrm{T}, \mathrm{I}$ & & na & USGS \\
\hline 55 & SACRA & 11447650 & Sacramento River at Freeport, Calif. & 61,443 & -- & $\mathrm{T}, \mathrm{I}$ & & na & USGS \\
\hline 56 & SNAK-KH & 13154500 & Snake River at King Hill, Idaho & 92,911 & -- & $\mathrm{T}, \mathrm{I}$ & & na & USGS \\
\hline 57 & PLOUS & 13351000 & Palouse River at Hooper, Wash. & 6,472 & -- & $\mathrm{T}, \mathrm{I}$ & & na & USGS \\
\hline 58 & WILMT & 14211720 & Willamette River at Portland, Oreg. & 28,925 & -- & $\mathrm{T}, \mathrm{I}$ & & na & USGS \\
\hline 59 & CLUM-QY & 14246900 & $\begin{array}{l}\text { Columbia River at Beaver Army Terminal, } \\
\text { near Quincy, Oreg. }\end{array}$ & 670,049 & -- & $\mathrm{T}, \mathrm{I}$ & & na & USGS \\
\hline
\end{tabular}


- Sites were required to have a drainage area larger than 2,590 square kilometers $\left(\mathrm{km}^{2} ; 1,000\right.$ square miles $\left.\left[\mathrm{mi}^{2}\right]\right)$. The drainage areas were provided by Nancy Baker of the Nation Water-Quality Assessment Program National Monitoring and Status Assessment Team (written commun., 2013).

Some of the sites have been included in previous pesticide trend studies (table 1). The previous studies focused on streams in the U.S. Corn Belt (Sullivan and others, 2009) and urban streams (sites with greater than 25 percent of the drainage basin in urban land use and agricultural land use of no more than 25 percent; Ryberg and others, 2010). Compared to these previous studies, sites on small streams draining specific land uses are excluded and many major rivers are added, datasets have been extended in time, the periods analyzed for trends are modified to best capture the longer period of record, and a more extensive set of pesticides is analyzed. As a national geographic framework, sites are organized by hydrologic regions used for development of regional water-quality models (fig. 2).

\section{Sample Collection, Processing, and Field Quality-Control Program}

Sampling strategies varied by site and among some years, but followed guidelines established by the NAWQA Program (Crawford, 2004; Gilliom and others, 1995). Samples were collected using a combination of fixed-interval and high-flow sampling procedures. The fixed-interval sampling was more frequent during times of the year when pesticide concentrations usually were greatest, typically during the growing season. The typical frequency of sampling ranged from four times per month to once a month or once every other month, depending on the time of the year. High-flow sampling was done to target specific high streamflow events that occurred at any time during the year.

Flow-weighted, depth- and width-integrated water samples for the analysis of pesticides were collected using isokinetic samplers and processed following standard USGS methods (U.S. Geological Survey, variously dated; Shelton, 1994; Edwards and Glysson, 1999). Samples were collected from bridges, boats, or by wading. All sample-collection and processing equipment that came in contact with sample water was constructed of Teflon ${ }^{\circledR}$, glass, aluminum, or stainless steel. Equipment was cleaned with a dilute solution of phosphate-free detergent and rinsed with deionized water and pesticide-grade methanol. Water samples were filtered using pre-combusted glass-fiber filters with a nominal 0.7 -micrometer $(\mu \mathrm{m})$ pore diameter to remove suspended particulate matter and collected in baked amber glass bottles. Filtered samples were placed on ice in coolers and shipped to the National Water Quality Laboratory (NWQL) in Denver, Colorado, for pesticide analysis.

The quality of the stream-water pesticide concentration data was monitored using quality-control $(\mathrm{QC})$ procedures presented in Mueller and others (1997). The field QC program included the collection of field blank water samples to assess potential contamination, replicate water samples to assess variability, and field matrix spikes to assess bias from the analytical method, potential pesticide degradation, or matrix effects. Contamination in field blank water samples is summarized in Martin and others (1999) and has been examined and discussed within the USGS since then, with the conclusion that contamination is the same or less, but with no update to the formal report. Variability in field replicate water samples is summarized in Martin (2002). Pesticide recovery in laboratory reagent spikes and field matrix spikes is summarized in Martin and others (2009) and in Martin and Eberle (2011). The QC data are stored in the NAWQA Data Warehouse (http://cida. usgs.gov/nawqa_public/apex/f? $p=136: 1)$.

\section{Analytical Methods for Pesticides}

All water-quality samples for pesticide concentration trend analysis were analyzed by NWQL using a gas chromatography/mass spectrometry (GCMS) method. Pesticides were isolated from filtered water samples by solid-phase extraction and analyzed by capillary-column GCMS with selected-ion monitoring (Zaugg and others, 1995; Lindley and others, 1996; Madsen and others, 2003). This method is available from the National Environmental Methods Index (http://www. nemi.gov/) as USGS-NWQL method O-1126-95 (Zaugg and others, 1995). The GCMS method determines low-level concentrations of as many as 44 commonly used pesticides and 8 pesticide degradates. The pesticide fipronil and four degradates of fipronil were added to the GCMS method O-1126-02 in 1999 (Madsen and others, 2003).

The GCMS analytical method does not have specified "detection limits" for each pesticide analyte. Compounds conclusively identified (detected) by retention time and spectral characteristics are quantified and reported (Zaugg and others, 1995). Nondetections of pesticides (analyses that do not meet identification criteria based on retention time and spectral characteristics) are reported as less than the reporting level (for example, less than 0.005 micrograms per liter $[\mu \mathrm{g} / \mathrm{L}])$. The types and numerical values of reporting levels used to report nondetections of pesticides analyzed by GCMS have changed through time. Martin and Eberle (2011) provide additional information on reporting procedures for GCMS analytical data.

\section{Sources and Preparation of Concentration Data for Trend Analysis}

The sources of concentration data and the steps used to prepare the concentration data for trend analysis are explained in Martin and others (2011). The principal steps in data preparation for trend analysis were to (1) round concentrations to a consistent level of precision for the concentration range, (2) identify routine reporting levels used to report nondetections 
unaffected by matrix interference, (3) reassign the concentration value for routine nondetections to the maximum value of the long-term method detection level (maxLT-MDL), (4) adjust concentrations to compensate for temporal changes in bias of recovery of the GCMS analytical method, and (5) identify and remove samples considered inappropriate for trend analysis. In addition to the procedures used by Martin and others (2011), at selected sites with sufficient low-level pesticide detections, the concentration for routine nondetections was lowered from the maxLT-MDL to the median concentration of the low-level detections (qlow50). These data-preparation steps are further described in appendix 1.

\section{Sources and Preparation of Agricultural-use Intensity Data for Trend Analysis}

Pesticide use on a county level was estimated using a method developed by Thelin and Stone (2013) and the use estimates for 1992 through 2009 were published in Stone (2013). The county-level use estimates include two series of annual estimates, called EPest-low and EPest-high. According to Thelin and Stone (2013), EPest-low and EPest-high are two variations on their method for estimating countywide use. Both EPest-low and EPest-high "incorporated surveyed and extrapolated rates to estimate pesticide use for counties" (Thelin and Stone, 2013, p. 12). The two estimates differ in how they treat missing data for pesticide-by-crop combinations. EPest-low treats missing reports as zero use and EPest-high uses a method to estimate the use based on the use in surrounding areas (Thelin and Stone, 2013). The 2010 use estimates are considered preliminary and were derived following the same methodology and data sources (Baker and Stone, 2013). The exceptions to this method were for sites in California, SANTA, SJQUN, and SACRA (table 1), for which use estimates were obtained from annual Department of Pesticide Regulation Pesticide Use Reports (Thelin and Stone, 2013; Baker and Stone, 2013).

Annual agricultural pesticide use for each individual basin in this study was calculated by proportioning the countylevel pesticide use estimates (both EPest-low and EPest-high) to the cropland in each county for all counties contained in or overlapping the basin. For counties partially within a basin, pesticide use was equal to the proportion of cropland in the county that was contained in the basin, and was obtained using a geographic information system to overlay mapped land cover with digital maps of drainage basins and county boundaries. The annual pesticide use for each basin was divided by the basin area to obtain estimated annual use intensity (kilogram per year per square kilometer). For those basins with area outside of the United States, the annual use intensity is the agricultural use within the United States per year divided by the basin area within the United States (N.T. Baker, U.S. Geological Survey, written commun., 2013).

Annual agricultural-use intensity data for all major river basins evaluated were compiled for pesticides with agricultural uses. The compilation excluded prometon, which is not registered for use on crops; dieldrin, which was not used for agricultural purposes during this study; and all pesticide degradation products. This excluded LVWSH (table 1), a basin that had no reported agricultural uses of the pesticides in this study. Despite available agricultural-use data, ATCHF was intentionally excluded. The Atchafalaya River is used as a distributary for Mississippi River floodwaters. Therefore, at times, the pesticide concentrations in the Atchafalaya River are not representative of the agricultural uses in the Atchafalaya Basin, but of agricultural uses over a much larger area. Examples of annual agricultural-use intensity data are shown in appendix 2 .

\section{Selection of Pesticides and Periods for Trend Analysis}

Of the 52 pesticide compounds included in the USGS GCMS method described in the "Analytical Methods for Pesticides" section, 40 compounds with the highest overall rates of detection (based on initial exploratory data analysis and the data requirements for trend analysis) for the 59 major river sites were selected for trend analysis (table 2). The $40 \mathrm{com}-$ pounds are organized throughout the report by their primary use category — herbicide or insecticide (including 1 acaricide). The 40 compounds span a considerable range of registered uses and chemical properties that can affect environmental occurrence and trends, and a considerable range of relative importance among agricultural and nonagricultural applications. The EPest-high and EPest-low estimates of total annual agricultural usage in the conterminous United States for an approximate midpoint of each of the trend periods are also listed in table 2. Total usage provides readers with an indication of which pesticides were used in the greatest amount and shows differences between the EPest-high and EPest-low estimates and how they changed across the periods.

The two considerations that determined the periods for trend analysis and interpretation for each pesticide were (1) the dates for which water samples were collected and analyzed for a particular site needed to be representative of the trend period being assessed, and (2) there needed to be at least 10 uncensored concentrations (detections at or above the censoring level) for a particular site/pesticide combination. The years in which samples were collected varied considerably from site to site. Therefore, to facilitate comparisons among trends from different sites, the entire sampling interval (1992-2010) was split into three overlapping 10-year trend periods: 1992-2001, 1997-2006, and 2001-10.

The minimum sampling criteria for a particular site to be considered adequately representative of a particular 10-year trend period were to have (1) at least 10 uncensored values after recensoring (calculating qlow50 where applicable and recensoring at that level), (2) at least 5 years of samples, (3) 6 or more samples in at least 2 of the first 5 years of the period, and (4) 6 or more samples in at least 2 of the last 5 years of the period. 
Table 2. Pesticides and degradates selected for 1992-2010 major rivers trend analysis.

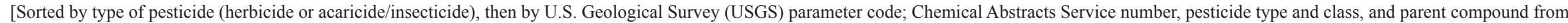
Martin and others (2011, appendix 5); year registered from U.S. Environmental Protection Agency (EPA) registration and reregistration documents (variously dated), unless otherwise noted; CAS, Chemical Abstracts Service; --, not defined or not applicable; DCPA, dimethyl tetrachloroterephthalate; DDE, dichlorodiphenyldichloroethylene; DDT, dichlorodiphenyltrichloroethane]

\begin{tabular}{|c|c|c|c|c|c|c|c|c|c|c|c|}
\hline \multirow{3}{*}{$\begin{array}{l}\text { Pesticide } \\
\text { compound } \\
\text { (synonym) }\end{array}$} & \multirow{3}{*}{$\begin{array}{l}\text { USGS } \\
\text { parameter } \\
\text { code }\end{array}$} & \multirow{3}{*}{$\begin{array}{c}\text { CAS } \\
\text { number }^{\mathrm{a}}\end{array}$} & \multirow{3}{*}{$\begin{array}{l}\text { Pesticide } \\
\text { class }\end{array}$} & \multirow{3}{*}{$\begin{array}{c}\text { Parent } \\
\text { compound, } \\
\text { if } \\
\text { degradate }\end{array}$} & \multirow{3}{*}{$\begin{array}{c}\text { Year first registered } \\
\text { as a pesticide by } \\
\text { EPA }\end{array}$} & \multicolumn{6}{|c|}{ Annual agriculural use in the conterminous United States, kilograms } \\
\hline & & & & & & \multicolumn{2}{|c|}{1997} & \multicolumn{2}{|c|}{2002} & \multicolumn{2}{|c|}{2006} \\
\hline & & & & & & $\begin{array}{l}\text { EPest-low, } \\
\text { kilograms }\end{array}$ & $\begin{array}{l}\text { EPest-high, } \\
\text { kilograms }\end{array}$ & $\begin{array}{l}\text { EPest-low, } \\
\text { kilograms }\end{array}$ & $\begin{array}{l}\text { EPest-high, } \\
\text { kilograms }\end{array}$ & $\begin{array}{l}\text { EPest-low, } \\
\text { kilograms }\end{array}$ & $\begin{array}{l}\text { EPest-high, } \\
\text { kilograms }\end{array}$ \\
\hline \multicolumn{12}{|c|}{ Herbicides and degradates } \\
\hline Propachlor & 04024 & $1918-16-7$ & acetanilide & -- & 1964 & 441,845 & $1,331,028$ & 15,087 & 101,748 & 0 & 0 \\
\hline Butylate & 04028 & $2008-41-5$ & thiocarbamate & -- & 1967 & 400,765 & $1,636,090$ & 14,344 & 64,339 & 8,451 & 39,539 \\
\hline Simazine & 04035 & $122-34-9$ & triazine & -- & 1984 & $2,472,533$ & $3,202,421$ & $2,909,245$ & $3,989,594$ & $2,184,944$ & $3,585,106$ \\
\hline Prometon & 04037 & $1610-18-0$ & triazine & -- & 1959 & -- & & -- & & -- & \\
\hline Cyanazine & 04041 & $21725-46-2$ & triazine & -- & $\begin{array}{l}1971 \text { (U.S. Environ- } \\
\text { mental Protection } \\
\text { Agency, 1984) }\end{array}$ & $9,155,963$ & $9,911,525$ & 148,644 & 535,199 & 7,489 & 35,938 \\
\hline Metolachlor & 39415 & $51218-45-2$ & acetanilide & -- & 1976 & $30,873,587$ & $32,067,021$ & $14,258,684$ & $16,964,833$ & $13,938,691$ & $16,466,859$ \\
\hline Atrazine & 39632 & $1912-24-9$ & triazine & -- & 1958 & $35,137,878$ & $36,068,664$ & $35,297,032$ & $35,977,994$ & $29,609,435$ & $30,408,210$ \\
\hline $\begin{array}{l}\text { Deethylatrazine } \\
\text { (DEA; 6-ami- } \\
\text { no-2-chloro- } \\
\text { 4-isopropyl- } \\
\text { amino-s-tri- } \\
\text { azine, CIAT) }\end{array}$ & 04040 & $6190-65-4$ & triazine & Atrazine & -- & -- & -- & -- & -- & -- & -- \\
\hline Alachlor & 46342 & $15972-60-8$ & acetanilide & -- & 1969 & $5,733,548$ & $8,612,994$ & $3,000,758$ & $5,440,781$ & $1,524,625$ & $4,020,954$ \\
\hline Acetochlor & 49260 & $34256-82-1$ & acetanilide & -- & $\begin{array}{c}1994 \text { (U.S. Environ- } \\
\text { mental Protection } \\
\text { Agency, 2006d) }\end{array}$ & $15,187,438$ & $15,906,399$ & $14,400,973$ & $14,952,957$ & $11,450,263$ & $12,380,212$ \\
\hline Metribuzin & 82630 & 21087-64-9 & triazine & -- & 1973 & $1,377,713$ & $1,655,457$ & 618,446 & 945,309 & 656,869 & 960,336 \\
\hline Trifluralin & 82661 & $1582-09-8$ & dinitroaniline & -- & 1963 & $10,710,300$ & $11,850,700$ & $5,035,407$ & $6,303,012$ & $3,290,301$ & $4,747,871$ \\
\hline Ethalfluralin & 82663 & $55283-68-6$ & dinitroaniline & -- & 1983 & $1,132,325$ & $1,475,893$ & 754,788 & 982,864 & 642,921 & 790,721 \\
\hline Terbacil & 82665 & $5902-51-2$ & uracil & -- & 1966 & 25,734 & 47,326 & 18,788 & 83,737 & 25,755 & 237,106 \\
\hline Linuron & 82666 & $330-55-2$ & urea & -- & 1966 & 372,590 & 772,010 & 187,073 & 453,511 & 111,738 & 234,371 \\
\hline $\begin{array}{l}\text { EPTC (S-Ethyl } \\
\text { dipropylthio- } \\
\text { carbamate) }\end{array}$ & 82668 & $759-94-4$ & thiocarbamate & -- & 1958 & $3,815,341$ & $5,765,527$ & $1,940,454$ & $4,394,307$ & $1,035,919$ & $1,781,545$ \\
\hline Pebulate & 82669 & $1114-71-2$ & thiocarbamate & -- & 1961 & 180,588 & 260,447 & 49,643 & 104,711 & 2,249 & 9,158 \\
\hline Tebuthiuron & 82670 & $34014-18-1$ & urea & -- & 1974 & 11,153 & 95,230 & 9,536 & 33,379 & 14,909 & 33,478 \\
\hline
\end{tabular}




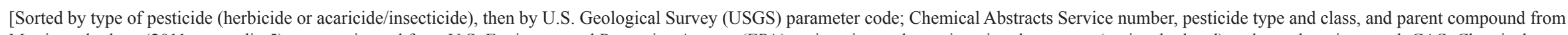
Martin and others (2011, appendix 5); year registered from U.S. Environmental Protection Agency (EPA) registration and reregistration documents (variously dated), unless otherwise noted; CAS, Chemical Abstracts Service; --, not defined or not applicable; DCPA, dimethyl tetrachloroterephthalate; DDE, dichlorodiphenyldichloroethylene; DDT, dichlorodiphenyltrichloroethane]

\begin{tabular}{|c|c|c|c|c|c|c|c|c|c|c|c|}
\hline \multirow{3}{*}{$\begin{array}{l}\text { Pesticide } \\
\text { compound } \\
\text { (synonym) }\end{array}$} & \multirow{3}{*}{$\begin{array}{l}\text { USGS } \\
\text { parameter } \\
\text { code }\end{array}$} & \multirow{3}{*}{$\begin{array}{c}\text { CAS } \\
\text { number }^{\mathrm{a}}\end{array}$} & \multirow{3}{*}{$\begin{array}{l}\text { Pesticide } \\
\text { class }\end{array}$} & \multirow{3}{*}{$\begin{array}{c}\text { Parent } \\
\text { compound, } \\
\text { if } \\
\text { degradate }\end{array}$} & \multirow{3}{*}{$\begin{array}{c}\text { Year first registered } \\
\text { as a pesticide by } \\
\text { EPA }\end{array}$} & \multicolumn{6}{|c|}{ Annual agriculural use in the conterminous United States, kilograms } \\
\hline & & & & & & \multicolumn{2}{|c|}{1997} & \multicolumn{2}{|c|}{2002} & \multicolumn{2}{|c|}{2006} \\
\hline & & & & & & $\begin{array}{l}\text { EPest-low, } \\
\text { kilograms }\end{array}$ & $\begin{array}{l}\text { EPest-high, } \\
\text { kilograms }\end{array}$ & $\begin{array}{l}\text { EPest-low, } \\
\text { kilograms }\end{array}$ & $\begin{array}{l}\text { EPest-high, } \\
\text { kilograms }\end{array}$ & $\begin{array}{l}\text { EPest-low, } \\
\text { kilograms }\end{array}$ & $\begin{array}{l}\text { EPest-high, } \\
\text { kilograms }\end{array}$ \\
\hline \multicolumn{12}{|c|}{ Herbicides and degradates-Continued } \\
\hline Molinate & 82671 & $2212-67-1$ & thiocarbamate & -- & $\begin{array}{l}1964 \text { (University } \\
\text { of Hertfordshire, } \\
2009 \text { ) }\end{array}$ & $1,680,950$ & $1,699,332$ & 957,575 & 966,857 & 162,944 & 170,523 \\
\hline $\begin{array}{l}\text { Propyzamide } \\
\quad \text { (pronamide) }\end{array}$ & 82676 & $23950-58-5$ & amide & -- & 1972 & 86,345 & 110,884 & 67,236 & 115,525 & 70,676 & 71,140 \\
\hline Triallate & 82678 & $2303-17-5$ & thiocarbamate & -- & 1961 & $1,878,493$ & $2,689,185$ & 556,491 & 809,574 & 125,511 & 573,764 \\
\hline Propanil & 82679 & $709-98-8$ & thiocarbamate & -- & $\begin{array}{l}\text { Used in Arkansas } \\
\text { since } 1959 \\
\text { (Talbert and } \\
\text { Burgos, 2007) }\end{array}$ & $3,123,056$ & $3,174,357$ & $2,922,338$ & $2,934,715$ & $2,404,550$ & $2,421,935$ \\
\hline Thiobencarb & 82681 & $28249-77-6$ & thiocarbamate & -- & 1982 & 988,595 & $1,003,546$ & 414,968 & 433,631 & 163,545 & 193,618 \\
\hline Dacthal (DCPA) & 82682 & $1861-32-1$ & $\begin{array}{l}\text { chlorobenzoic } \\
\text { acid ester }\end{array}$ & -- & 1958 & 296,624 & 425,351 & 125,441 & 135,821 & 172,614 & 204,955 \\
\hline Pendimethalin & 82683 & $40487-42-1$ & dinitroaniline & -- & 1974 & $11,022,722$ & $13,099,578$ & $6,026,428$ & $7,405,083$ & $4,594,644$ & $6,072,390$ \\
\hline Napropamide & 82684 & $15299-99-7$ & amide & -- & 1972 & 169,124 & 208,175 & 84,335 & 105,729 & 43,506 & 67,003 \\
\hline \multicolumn{12}{|c|}{ Insecticides and degradates } \\
\hline Propargite & 82685 & $2312-35-8$ & sufite ester & -- & 1969 & $1,016,812$ & $1,436,186$ & 751,017 & $1,228,963$ & 296,331 & 425,758 \\
\hline Fonofos & 04095 & $944-22-9$ & $\begin{array}{l}\text { organothio- } \\
\text { phosphate }\end{array}$ & -- & 1967 & 197,784 & 736,150 & 210 & 210 & 0 & 0 \\
\hline p,p'-DDE & 34653 & $72-55-9$ & $\begin{array}{l}\text { organochlo- } \\
\text { rine }\end{array}$ & DDT & -- & -- & -- & -- & -- & -- & \\
\hline Chlorpyrifos & 38933 & $2921-88-2$ & $\begin{array}{l}\text { organothio- } \\
\text { phosphate }\end{array}$ & -- & 1965 & $5,122,284$ & $6,485,703$ & $3,704,847$ & $4,562,436$ & $3,335,191$ & $4,399,992$ \\
\hline $\begin{array}{c}\text { gamma-HCH } \\
\text { (lindane) }\end{array}$ & 39341 & $58-89-9$ & $\begin{array}{l}\text { organochlo- } \\
\text { rine }\end{array}$ & -- & $1940 \mathrm{~s}$ & 5,841 & 10,170 & 2,652 & 4,509 & 3,461 & 8,940 \\
\hline Dieldrin & 39381 & $60-57-1$ & cyclodiene & -- & $\begin{array}{l}\text { 1950s (Florida } \\
\text { Department of } \\
\text { Health, 2011) }\end{array}$ & -- & -- & -- & -- & -- & \\
\hline Malathion & 39532 & $121-75-5$ & $\begin{array}{l}\text { organothio- } \\
\text { phosphate }\end{array}$ & -- & 1956 & $1,209,491$ & $3,307,541$ & 498,691 & $1,142,304$ & 343,598 & $1,112,180$ \\
\hline
\end{tabular}


Table 2. Pesticides and degradates selected for 1992-2010 major rivers trend analysis. - Continued

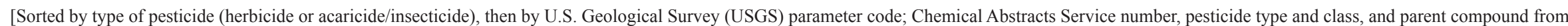
Martin and others (2011, appendix 5); year registered from U.S. Environmental Protection Agency (EPA) registration and reregistration documents (variously dated), unless otherwise noted; CAS, Chemical Abstracts Service; --, not defined or not applicable; DCPA, dimethyl tetrachloroterephthalate; DDE, dichlorodiphenyldichloroethylene; DDT, dichlorodiphenyltrichloroethane]

\begin{tabular}{|c|c|c|c|c|c|c|c|c|c|c|c|}
\hline \multirow{3}{*}{$\begin{array}{l}\text { Pesticide } \\
\text { compound } \\
\text { (synonym) }\end{array}$} & \multirow{3}{*}{$\begin{array}{l}\text { USGS } \\
\text { parameter } \\
\text { code }\end{array}$} & \multirow{3}{*}{$\begin{array}{c}\text { CAS } \\
\text { number }^{\mathrm{a}}\end{array}$} & \multirow{3}{*}{$\begin{array}{l}\text { Pesticide } \\
\text { class }\end{array}$} & \multirow{3}{*}{$\begin{array}{c}\text { Parent } \\
\text { compound, } \\
\text { if } \\
\text { degradate }\end{array}$} & \multirow{3}{*}{$\begin{array}{c}\text { Year first registered } \\
\text { as a pesticide by } \\
\text { EPA }\end{array}$} & \multicolumn{6}{|c|}{ Annual agriculural use in the conterminous United States, kilograms } \\
\hline & & & & & & \multicolumn{2}{|c|}{1997} & \multicolumn{2}{|c|}{2002} & \multicolumn{2}{|c|}{2006} \\
\hline & & & & & & $\begin{array}{l}\text { EPest-low, } \\
\text { kilograms }\end{array}$ & $\begin{array}{c}\text { EPest-high, } \\
\text { kilograms }\end{array}$ & $\begin{array}{l}\text { EPest-low, } \\
\text { kilograms }\end{array}$ & $\begin{array}{c}\text { EPest-high, } \\
\text { kilograms }\end{array}$ & $\begin{array}{l}\text { EPest-low, } \\
\text { kilograms }\end{array}$ & $\begin{array}{c}\text { EPest-high, } \\
\text { kilograms }\end{array}$ \\
\hline \multicolumn{12}{|c|}{ Insecticides and degradates-Continued } \\
\hline Diazinon & 39572 & $333-41-5$ & $\begin{array}{l}\text { organothio- } \\
\text { phosphate }\end{array}$ & -- & 1956 & 617,303 & $1,396,987$ & 366,876 & 530,610 & 259,987 & 315,204 \\
\hline Fipronil & 62166 & $\begin{array}{c}120068- \\
37-3\end{array}$ & $\begin{array}{l}\text { phenyl } \\
\text { pyrazole }\end{array}$ & -- & $\begin{array}{c}1996 \text { (U.S. Environ- } \\
\text { mental Protection } \\
\text { Agency, 1996a) }\end{array}$ & 0 & 0 & 126,073 & 190,344 & 29,313 & 62,839 \\
\hline Fipronil sulfide & 62167 & $\begin{array}{c}120067- \\
83-6\end{array}$ & $\begin{array}{l}\text { phenyl } \\
\text { pyrazole }\end{array}$ & Fipronil & -- & -- & -- & -- & -- & -- & -- \\
\hline $\begin{array}{l}\text { Desulfinylfipro- } \\
\text { nil }\end{array}$ & 62170 & -- & $\begin{array}{l}\text { phenyl } \\
\text { pyrazole }\end{array}$ & Fipronil & -- & -- & -- & -- & -- & -- & -- \\
\hline $\begin{array}{l}\text { Ethoprophos } \\
\text { (ethoprop) }\end{array}$ & 82672 & $13194-48-4$ & $\begin{array}{l}\text { organothio- } \\
\text { phosphate }\end{array}$ & -- & 1967 & 211,949 & 434,689 & 215,437 & 395,139 & 149,162 & 258,183 \\
\hline Carbofuran & 82674 & $1563-66-2$ & carbamate & -- & 1969 & $1,184,296$ & $1,877,287$ & 361,152 & $1,078,272$ & 250,986 & $1,025,209$ \\
\hline Carbaryl & 82680 & $63-25-2$ & carbamate & -- & 1959 & $1,365,238$ & $2,817,562$ & 590,666 & $1,463,668$ & 522,924 & 924,431 \\
\hline
\end{tabular}

${ }^{a}$ This report contains CAS Registry Numbers ${ }^{\circledR}$, which is a Registered Trademark of the American Chemical Society. The CAS recommends the verification of the CAS Registry Numbers ${ }^{\circledR}$ through CAS Client Services ${ }^{\mathrm{SM}}$. 


\section{Statistical Method for Analyzing Trends in Pesticide Concentrations}

The SEAWAVE-Q model (Vecchia and others, 2008; Sullivan and others, 2009; Ryberg and Vecchia, 2013) was selected as the statistical tool for analyzing trends for this study. The SEAWAVE-Q model is a parametric regression model specifically designed for analyzing seasonal- and flowrelated variability and trends in pesticide concentrations. The model is expressed as the following:

$$
\begin{aligned}
\log C(t) & =\beta_{0}+\beta_{1} W(t)+\beta_{2} \operatorname{LTFA}(t)+\beta_{3} \operatorname{MTFA}(t) \\
& +\beta_{4} \operatorname{STFA}(t)+\beta_{5} t+\eta(t)
\end{aligned}
$$

where

$$
\begin{aligned}
& \log \text { denotes the base-10 logarithm; } \\
& C \text { is pesticide concentration, in micrograms per } \\
& \text { liter; } \\
& t \quad \text { is decimal time, in years, with respect to an } \\
& \text { arbitrary time origin; } \\
& \beta_{0,} \beta_{1 .} \beta_{5} \quad \text { are regression coefficients; } \\
& W \quad \text { is a seasonal wave representing intra-annual } \\
& \text { variability in concentration; }
\end{aligned}
$$

The seasonal wave is a dimensionless, periodic function of time with an annual cycle, similar to a mixture of sine and cosine functions often used to model seasonality in concentration data; however, the seasonal wave is better suited for modeling seasonal behavior of pesticide data than a mixture of sines and cosines. The seasonal wave is a periodic (with a period of 1 year) solution to the following differential equation (Vecchia and others, 2008):

$$
\frac{d}{d} W(t)=\lambda\left(t+s^{*}\right) \varphi W(t)
$$

where

$$
\begin{aligned}
& \frac{d}{d t} \quad \text { is the derivative with respect to time; } \\
& W \quad \text { is a seasonal wave representing intra-annual } \\
& \text { variability in concentration; } \\
& t \text { is decimal time, in years, with respect to an } \\
& \text { arbitrary time origin; } \\
& \lambda(.) \quad \text { is a pulse input function with } \lambda(\text {.) greater than } \\
& 0 \text { during specified application season(s) } \\
& \text { and } \lambda(\text {.) equal to } 0 \text { otherwise; } \\
& s * \quad \text { is a seasonal shift that determines the time at } \\
& \text { which } W \text { reaches its maximum; and }
\end{aligned}
$$

$\varphi$

$$
\begin{aligned}
& \text { is a "decay rate" corresponding with an } \\
& \text { approximate half-life of } 12 / \varphi \text { months. }
\end{aligned}
$$

As in Sullivan and others (2009), the pulse input function is selected from a menu of 14 choices with either one or two distinct application seasons (when pesticides may be transported to the stream) of lengths from 1 to 6 months and the half-life is selected from four choices $(1,2,3$, or 4 months). The half-life is referred to as a model half-life when discussing model results to distinguish it from the chemical half-life of pesticides. Thus, 56 (14 times 4) choices for the wave function are available. As described in Sullivan and others (2009), the observed concentration data were used to select the best wave function and to estimate the seasonal shift $\left(s^{*}\right)$ through a combination of graphical and maximum likelihood techniques.

Three dimensionless flow anomalies were included in the SEAWAVE-Q model to help account for flow-related variability in pesticide concentrations. The anomalies were computed using the R extension package waterData (Ryberg and Vecchia, 2012) and are based on log-transformed daily flow aggregated over various time scales. The first anomaly represented short-term (day-to-day) flow variability, and was defined as

$$
\operatorname{STFA}(t)=X(t)-X_{30}(t)
$$

where

$$
\begin{aligned}
& \text { STFA } \begin{array}{r}
\text { is the short-term flow anomaly } \\
\text { (dimensionless); }
\end{array} \\
& t \text { is time; } \\
& X(t) \begin{array}{r}
\text { is log-transformed daily flow, in cubic meters } \\
\text { per second; and }
\end{array} \\
& X_{30}(t) \quad \begin{array}{r}
\text { is the average of log-transformed daily flow } \\
\text { for } 30 \text { days up to and including time } t .
\end{array}
\end{aligned}
$$

Large positive values of STFA and associated increases in pesticide concentrations tend to occur near the beginning of a substantial rainfall-runoff or snowmelt event, whereas negative values of STFA and associated decreases in pesticide concentrations tend to occur after the event passes (Vecchia and others, 2008).

The second flow anomaly represents mid-term (30- to 365-day) flow variability and was defined as

$$
\operatorname{MTFA}(t)=X_{30}(t)-X_{365}(t)
$$

where

$$
\begin{aligned}
& \text { MTFA is the mid-term flow anomaly } \\
& \text { (dimensionless); } \\
& t \text { is time; } \\
& X_{30}(t) \quad \text { is the average of log-transformed daily flow } \\
& \text { for } 30 \text { days up to and including time } t \text {; and } \\
& X_{365}(t) \quad \text { is the average of log-transformed daily flow } \\
& \text { for } 365 \text { days up to and including time } t \text {. }
\end{aligned}
$$

The third flow variable added to the model represented long-term (greater than 365 days) flow variability and was defined as 


$$
\operatorname{LTFA}(t)=X_{365}(t)-X_{*}
$$

where

$$
\begin{aligned}
\text { LTFA } & \text { is the long-term flow anomaly } \\
& \text { (dimensionless); } \\
t & \text { is time; } \\
X_{365}(t) & \text { is the average of log-transformed daily flow } \\
& \text { for } 365 \text { days up to and including time } t ; \\
& \text { and } \\
X_{*} \quad & \text { is the average of log-transformed daily flow } \\
& \text { for the specified trend period (1992-2001, } \\
& \text { 1997-2006, or 2001-10). }
\end{aligned}
$$

Unlike STFA, which tends to affect pesticide concentrations in a relatively consistent manner among different sites and pesticides, MTFA and LTFA can affect pesticide concentrations in different ways and to different degrees depending on the type of pesticide, the size of the basin, and the climatic and hydrologic properties of the basin. For example, for a relatively large basin with substantial nonurban or nonagricultural runoff, higher-than-normal seasonal flow conditions (as indicated by a positive value for LTFA) can cause decreased pesticide concentrations because of more dilution from runoff in areas where pesticides are not used (Sullivan and others, 2009).

The SEAWAVE-Q model (eq. 1) was fitted to the pesticide data using maximum likelihood methods for censored data, as described in Sullivan and others (2009), using the statistical software R (R Development Core Team, 2013) and the R extension package seawaveQ (Ryberg and Vecchia, 2013).

Statistical significance was determined using the t-test (Neter and others, 1996) of significance of the model coefficients, $\left(\beta_{1}-\beta_{5}\right.$, eq. 1). A $p$-value greater than or equal to 0.10 indicated that a model variable or trend was not statistically significant. A $p$-value less than 0.10 indicated a statistically significant model variable or an upward or downward trend (also referred to as uptrend or downtrend).

\section{Statistical Method for Analyzing Trends in Agricultural Use}

Both the EPest-low and EPest-high series for agricultural use were considered for calculating use intensity trends (appendix 2). The EPest-low, in particular, is problematic for trend analysis because of the numerous years in which pesticide/crop combinations have zero reported use. Zero use in some cases seems unlikely given the crops grown in the basin and the estimates in the years immediately preceding and following the zero estimates. In addition, the trend model used is based on the logarithm of use intensity and, therefore, zero values cannot be used. Treating the zeroes as missing values was considered; however, with annual use intensity estimates from 1992 to 2010 only, the number of observations is already small and reducing the number resulted in many series too short for reliable trend analysis. For these reasons, only those period/site/pesticide combinations with no zero values for either EPest-low or EPest-high were used for trend analysis.

The same periods were used for the use intensity trends as for the concentration trends. The statistical analysis of agricultural-use trends followed the method of Vecchia and others (2009), where trends in agricultural use for each period/ site/pesticide combination were obtained by linear regression with log-transformed annual use intensity as the dependent variable and the year as the independent variable,

$$
\log U I(t)=\beta_{0}+\beta_{1} t+\varepsilon(t)
$$

where

$U I(t)$ is the estimate of pesticide use intensity (kilogram per year per square kilometer ) for the site/pesticide combination for the year $t$,

$\beta_{0}$ and $\beta_{1} \quad$ are regression coefficients, and

$\varepsilon(t) \quad$ is the model error for the year $t$.

Because there were two estimates of pesticide usage for this study, EPest-high and EPest-low, interval-censored regression was used to incorporate both of the estimates. When the EPest-high and EPest-low estimates differed, the value used in the regression model was an interval, censored between the two estimates (each interval representing EPest-high and EPest-low for an individual year from 1992 through 2010). When the two estimates were the same, a single, noncensored value was used in the regression model. A parametric survival regression model was fit using maximum likelihood methods for censored data, using the statistical software $\mathrm{R}$ and the survival package for R (R Development Core Team, 2013; Therneau, 2013). In a small number of cases, despite sufficient data, the survival regression method (Therneau, 2013) could not converge on a solution for the parameter estimates Examples showing agricultural-use intensity data and survival regression based trends are given in appendix 2.

Trends were calculated over the three overlapping trend periods 1992-2001, 1997-2006, and 2001-10, with the exceptions of acetochlor, which was not registered for use until 1994, and fipronil, which was not registered for use until 1996. The use intensity trends can be expressed as a percent change per year, $100\left(10^{\beta_{1}}-1\right)$, where $\beta_{1}$ is the trend coefficient.

\section{Use and Properties of Pesticides}

The uses (pest target, crop usage, and total amount of active ingredient used) of the pesticides in this study affect where the pesticides are documented across the United States, the timing of the highest concentrations, and interpretation of the results. The date of registration for use and, in some cases, the date of restriction or cancellation also helps explain pesticide concentrations in surface water when actual use data are not available. For example, indoor and outdoor residential uses of diazinon have been phased out and cancelled 
(U.S. Environmental Protection Agency, 2008c). Diazinon is still detected in surface water but trends in concentration have been decreasing (Ryberg and others, 2010). Another example is the importance of the date of introduction, such as for fipronil. Fipronil was first registered for use in the United States in 1996 (U.S. Environmental Protection Agency, 1996a) and the USGS analyzed samples for fipronil beginning in 1999. Therefore, fipronil trends cannot be analyzed in the first two periods in this study. In addition, fipronil is one of the replacement insecticides for diazinon and the dates of phase out and cancellation of diazinon can be important for understanding usage of fipronil. The year each pesticide was first registered for use by the U.S. Environmental Protection Agency (EPA) is provided in table 2.

Total conterminous U.S. agricultural use for each pesticide by year and crop is shown in figure 3 . The use is the EPesthigh estimate of Thelin and Stone (2013) and the county-level data are available in Stone (2013) and Baker and Stone (2013). Additional agricultural-use estimate bar plots, with more recent data, along with the same plots for EPest-low and pesticide use maps, may be accessed online at https://water.usgs.gov/nawqa/ pnsp/usage/maps/.

In addition to the amounts used and the timing and distribution of application, the properties of pesticide compounds also affect their transport and concentrations in surface water. The soil organic carbon-water partition coefficient, water solubility, Henry's law constant, and half-life for each pesticide and degradate, when available, are listed in table 3 . The guidelines for classifying these properties affecting the transport and fate of pesticides and degradates are provided in table 4.

The logarithm of the soil organic carbon-water coefficient $\left(\mathrm{K}_{\mathrm{oc}}\right)$ indicates the tendency of each pesticide compound to sorb, or adhere, to the organic part of soil or sediment. Pesticides with a relatively low $\log K_{o c}$ have weak adsorption to soil and can move to groundwater and surface water in dissolved form. Pesticides with relatively high $\log K_{o c}$ readily sorb to soil and sediment and are less mobile in water than those with a low coefficient (U.S. Environmental Protection Agency, 2012).

Solubility in water, $\mathrm{S}_{\mathrm{w}}$, is a measure of how much of a chemical (in milligrams) will dissolve in 1 liter of water. Relatively high values of $S_{w}$ indicate that the chemical is likely to partition to water (as opposed to air and soil; U.S. Environmental Protection Agency, 2012). High solubility increases exposure potential for aquatic life and for humans through drinking water. Low solubility tends to increase the potential for bioaccumulation of the chemical (U.S. Environmental Protection Agency, 2012).

Henry's Law Constant $\left(\mathrm{K}_{\mathrm{H}}\right)$ is the ratio of a chemical concentration in the air (vapor/gas phase) to the concentration dissolved in water (aqueous phase) at equilibrium in a closed system. Like $\mathrm{S}_{\mathrm{w}}$, the logarithm of $\mathrm{K}_{\mathrm{H}}$ gives an indication of environmental partitioning - whether the pesticide or degradate is likely to volatize from water to air, or dissolve into water from air (U.S. Environmental Protection Agency, 2012).

Half-life in soil and water represents the typical time to reduce the concentration of a chemical to 50 percent of the initial concentration and is a measure of environmental persistence. These processes are $\mathrm{pH}$ sensitive and reported values may vary depending on $\mathrm{pH}$ level, soil type, and whether the value is from a field or laboratory study or is a mean of field and laboratory studies (U.S. Environmental Protection Agency, 2012; University of Hertfordshire, 2013).

\section{Trend Results}

Trends were calculated for all period/site/pesticide combinations, referred to as cases, for which there were sufficient data. Out of 7,080 possible concentration trend cases ( 3 periods x 59 sites $x 40$ pesticides and degradates), there were adequate data to evaluate trends for 1,003 concentration trends ( 779 herbicide concentration trends and 224 insecticide concentration trends). Out of 5,985 possible agricultural-use trend cases ( 3 periods $x 57$ sites $x 35$ pesticides), there were adequate data for the interval regression procedure to find a solution for 2,413 use trends $(1,749$ herbicide use trends and 664 insecticide use trends). Trend results for concentrations and use are provided in online Microsoft Excel ${ }^{\mathrm{TM}}$ files, table 5 (available at http://pubs.usgs.gov/sir/2014/5135/downloads/table05. $x l s x$ ) for herbicides and table 6 (available at $h t t p: / / p u b s . u s g s$. gov/sir/2014/5135/downloads/table06.xlsx) for insecticides. By providing the tables online, readers of this report can use the software's filters and tools to make their own detailed comparisons.

In addition to the trend results and their associated $p$-values, tables 5 and 6 provide the 90th percentile of modeled pesticide concentration for each case where a concentration trend was assessed and the modeled use intensity at the midpoint of each period. The 90th percentile for pesticide concentrations is an estimate of the concentration that is exceeded 10 percent of the time (about 36 days) in a "typical" year. The modeled 90th percentile was chosen over using a percentile from the samples because the sample percentiles are affected by the annual frequency and timing of the water-quality sampling. Because the samples do not represent a random sampling of days within each year, the sample percentiles cannot be directly related to any particular duration of exceedance. The modeled use intensity was chosen over an average value from the agricultural-use intensity data because the modeled use intensity reflects information obtained from both the EPesthigh and EPest-low estimates.

Results are provided for varying subsets of sites for each pesticide compound, for each of the three periods, depending on the adequacy of data for trend analysis. This inconsistency in periods/sites exists because sampling strategies have varied over the period of record and because of pesticide use and regulation changes. For example, cyanazine use was cancelled in 1999 and sales of existing stocks allowed through 2002 (U.S. Environmental Protection Agency, 2000). By the third period (2000-10), there were sufficient cyanazine detections for trend analysis at only two sites. 
Herbicides
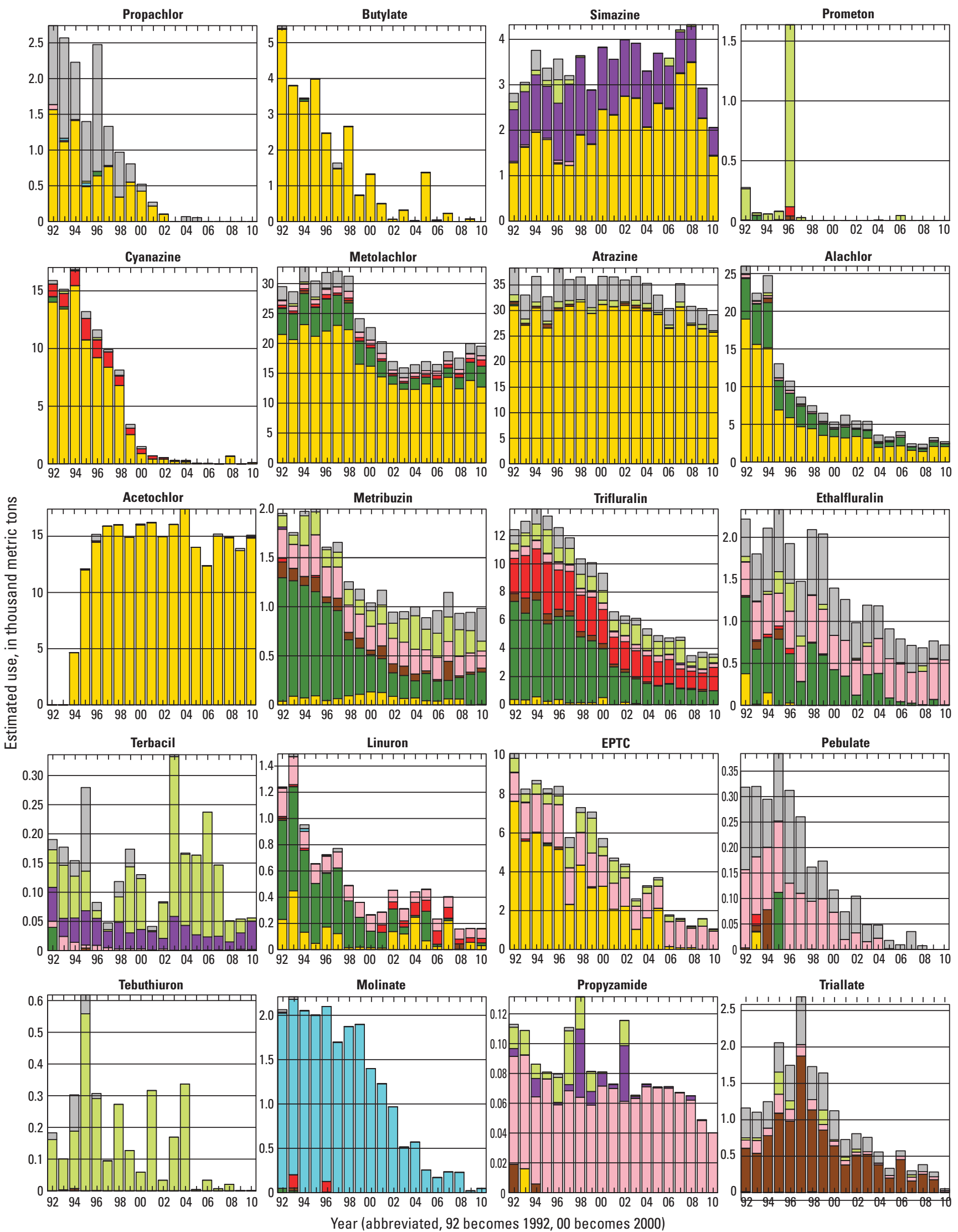

Figure 3. Total conterminous U.S. agricultural use for herbicides and insecticides by year and crop, 1992-2010. The use is the EPesthigh estimate of Thelin and Stone (2013) and the county-level data are available in Stone (2013) and Baker and Stone (2013). 


\section{Herbicides continued}
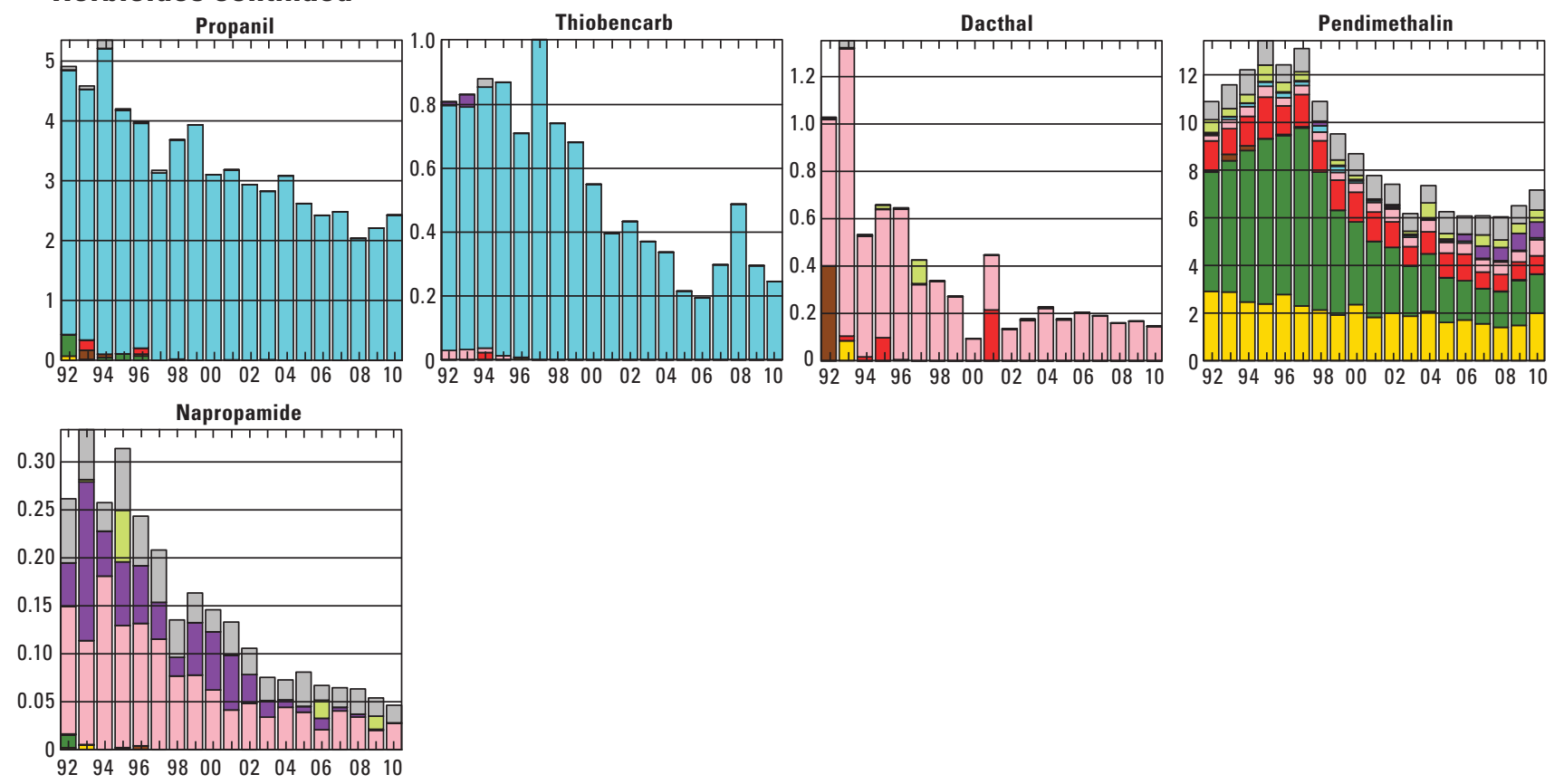

\section{Insecticides}
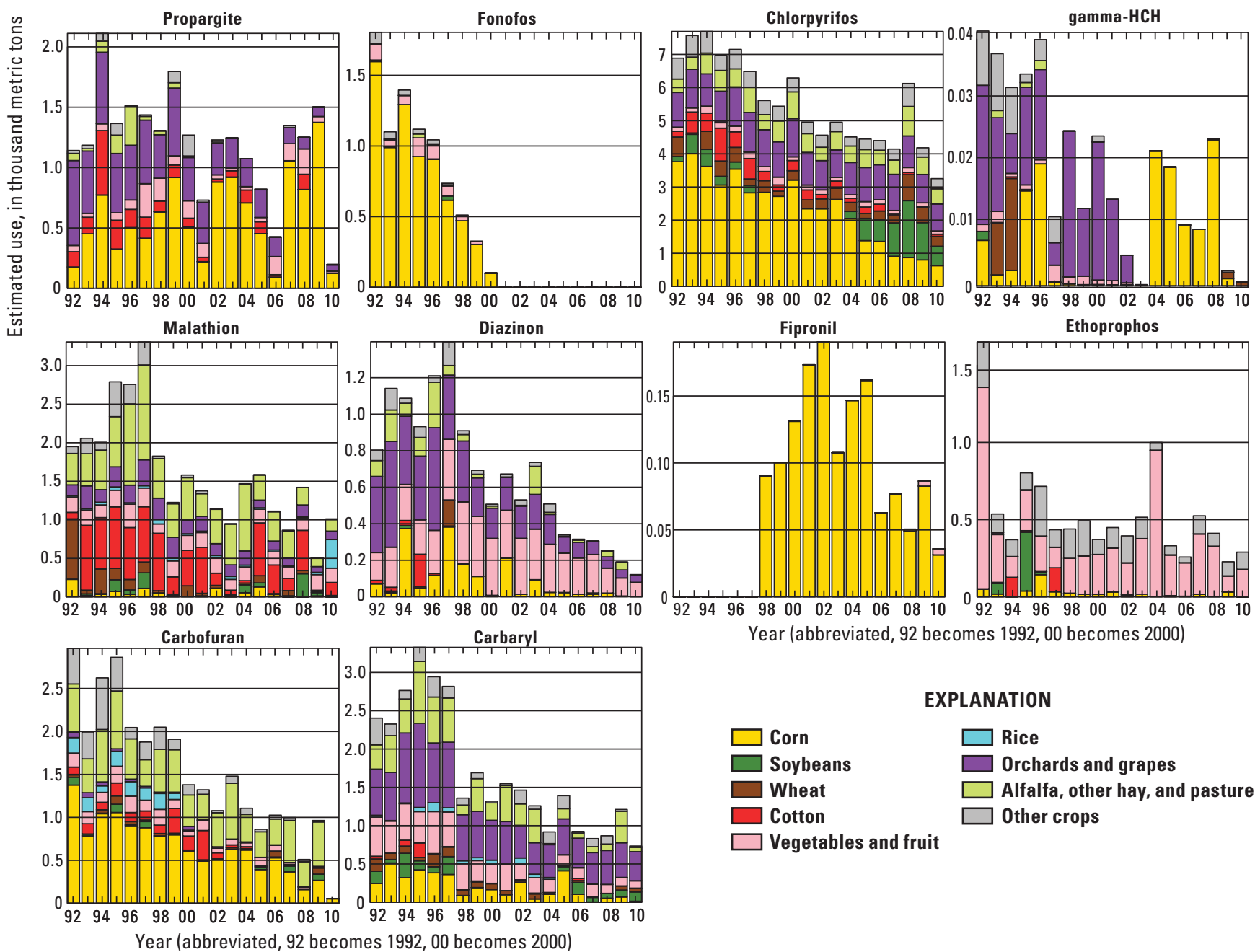

\section{EXPLANATION}

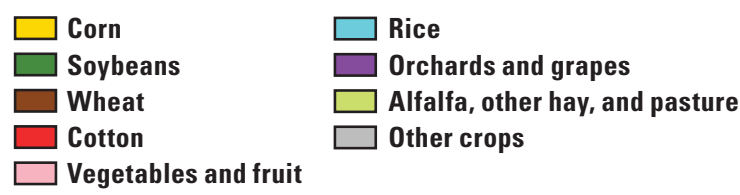

Figure 3. Total conterminous U.S. agricultural use for herbicides and insecticides by year and crop, 1992-2010. The use is the EPesthigh estimate of Thelin and Stone (2013) and the county-level data are available in Stone (2013) and Baker and Stone (2013).—Continued 
Table 3. Properties affecting the transport and fate of pesticides and degradates selected for trend analysis.

[All values obtained from Gilliom and others (2006a), unless otherwise noted; additional information about how the values in Gilliom and others (2006a) were obtained is available at http://water.usgs.gov/ nawqa/pnsp/pubs/circ1291/appendix2.html; all values measured at (or estimated for) 25 degrees Celsius $\left({ }^{\circ} \mathrm{C}\right.$ ), unless otherwise noted; numbers of significant figures are identical to those given in original sources; $\mathrm{K}_{\mathrm{OC}}$, soil organic carbon-water partition coefficient; $\mathrm{mL} / \mathrm{g}$, milliliters per gram; $\mathrm{S}_{\mathrm{w}}$, water solubility; $\mathrm{K}_{\mathrm{H}}$, Henry's law constant; Pa $\bullet \mathrm{m}^{3} / \mathrm{mol}$, pascal-cubic meters per mole; >, greater than; $\mathrm{K}_{\mathrm{d}}$, ratio of a chemical's sorbed concentration to the dissolved concentration; foc, mass fraction of soil organic carbon content; \%, percent; --, data not available; kJ/mol, kilojoules per mole; T, temperature; PPDB, Pesticide properties database (University of Hertfordshire, 2009); DT50, aerobic soil half life; EPI Suite, U.S. Environmental Protection Agency Estimation Program Interface (EPI) Suite, Version 4.0, http://www.epa. gov/oppt/exposure/pubs/episuite.htm; ARS, Agricultural Research Service; atr, atrazine]

\begin{tabular}{|c|c|c|c|c|c|c|c|c|c|c|}
\hline \multirow{3}{*}{$\begin{array}{l}\text { Pesticide } \\
\text { compound } \\
\text { (synonym) }\end{array}$} & \multirow{2}{*}{\multicolumn{2}{|c|}{$\begin{array}{c}\log K_{o c} \\
\left(K_{o c} \text { in } \mathrm{mL} / g\right)\end{array}$}} & \multirow{2}{*}{\multicolumn{2}{|c|}{$\underset{(\mathrm{mg} / \mathrm{L})}{\mathrm{S}_{\mathrm{w}}}$}} & \multirow{2}{*}{\multicolumn{2}{|c|}{$\begin{array}{c}\log K_{H} \\
\left(K_{H} \text { in } \mathrm{Pa} \cdot \mathrm{m}^{3} / \mathrm{mol}\right)\end{array}$}} & \multicolumn{4}{|c|}{ Half-life for non-photolytic transformation (days) } \\
\hline & & & & & & & \multicolumn{2}{|c|}{ In aerobic soil } & \multicolumn{2}{|c|}{ In water } \\
\hline & Value & $\begin{array}{l}\text { Source/ } \\
\text { remarks }\end{array}$ & Value & Source/remarks & Value & $\begin{array}{l}\text { Source/ } \\
\text { remarks }\end{array}$ & Value & $\begin{array}{l}\text { Source/ } \\
\text { remarks }\end{array}$ & Value & Source/remarks \\
\hline \multicolumn{11}{|c|}{ Herbicides and degradates } \\
\hline Propachlor & 1.9 & $\begin{array}{l}\text { U.S. Department of } \\
\text { Agriculture (2005) }\end{array}$ & 612 & $\begin{array}{l}\text { U.S. Department of } \\
\text { Agriculture (2005) }\end{array}$ & -1.97 & $\begin{array}{l}\text { U.S. Department of } \\
\quad \text { Agriculture (2005) }\end{array}$ & 5 & $\begin{array}{l}\text { University of Hert- } \\
\text { fordshire (2009) }\end{array}$ & 28 & $\begin{array}{l}\text { University of Hertfordshire } \\
\quad(2009) ; 20^{\circ} \mathrm{C} \text { and } \mathrm{pH} 7\end{array}$ \\
\hline Butylate & 2.48 & $\begin{array}{l}\text { U.S. Department of } \\
\quad \text { Agriculture (2005) }\end{array}$ & 44 & $\begin{array}{l}\text { U.S. Department of } \\
\quad \text { Agriculture (2005) }\end{array}$ & 0.931 & $\begin{array}{l}\text { U.S. Department of } \\
\quad \text { Agriculture (2005) }\end{array}$ & 40 & $\begin{array}{l}\text { University of Hert- } \\
\text { fordshire (2009) }\end{array}$ & $>365$ & $\begin{array}{l}\text { classified as "stable" to hydro- } \\
\text { lysis and "very persistent," } \\
\text { University of Hertfordshire } \\
\text { (2009); } 20^{\circ} \mathrm{C} \text { and pH } 7\end{array}$ \\
\hline Simazine & 2.11 & & 5 & & -3.46 & & 91 & & $>32$ & \\
\hline Prometon & 2.54 & & 750 & & -4.05 & & 932 & & $>200$ & $\begin{array}{l}\text { classified as "stable" to hydroly- } \\
\text { sis at pH 5-9 }\end{array}$ \\
\hline Cyanazine & 2.3 & $\begin{array}{l}\text { Mackay and others } \\
\text { (1997) }\end{array}$ & 171 & Mackay and others (1997) & -6.52 & $\begin{array}{l}\text { Mackay and others } \\
\text { (1997) }\end{array}$ & 17 & $\begin{array}{l}\text { U.S. Department of } \\
\quad \text { Agriculture (2005) }\end{array}$ & $>200$ & $\begin{array}{l}\text { U.S. Department of Agriculture } \\
\text { (2005); classified as "stable" } \\
\text { to hydrolysis at pH } 7,9\end{array}$ \\
\hline Metolachlor & 2.26 & & 430 & & -2.63 & & 26 & & 410 & \\
\hline Atrazine & 2.00 & & 30 & & -3.54 & & 146 & & 742 & \\
\hline $\begin{array}{l}\text { Deethylatrazine } \\
\text { (DEA; 6-ami- } \\
\text { no-2-chloro- } \\
\text { 4-isopropyl- } \\
\text { amino-s-tri- } \\
\text { azine, CIAT) }\end{array}$ & 1.90 & & 2,700 & & -4.12 & & 170 & & -- & \\
\hline Alachlor & 2.23 & $\begin{array}{l}\text { Mackay and others } \\
\text { (1997) }\end{array}$ & 240 & Mackay and others (1997) & -2.66 & $\begin{array}{l}\text { Mackay and others } \\
\text { (1997) }\end{array}$ & 20 & $\begin{array}{l}\text { U.S. Department of } \\
\quad \text { Agriculture (2005) }\end{array}$ & 640 & $\begin{array}{l}\text { Rate extrapolated to } 25^{\circ} \mathrm{C} \text { from } \\
\text { data reported by Cavalier and } \\
\text { others (1991) for alachlor } \\
\text { disappearance in groundwater } \\
(\mathrm{pH}=7.4-7.6) \text { at } 15^{\circ} \mathrm{C} \text { and } \\
22{ }^{\circ} \mathrm{C} \text {, based on the experi- } \\
\text { ment with the highest initial } \\
\text { alachlor concentration (and } \\
\text { thus maximum analytical } \\
\text { sensitivity). Value consis- } \\
\text { tent with half-life estimate } \\
\text { of "> }>100 \text { days" at } 20^{\circ} \mathrm{C} \text { in } \\
\text { deionized water reported by } \\
\text { Gan and others (2002). }\end{array}$ \\
\hline
\end{tabular}


[All values obtained from Gilliom and others (2006a), unless otherwise noted; additional information about how the values in Gilliom and others (2006a) were obtained is available at $h t t p: / / w a t e r . u s g s . g o v /$ nawqa/pnsp/pubs/circ1291/appendix2.html; all values measured at (or estimated for) 25 degrees Celsius $\left({ }^{\circ} \mathrm{C}\right.$ ), unless otherwise noted; numbers of significant figures are identical to those given in original sources; $\mathrm{K}_{\mathrm{OC}}$, soil organic carbon-water partition coefficient; $\mathrm{mL} / \mathrm{g}$, milliliters per gram; $\mathrm{S}_{\mathrm{w}}$, water solubility; $\mathrm{K}_{\mathrm{H}}$, Henry's law constant; Pa•m³/mol, pascal-cubic meters per mole; >, greater than; $\mathrm{K}_{\mathrm{d}}$, ratio of a chemical's sorbed concentration to the dissolved concentration; foc, mass fraction of soil organic carbon content; \%, percent; --, data not available; kJ/mol, kilojoules per mole; T, temperature; PPDB, Pesticide properties database (University of Hertfordshire, 2009); DT50, aerobic soil half life; EPI Suite, U.S. Environmental Protection Agency Estimation Program Interface (EPI) Suite, Version 4.0, http://www.epa. gov/oppt/exposure/pubs/episuite.htm; ARS, Agricultural Research Service; atr, atrazine]

\begin{tabular}{|c|c|c|c|c|c|c|c|c|c|c|}
\hline \multirow{3}{*}{$\begin{array}{l}\text { Pesticide } \\
\text { compound } \\
\text { (synonym) }\end{array}$} & \multirow{2}{*}{\multicolumn{2}{|c|}{$\begin{array}{c}\log K_{o c} \\
\left(K_{o c}^{\text {in }} \mathrm{mL} / \mathrm{g}\right)\end{array}$}} & \multirow{2}{*}{\multicolumn{2}{|c|}{$\underset{(\mathrm{mg} / \mathrm{L})}{\mathrm{S}_{\mathrm{w}}}$}} & \multirow{2}{*}{\multicolumn{2}{|c|}{$\begin{array}{c}\log \mathrm{K}_{\mathrm{H}} \\
\left(\mathrm{K}_{\mathrm{H}} \text { in } \mathrm{Pa} \bullet \mathrm{m}^{3} / \mathrm{mol}\right)\end{array}$}} & \multicolumn{4}{|c|}{ Half-life for non-photolytic transformation (days) } \\
\hline & & & & & & & \multicolumn{2}{|c|}{ In aerobic soil } & \multicolumn{2}{|r|}{ In water } \\
\hline & Value & $\begin{array}{l}\text { Source/ } \\
\text { remarks }\end{array}$ & Value & Source/remarks & Value & $\begin{array}{l}\text { Source/ } \\
\text { remarks }\end{array}$ & Value & $\begin{array}{l}\text { Source/ } \\
\text { remarks }\end{array}$ & Value & Source/remarks \\
\hline \multicolumn{11}{|c|}{ Herbicides and degradates-Continued } \\
\hline Acetochlor & 2.498 & $\begin{array}{l}\text { U.S. Environmental } \\
\text { Protection Agency } \\
\text { (1994a); median } \\
\text { among six values, } \\
\text { calculated from } \mathrm{K}_{\mathrm{oc}} \\
=\mathrm{K}_{\mathrm{d}} / \text { foc, where } \\
\text { foc }=(\% \mathrm{OM} / 100 \%) / \\
1.724(\text { Hamaker and } \\
\text { Thompson, 1972) }\end{array}$ & 223 & $\begin{array}{l}\text { Shiu and others (1990), } \\
\text { from SRC PhysProp Da- } \\
\text { tabase (http://esc.syrres. } \\
\text { com/interkow/webprop. } \\
\text { exe?CAS=34256-82-1) }\end{array}$ & -2.15 & $\begin{array}{l}\text { U.S. Environmental } \\
\text { Protection Agency } \\
\text { (1994a) }\end{array}$ & 11 & $\begin{array}{l}\text { Ma and others (2004); } \\
\text { Transformation } \\
\text { rate adjusted to } 25 \\
{ }^{\circ} \mathrm{C} \text { using an Ar- } \\
\text { rhenius activation } \\
\text { energy of } 76 \mathrm{~kJ} / \\
\text { mol, computed } \\
\text { from data provided } \\
\text { by original study }\end{array}$ & -- & \\
\hline Metribuzin & 1.716 & $\begin{array}{l}\text { U.S. Department of } \\
\text { Agriculture (2005) }\end{array}$ & 1,000 & $\begin{array}{l}\text { U.S. Department of } \\
\text { Agriculture (2005); } \\
20^{\circ} \mathrm{C}\end{array}$ & -5.31 & $\begin{array}{l}\text { U.S. Department of } \\
\text { Agriculture (2005); } \\
\text { Value reported at } \\
20^{\circ} \mathrm{C}(-5.4498) \\
\text { adjusted to } 25^{\circ} \mathrm{C} \\
\text { using equation } 13 \\
\text { from Mackay and } \\
\text { others (2000), and } \\
\text { an enthalpy of va- } \\
\text { porization }(\Delta \mathrm{Hv}) \text { of } \\
46.8 \mathrm{~kJ} / \mathrm{mol} \text {, based } \\
\text { on } \mathrm{K}_{\mathrm{H}} \text { data from } \\
197 \text { compounds } \\
\text { (Staudinger and } \\
\text { Roberts 2001). }\end{array}$ & 172 & $\begin{array}{l}\text { U.S. Department of } \\
\text { Agriculture (2005) }\end{array}$ & $>200$ & $\begin{array}{l}\text { U.S. Department of Agriculture } \\
\text { (2005); classified as "stable" } \\
\text { to hydrolysis at pH 5-9 }\end{array}$ \\
\hline Trifluralin & 4.14 & & 0.5 & & 1.00 & & 169 & & $>32$ & \\
\hline Ethalfluralin & 3.71 & $\begin{array}{l}\text { U.S. Department of } \\
\text { Agriculture (2005) }\end{array}$ & 0.3 & $\begin{array}{l}\text { U.S. Department of } \\
\quad \text { Agriculture (2005) }\end{array}$ & 1.11 & $\begin{array}{l}\text { U.S. Department of } \\
\quad \text { Agriculture (2005) }\end{array}$ & 45 & $\begin{array}{l}\text { U.S. Department of } \\
\text { Agriculture (2005) }\end{array}$ & $>365$ & $\begin{array}{l}\text { classified as "stable" to hydro- } \\
\text { lysis and "very persistent," } \\
\text { University of Hertfordshire } \\
\text { (2009); } 20^{\circ} \mathrm{C} \text { and pH } 7\end{array}$ \\
\hline
\end{tabular}


Table 3. Properties affecting the transport and fate of pesticides and degradates selected for trend analysis.—Continued

[All values obtained from Gilliom and others (2006a), unless otherwise noted; additional information about how the values in Gilliom and others (2006a) were obtained is available at http://water.usgs.gov/ nawqa/pnsp/pubs/circ1291/appendix2.html; all values measured at (or estimated for) 25 degrees Celsius $\left({ }^{\circ} \mathrm{C}\right)$, unless otherwise noted; numbers of significant figures are identical to those given in original sources; $\mathrm{K}_{\mathrm{OC}}$, soil organic carbon-water partition coefficient; $\mathrm{mL} / \mathrm{g}$, milliliters per gram; $\mathrm{S}_{\mathrm{w}}$, water solubility; $\mathrm{K}_{\mathrm{H}}$, Henry's law constant; Pa $\bullet \mathrm{m}^{3} / \mathrm{mol}$, pascal-cubic meters per mole; >, greater than; $\mathrm{K}_{\mathrm{d}}$, ratio of a chemical's sorbed concentration to the dissolved concentration; foc, mass fraction of soil organic carbon content; \%, percent; --, data not available; kJ/mol, kilojoules per mole; T, temperature; PPDB, Pesticide properties database (University of Hertfordshire, 2009); DT50, aerobic soil half life; EPI Suite, U.S. Environmental Protection Agency Estimation Program Interface (EPI) Suite, Version 4.0, http://www.epa. gov/oppt/exposure/pubs/episuite.htm; ARS, Agricultural Research Service; atr, atrazine]

\begin{tabular}{|c|c|c|c|c|c|c|c|c|c|c|}
\hline \multirow{3}{*}{$\begin{array}{l}\text { Pesticide } \\
\text { compound } \\
\text { (synonym) }\end{array}$} & \multirow{2}{*}{\multicolumn{2}{|c|}{$\begin{array}{c}\log K_{o c} \\
\left(K_{o c} \text { in } \mathrm{mL} / g\right)\end{array}$}} & \multirow{2}{*}{\multicolumn{2}{|c|}{$\underset{(\mathrm{mg} / \mathrm{L})}{\mathrm{S}_{\mathrm{w}}}$}} & \multirow{2}{*}{\multicolumn{2}{|c|}{$\begin{array}{c}\log K_{H} \\
\left(K_{H} \text { in } \mathrm{Pa} \bullet \mathrm{m}^{3} / \mathrm{mol}^{\prime}\right)\end{array}$}} & \multicolumn{4}{|c|}{ Half-life for non-photolytic transformation (days) } \\
\hline & & & & & & & \multicolumn{2}{|c|}{ In aerobic soil } & \multicolumn{2}{|r|}{ In water } \\
\hline & Value & $\begin{array}{c}\text { Source/ } \\
\text { remarks }\end{array}$ & Value & Source/remarks & Value & $\begin{array}{l}\text { Source/ } \\
\text { remarks }\end{array}$ & Value & $\begin{array}{l}\text { Source/ } \\
\text { remarks }\end{array}$ & Value & Source/remarks \\
\hline \multicolumn{11}{|c|}{ Herbicides and degradates-Continued } \\
\hline Terbacil & 1.80 & $\begin{array}{l}\text { U.S. Department of } \\
\text { Agriculture (2005) }\end{array}$ & 710 & $\begin{array}{l}\text { U.S. Department of } \\
\text { Agriculture (2005) }\end{array}$ & -4.92 & $\begin{array}{l}\text { U.S. Department of } \\
\quad \text { Agriculture (2005) }\end{array}$ & 520 & $\begin{array}{l}\text { U.S. Department of } \\
\text { Agriculture (2005) }\end{array}$ & $>200$ & $\begin{array}{l}\text { U.S. Department of Agriculture } \\
\text { (2005); classified as "stable" } \\
\text { to hydrolysis }\end{array}$ \\
\hline Linuron & 2.70 & $\begin{array}{l}\text { U.S. Department of } \\
\quad \text { Agriculture (2005) }\end{array}$ & 74.8 & $\begin{array}{l}\text { U.S. Department of } \\
\text { Agriculture (2005) }\end{array}$ & -3.21 & $\begin{array}{l}\text { U.S. Department of } \\
\quad \text { Agriculture (2005) }\end{array}$ & 81 & $\begin{array}{l}\text { U.S. Department of } \\
\text { Agriculture (2005) }\end{array}$ & 1,460 & $\begin{array}{l}\text { University of Hertfordshire } \\
(2009) ; 20^{\circ} \mathrm{C} \text { and } \mathrm{pH} 7\end{array}$ \\
\hline $\begin{array}{l}\text { EPTC (S-Ethyl } \\
\text { dipropylthio- } \\
\text { carbamate) }\end{array}$ & 2.3 & $\begin{array}{l}\text { Mackay and others } \\
\text { (1997) }\end{array}$ & 370 & Mackay and others (1997) & 0.00988 & $\begin{array}{l}\text { Mackay and others } \\
\quad \text { (1997) }\end{array}$ & 7 & $\begin{array}{l}\text { Mackay and others } \\
\quad \text { (1997) }\end{array}$ & $>200$ & $\begin{array}{l}\text { U.S. Department of Agriculture } \\
\text { (2005); classified as "stable" } \\
\text { to hydrolysis }\end{array}$ \\
\hline Pebulate & 2.63 & $\begin{array}{l}\text { U.S. Department of } \\
\quad \text { Agriculture (2005) }\end{array}$ & 99.7 & $\begin{array}{l}\text { U.S. Department of } \\
\quad \text { Agriculture (2005) }\end{array}$ & 0.38 & $\begin{array}{l}\text { U.S. Department of } \\
\quad \text { Agriculture (2005) }\end{array}$ & 17.5 & $\begin{array}{l}\text { University of Hert- } \\
\text { fordshire (2009) }\end{array}$ & $>30$ & $\begin{array}{l}90 \text { percent of parent remained } \\
\text { after } 30 \text { days in laboratory } \\
\text { studies (U.S. Environmental } \\
\text { Protection Agency, 1999c). }\end{array}$ \\
\hline Tebuthiuron & 2.1 & & 2,400 & & -4.88 & & 1,050 & & $>2,700$ & \\
\hline Molinate & 1.92 & $\begin{array}{l}\text { Mackay and others } \\
\text { (1997) }\end{array}$ & 970 & Mackay and others (1997) & -0.84 & $\begin{array}{l}\text { Mackay and others } \\
\text { (1997) }\end{array}$ & 21 & $\begin{array}{l}\text { Mackay and others } \\
\text { (1997); "half-life } \\
\text { is approximately } \\
3 \text { weeks in moist } \\
\text { loam soils at 21-27 } \\
{ }^{\circ} \text { C." }\end{array}$ & $>200$ & $\begin{array}{l}\text { U.S. Department of Agriculture } \\
\text { (2005); classified as "stable" } \\
\text { to hydrolysis }\end{array}$ \\
\hline $\begin{array}{l}\text { Propyzamide } \\
\quad \text { (pronamide) }\end{array}$ & 2.87 & $\begin{array}{l}\text { U.S. Department of } \\
\text { Agriculture (2005) }\end{array}$ & 12.9 & $\begin{array}{l}\text { U.S. Department of Agri- } \\
\text { culture (2005) }\end{array}$ & -2.94 & $\begin{array}{l}\text { U.S. Department of } \\
\quad \text { Agriculture (2005) }\end{array}$ & $25-136$ & $\begin{array}{l}\text { U.S. Department of } \\
\text { Agriculture (2005) }\end{array}$ & $>200$ & $\begin{array}{l}\text { U.S. Department of Agriculture } \\
\text { (2005); classified as "stable" } \\
\text { to hydrolysis }\end{array}$ \\
\hline Triallate & 3.38 & $\begin{array}{l}\text { Mackay and others } \\
\text { (1997) }\end{array}$ & 4 & Mackay and others (1997) & 0.057 & $\begin{array}{l}\text { Mackay and others } \\
\text { (1997) }\end{array}$ & 58.3 & $\begin{array}{l}\text { PPDB; DT50 (lab), } \\
20^{\circ} \mathrm{C}\end{array}$ & - & \\
\hline Propanil & 2.60 & $\begin{array}{l}\text { U.S. Department of } \\
\quad \text { Agriculture (2005) }\end{array}$ & 130 & $\begin{array}{l}\text { U.S. Department of } \\
\quad \text { Agriculture (2005) }\end{array}$ & -3.77 & $\begin{array}{l}\text { U.S. Department of } \\
\quad \text { Agriculture (2005) }\end{array}$ & 0.5 & $\begin{array}{l}\text { U.S. Department of } \\
\text { Agriculture (2005) }\end{array}$ & $>200$ & $\begin{array}{l}\text { U.S. Department of Agriculture } \\
\text { (2005); classified as "stable" } \\
\text { to hydrolysis }\end{array}$ \\
\hline Thiobencarb & 2.95 & $\begin{array}{l}\text { U.S. Department of } \\
\text { Agriculture (2005) }\end{array}$ & 27.9 & $\begin{array}{l}\text { U.S. Department of } \\
\text { Agriculture (2005) }\end{array}$ & -1.56 & $\begin{array}{l}\text { U.S. Department of } \\
\text { Agriculture (2005) }\end{array}$ & 21.0 & $\begin{array}{l}\text { U.S. Department of } \\
\text { Agriculture (2005) }\end{array}$ & $>200$ & $\begin{array}{l}\text { U.S. Department of Agriculture } \\
\text { (2005); classified as "stable" } \\
\text { to hydrolysis }\end{array}$ \\
\hline Dacthal (DCPA) & 3.75 & & 0.5 & & -0.66 & & 16 & & $>200$ & \\
\hline Pendimethalin & 4.13 & & 0.275 & & 0.0899 & & 1,300 & & $>200$ & \\
\hline
\end{tabular}


Table 3. Properties affecting the transport and fate of pesticides and degradates selected for trend analysis.—Continued

[All values obtained from Gilliom and others (2006a), unless otherwise noted; additional information about how the values in Gilliom and others (2006a) were obtained is available at $h t t p: / / w a t e r . u s g s . g o v /$ nawqa/pnsp/pubs/circ1291/appendix2.html; all values measured at (or estimated for) 25 degrees Celsius $\left({ }^{\circ} \mathrm{C}\right.$ ), unless otherwise noted; numbers of significant figures are identical to those given in original sources; $\mathrm{K}_{\mathrm{OC}}$, soil organic carbon-water partition coefficient; $\mathrm{mL} / \mathrm{g}$, milliliters per gram; $\mathrm{S}_{\mathrm{w}}$, water solubility; $\mathrm{K}_{\mathrm{H}}$, Henry's law constant; Pa•m³/mol, pascal-cubic meters per mole; >, greater than; $\mathrm{K}_{\mathrm{d}}$, ratio of a chemical's sorbed concentration to the dissolved concentration; foc, mass fraction of soil organic carbon content; \%, percent; --, data not available; kJ/mol, kilojoules per mole; T, temperature; PPDB, Pesticide properties database (University of Hertfordshire, 2009); DT50, aerobic soil half life; EPI Suite, U.S. Environmental Protection Agency Estimation Program Interface (EPI) Suite, Version 4.0, http://www.epa. gov/oppt/exposure/pubs/episuite.htm; ARS, Agricultural Research Service; atr, atrazine]

\begin{tabular}{|c|c|c|c|c|c|c|c|c|c|c|}
\hline \multirow{3}{*}{$\begin{array}{l}\text { Pesticide } \\
\text { compound } \\
\text { (synonym) }\end{array}$} & \multirow{2}{*}{\multicolumn{2}{|c|}{$\begin{array}{c}\log K_{o c} \\
\left(K_{o c} \text { in } \mathrm{mL} / g\right)\end{array}$}} & \multirow{2}{*}{\multicolumn{2}{|c|}{$\underset{(\mathrm{mg} / \mathrm{L})}{\mathrm{S}_{\mathrm{w}}}$}} & \multirow{2}{*}{\multicolumn{2}{|c|}{$\begin{array}{c}\log K_{H} \\
\left(K_{H} \text { in } \mathrm{Pa} \bullet m^{3} / \mathrm{mol}^{\prime}\right)\end{array}$}} & \multicolumn{4}{|c|}{ Half-life for non-photolytic transformation (days) } \\
\hline & & & & & & & \multicolumn{2}{|c|}{ In aerobic soil } & \multicolumn{2}{|r|}{ In water } \\
\hline & Value & $\begin{array}{l}\text { Source/ } \\
\text { remarks }\end{array}$ & Value & Source/remarks & Value & $\begin{array}{l}\text { Source/ } \\
\text { remarks }\end{array}$ & Value & $\begin{array}{l}\text { Source/ } \\
\text { remarks }\end{array}$ & Value & Source/remarks \\
\hline \multicolumn{11}{|c|}{ Herbicides and degradates-Continued } \\
\hline Napropamide & 2.66 & $\begin{array}{l}\text { U.S. Department of } \\
\text { Agriculture (2005) }\end{array}$ & 73.8 & $\begin{array}{l}\text { U.S. Department of } \\
\text { Agriculture (2005) }\end{array}$ & -4.08 & $\begin{array}{l}\text { U.S. Department of } \\
\quad \text { Agriculture (2005) }\end{array}$ & 70 & $\begin{array}{l}\text { University of Hert- } \\
\text { fordshire (2009) }\end{array}$ & $>200$ & $\begin{array}{l}\text { U.S. Department of Agriculture } \\
\text { (2005); classified as "stable" } \\
\text { to hydrolysis }\end{array}$ \\
\hline \multicolumn{11}{|c|}{ Insecticides and degradates } \\
\hline Propargite & 4.6 & $\begin{array}{l}\text { U.S. Department of } \\
\quad \text { Agriculture (2005) }\end{array}$ & 0.6 & $\begin{array}{l}\text { U.S. Department of } \\
\text { Agriculture (2005) }\end{array}$ & -2.50 & $\begin{array}{l}\text { U.S. Department of } \\
\quad \text { Agriculture (2005) }\end{array}$ & 40 & $\begin{array}{l}\text { U.S. Department of } \\
\quad \text { Agriculture (2005) }\end{array}$ & 64.8 & $\begin{array}{l}\text { University of Hertfordshire } \\
\text { (2009); } 20^{\circ} \mathrm{C} \text { and } \mathrm{pH} 7\end{array}$ \\
\hline Fonofos & 3.28 & $\begin{array}{l}\text { U.S. Department of } \\
\text { Agriculture (2005) }\end{array}$ & 16.9 & $\begin{array}{l}\text { U.S. Department of } \\
\text { Agriculture (2005) }\end{array}$ & -0.183 & & 99 & $\begin{array}{l}\text { University of Hert- } \\
\text { fordshire (2009) }\end{array}$ & 38 & $\begin{array}{l}\text { University of Hertfordshire } \\
\text { (2009); } 20^{\circ} \mathrm{C} \text { and } \mathrm{pH} 7\end{array}$ \\
\hline $\mathrm{p}, \mathrm{p}$ '-DDE & 5 & $\begin{array}{l}\text { Mackay and others } \\
\text { (1997) }\end{array}$ & 0.04 & Mackay and others (1997) & 0.9 & $\begin{array}{l}\text { Mackay and others } \\
\text { (1997) }\end{array}$ & 5,000 & $\begin{array}{l}\text { PPDB; DT50 (field); } \\
\text { 2-15.6 years }\end{array}$ & $>44,000$ & $\begin{array}{l}\text { Wolfe and others (1977); } \\
\text { reaction rate measured in } \\
5 \% \text { acetonitrile solution, } \\
\text { extrapolated to } 27^{\circ} \mathrm{C} \text { from } \\
\text { higher temperatures, and } \\
\text { interpolated to } \mathrm{pH} \text {. }\end{array}$ \\
\hline Chlorpyrifos & 3.78 & & 0.73 & & 0.0374 & & 30.5 & & 29 & \\
\hline $\begin{array}{l}\text { gamma-HCH } \\
\text { (lindane) }\end{array}$ & 3.1 & $\begin{array}{l}\text { University of Hertford- } \\
\text { shire (2009) }\end{array}$ & 7 & $\begin{array}{l}\text { U.S. Department of } \\
\text { Agriculture (2005); } \\
20^{\circ} \mathrm{C}\end{array}$ & -0.738 & $\begin{array}{l}\text { U.S. Department of } \\
\quad \text { Agriculture (2005) }\end{array}$ & 980 & $\begin{array}{l}\text { University of Hert- } \\
\text { fordshire (2009) }\end{array}$ & 732 & $\begin{array}{l}\text { University of Hertfordshire } \\
\text { (2009) }\end{array}$ \\
\hline Dieldrin & 4.08 & & 0.17 & & 0.0492 & & 1,400 & $\begin{array}{l}\text { University of Hert- } \\
\text { fordshire (2009) }\end{array}$ & 3,830 & \\
\hline Malathion & 3.26 & & 145 & & -2.64 & & $<1$ & & 6.3 & \\
\hline Diazinon & 2.76 & & 60 & & -1.39 & & 39 & & 140 & \\
\hline Fipronil & 2.76 & $\left({ }^{\mathrm{a}}\right)$ & 2.2 & ${ }^{b}\left(\mathrm{~T}=20^{\circ} \mathrm{C}\right)$ & -10.19 & ${ }^{\mathrm{c}}\left(\mathrm{T}=24^{\circ} \mathrm{C}\right)$ & 9.72 & $\left({ }^{\mathrm{d}}\right)$ & 1390 & ${ }^{\mathrm{e}}\left(\mathrm{pH} 7.1 ; 22^{\circ} \mathrm{C}\right)$ \\
\hline Fipronil sulfide & 3.59 & $\left({ }^{\mathrm{a}}\right)$ & 0.54 & $\left({ }^{f}\right)$ & -5.99 & ${ }^{g}\left(T=24^{\circ} \mathrm{C}\right)$ & 229 & ${ }^{\mathrm{a}}\left(\mathrm{T}=20^{\circ} \mathrm{C}\right),\left({ }^{\mathrm{d}}\right)$ & -- & \\
\hline $\begin{array}{l}\text { Desulfinylfipro- } \\
\text { nil }\end{array}$ & 3.26 & $\left({ }^{\mathrm{h}}\right)$ & 2.8 & $\left({ }^{\mathrm{f}}\right)$ & -4.41 & ${ }^{\mathrm{g}}\left(\mathrm{T}=24^{\circ} \mathrm{C}\right)$ & 662 & i (T not given) & -- & \\
\hline $\begin{array}{l}\text { Ethoprophos } \\
\text { (ethoprop) }\end{array}$ & 2.02 & $\begin{array}{l}\text { U.S. Department of } \\
\quad \text { Agriculture (2005) }\end{array}$ & 843 & $\begin{array}{l}21^{\circ} \mathrm{C} \text {, U.S. Department of } \\
\text { Agriculture (2005) }\end{array}$ & -1.84 & $\begin{array}{l}\text { U.S. Department of } \\
\quad \text { Agriculture (2005) }\end{array}$ & 24 & $\begin{array}{l}\text { U.S. Department of } \\
\quad \text { Agriculture (2005) }\end{array}$ & $>365$ & $\begin{array}{l}\text { classified as "stable" to hydro- } \\
\text { lysis and "very persistent", } \\
\text { University of Hertfordshire } \\
\text { (2009); } 20^{\circ} \mathrm{C} \text { and pH } 7\end{array}$ \\
\hline
\end{tabular}


Table 3. Properties affecting the transport and fate of pesticides and degradates selected for trend analysis.—Continued

[All values obtained from Gilliom and others (2006a), unless otherwise noted; additional information about how the values in Gilliom and others (2006a) were obtained is available at http://water.usgs.gov/ nawqa/pnsp/pubs/circ1291/appendix2.html; all values measured at (or estimated for) 25 degrees Celsius $\left({ }^{\circ} \mathrm{C}\right)$, unless otherwise noted; numbers of significant figures are identical to those given in original sources; $\mathrm{K}_{\mathrm{OC}}$, soil organic carbon-water partition coefficient; $\mathrm{mL} / \mathrm{g}$, milliliters per gram; $\mathrm{S}_{\mathrm{w}}$, water solubility; $\mathrm{K}_{\mathrm{H}}$, Henry's law constant; Pa $\bullet \mathrm{m}^{3} / \mathrm{mol}$, pascal-cubic meters per mole; >, greater than; $\mathrm{K}_{\mathrm{d}}$, ratio of a chemical's sorbed concentration to the dissolved concentration; foc, mass fraction of soil organic carbon content; \%, percent; --, data not available; kJ/mol, kilojoules per mole; T, temperature; PPDB, Pesticide properties database (University of Hertfordshire, 2009); DT50, aerobic soil half life; EPI Suite, U.S. Environmental Protection Agency Estimation Program Interface (EPI) Suite, Version 4.0, http://www.epa. gov/oppt/exposure/pubs/episuite.htm; ARS, Agricultural Research Service; atr, atrazine]

\begin{tabular}{|c|c|c|c|c|c|c|c|c|c|c|}
\hline \multirow{3}{*}{$\begin{array}{l}\text { Pesticide } \\
\text { compound } \\
\text { (synonym) }\end{array}$} & \multirow{2}{*}{\multicolumn{2}{|c|}{$\begin{array}{c}\log K_{o c} \\
\left(K_{o c} \text { in } \mathrm{mL} / \mathrm{g}\right)\end{array}$}} & \multirow{2}{*}{\multicolumn{2}{|c|}{$\begin{array}{c}S_{w} \\
(m g / L)\end{array}$}} & \multirow{2}{*}{\multicolumn{2}{|c|}{$\begin{array}{c}\log K_{H} \\
\left(K_{H} \text { in } \mathrm{Pa} \bullet \mathrm{m}^{3} / \mathrm{mol}^{\prime}\right)\end{array}$}} & \multicolumn{4}{|c|}{ Half-life for non-photolytic transformation (days) } \\
\hline & & & & & & & \multicolumn{2}{|c|}{ In aerobic soil } & \multicolumn{2}{|r|}{ In water } \\
\hline & Value & $\begin{array}{l}\text { Source/ } \\
\text { remarks }\end{array}$ & Value & Source/remarks & Value & $\begin{array}{l}\text { Source/ } \\
\text { remarks }\end{array}$ & Value & $\begin{array}{l}\text { Source/ } \\
\text { remarks }\end{array}$ & Value & Source/remarks \\
\hline \multicolumn{11}{|c|}{ Insecticides and degradates-Continued } \\
\hline Carbofuran & 2.02 & $\begin{array}{l}\text { Mackay and others } \\
\text { (1997) }\end{array}$ & 351 & Mackay and others (1997) & -4.3 & $\begin{array}{l}\text { Mackay and others } \\
\text { (1997) }\end{array}$ & 11 & $\begin{array}{l}\text { U.S. Department of } \\
\quad \text { Agriculture (2005) }\end{array}$ & 289 & $\begin{array}{l}\text { U.S. Department of Agriculture } \\
(2005)\end{array}$ \\
\hline Carbaryl & 2.36 & & 120 & & -4.35 & & 17 & & 11 & \\
\hline
\end{tabular}

aVerified value from the FOOTPRINT Pesticide Properties Database (PPDB).

${ }^{\mathrm{b}}$ Tomlin, 2008; value given is the average of values measured at $\mathrm{pH} 5(1.9)$ and $9(2.4)$ at $20^{\circ} \mathrm{C}$.

"Ngim and Crosby, 2001; "Desthiofipronil" seems to be identical to desulfinylfipronil.

dMeasured in a clay loam soil (weight fraction of organic carbon, $\left.\mathrm{f}_{\mathrm{oc}}=0.0197\right)$ by Zhu and others (2004). Value for fipronil consistent with the half-life of 5 days cited by Gunasekara and others (2007).

Value for fipronil sulfide (from FOOTPRINT PPDB) was consistent with results from a study by Zhu and others (2004), who observed no discernible disappearance of the degradate over 35 days.

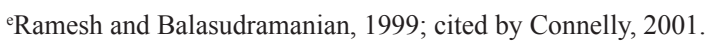

fObtained by scaling $\mathrm{S}_{\mathrm{w}}$ value measured for parent using ratio of $\mathrm{S}_{\mathrm{w}}$ values estimated for degradate and parent from octanol water partition coefficient, $\mathrm{K}_{\mathrm{ow}}$, molecular weight and structure with WsKow v.1.41, EPI (estimation program interface) Suite v.4.0.

gobtained by scaling $\mathrm{K}_{\mathrm{H}}$ value measured for parent using ratio of $\mathrm{K}_{\mathrm{H}}$ values estimated for degradate and parent from structure with HenryWin v.3.20, EPI Suite v.4.0.

hObtained by scaling Koc value reported for fipronil sulfide using the ratio of Koc values estimated from structure and $\mathrm{K}_{\text {ow }}$ for desulfinylfipronil and fipronil sulfide with KocWin v.2.00, EPI Suite v.4.0.

Resulting value is in close agreement (within 30 percent) with those from other studies cited by Gunasekara and others (2007).

'Rhône-Poulenc (1998). Value given is midpoint of range cited by Gunasekara and others, 2007 (630-693 days). 
Table 4. Property classifiers as guidelines for assessing the properties affecting the transport and fate of pesticides and degradates.

[All values for 25 degrees Celsius $\left({ }^{\circ} \mathrm{C}\right)$, unless otherwise noted; log, base-10 logarithm; $\mathrm{K}_{\mathrm{OC}}$, soil organic carbon-water partition coefficient; $\mathrm{mL} / \mathrm{g}$, milliliters per gram; >, greater than; $\leq$, less than or equal to; $\mathrm{S}_{\mathrm{w}}$, water solubility; $\mathrm{mg} / \mathrm{L}$, milligrams per liter; $\mathrm{K}_{\mathrm{H}}$, Henry's law constant; $\mathrm{Pa} \cdot \mathrm{m}^{3} / \mathrm{mol}$, pascal-cubic meters per mole]

\begin{tabular}{|c|c|}
\hline \multicolumn{2}{|c|}{ Adsorption classifications $^{1}$} \\
\hline $\log \mathrm{K}_{\mathrm{oc}}\left(\mathrm{K}_{\mathrm{oc}}\right.$ in $\left.\mathrm{mL} / \mathrm{g}\right)$ & Sorption to soil/sediment \\
\hline$>4.5$ & Very strong \\
\hline$>3.5-4.5$ & Strong \\
\hline$>2.5-3.5$ & Moderate \\
\hline$>1.5-2.5$ & Low \\
\hline$\leq 1.5$ & Negligible \\
\hline $\mathrm{S}_{\mathrm{W}}(\mathrm{mg} / \mathrm{L})$ & Solubility classifications $^{1}$ \\
\hline$>10,000$ & Very soluble \\
\hline$>1,000-10,000$ & Soluble \\
\hline$>100-1,000$ & Moderate solubility \\
\hline$>0.1-100$ & Slightly soluble \\
\hline$\leq 0.1$ & Negligible solubility \\
\hline $\log \mathrm{K}_{\mathrm{H}}\left(\mathrm{K}_{\mathrm{H}}\right.$ in $\left.\mathrm{Pa} \bullet \mathrm{m}^{3} / \mathrm{mol}\right)$ & Classification $^{1}$ \\
\hline$>-1$ & Very volatile from water \\
\hline$>-1--3$ & Volatile from water \\
\hline$>-5--3$ & Moderately volatile from water \\
\hline$>-7--5$ & Slightly volatile from water \\
\hline$\leq-7$ & Nonvolatile \\
\hline $\begin{array}{l}\text { Half-life in aerobic soil and } \\
\qquad \text { water }^{3} \text { (days) }\end{array}$ & Half-life classifications ${ }^{2}$ \\
\hline$>365$ & Very persistent \\
\hline$>100-365$ & Persistent \\
\hline$>30-100$ & Moderately persistent \\
\hline$\leq 30$ & Non-persistent \\
\hline
\end{tabular}

${ }^{1}$ Classifications obtained from U.S. Environmental Protection Agency (2012c)

${ }^{2}$ Classifications obtained from University of Hertfordshire (2013).

${ }^{3}$ Classifications for water at $20{ }^{\circ} \mathrm{C}$ and $\mathrm{pH} 7$ (University of Hertfordshire, 2013).

Of the 23 herbicides with one or more assessable trends, 13 had more than 10 assessable cases and all of these were among the 25 most frequently detected pesticides in U.S. streams and rivers, as reported by Gilliom and others (2006a). Four of the six insecticide compounds assessable for more than 10 cases were also among the most frequently detected pesticides in U.S. streams reported by Gilliom and others (2006a). The two others were fipronil and one of its degradates. Fipronil was introduced in 1996 and fipronil and its byproducts were not analyzed by the USGS laboratory until
1999 for a few sites, and 2001 for most sites. Therefore, most of the sites had insufficient data to analyze trends during the first two periods. However, during the third period (2001-10) many sites had both sufficient sampling to represent the period and high enough detection rates to analyze trends.

Many pesticide compounds that were detectable at few sites, as well as sites with few detectable pesticides, are included in tables 5 and 6 . To provide a meaningful interpretation of the patterns and causes of trends, two types of detailed graphical and numerical analyses focused on the more frequently detected pesticide compounds that had sufficient cases to evaluate. The first is a national analysis of independent, non-nested trend sites. The second is a nested basin analysis for the Mississippi River Basin, which incorporates the added information of interpreting rivers and their tributaries in relation to each other.

\section{National Analysis of Independent Trend Sites}

To provide a balanced national perspective on trends in major rivers, a subset of 39 sites was chosen to represent non-nested, relatively independent basins (hereafter called "independent trend sites") for a national analysis of pesticide and agricultural-use trends. Most of the sites excluded from this analysis are nested sites in the Midwest Region (table 1). To be included in this national analysis, an individual pesticide was required to have assessable trends for one or more sites in at least three of the five regions (fig. 2), regardless of trend period. The sites and pesticides included in the national analysis of independent trend sites are indicated by an "I" in the "Trend analyses" column of table 1 . The pesticides in this analysis include simazine, prometon, cyanazine, metolachlor, atrazine and its degradation product deethylatrazine (DEA), alachlor, tebuthiuron, Dacthal, pendimethalin, chlorpyrifos, malathion, diazinon, fipronil and its degradation product desulfinylfipronil, carbofuran, and carbaryl. All but pendimethalin were among the 25 most frequently detected pesticides in U.S. streams reported by Gilliom and others (2006a).

The concentration and agricultural-use trend results are shown graphically for each pesticide with statistically significant ( $p$-value less than 0.10) up and down trends as solid colored triangles on maps of the United States. Assessable trends that were not statistically significant ( $p$-value greater than or equal to 0.10) are shown as open triangles. Sites with insufficient data for analysis, such as highly censored or less than 10 years (intervals) of nonzero use estimates for the interval-censored regression, are also indicated on the maps (figures 4-18).

When comparing the pesticide concentration trends and the agricultural-use trends, several factors must be considered when interpreting their agreement or disagreement, including the following: 
- The use trends are for agricultural use only, whereas the concentration trends integrate all uses of the pesticides, some of which have significant nonagricultural uses;

- Pesticides that are environmentally persistent may have concentration trends that lag a decrease in use intensity;

- There may be changes in agricultural management practices (such as tillage practices or conservation buffer strips) that change the relative amount of agricultural pesticide reaching the stream, independent of the application rate;

- The agricultural-use trends are based on only 10 annual values, so there is a low power for trend detection; and

- The significance level used in the analysis is 0.10 , which means the chance of a type I error (finding a significant trend when the trend is not significant), is 10 percent, so some opposing results are expected by chance.

\section{Herbicides}

Graphical trend results for herbicides at independent trend sites are shown in figures 4-12. Trends for particular cases often could not be calculated for both concentration and agricultural use because concentration samples were not representative of a particular period, concentration was too highly censored for trend analysis, there was no reported agricultural use of pesticides (this is the case for LVWSH; table 1), there were less than 10 years of nonzero use estimates, or the interval censored regression algorithm was unable to converge to a solution for the use trends. These particular cases limit opportunities for site-by-site comparisons of concentration and agricultural-use trends.

\section{Simazine}

Simazine is a pre- or post-emergent herbicide, absorbed through leaves and roots, that selectively controls annual grasses and broadleaf weeds (U.S. Environmental Protection Agency, 2006g). Simazine concentration and agricultural-use trends are shown by site in figure 4. National agricultural use of simazine erratically increased during 1992-2010, but with use on orchards and grapes generally declining and use on corn increasing (fig. 3). Of the trend periods, use most consistently increased for corn during 1997-2006. Simazine also has many nonagricultural uses, including weed control in turfgrass, right-of-ways, industrial sites, commercial and residential lawns, and golf courses (U.S. Environmental Protection Agency, 2006g), but trends in those uses are not well known. Ryberg and others (2010) detected many significant uptrends in simazine concentration for urban streams during similar periods (1996-2004 and 2000-2008), suggesting that some nonagricultural uses have been increasing.

For 1992-2001, there were only nine sites with adequate data for concentration trend assessment, and six had significant downtrends in concentration (none had uptrends, fig. 4). Of the six sites with downtrends, none had significant downtrends in agricultural use, but all were in the western United States, where there could have been a regional change in nonagricultural use.

For 1997-2006, 32 sites had adequate data for analysis of simazine concentration trends, with 12 uptrends and 8 downtrends. Most of the uptrends were in the central United States where corn is the major crop with simazine use, and this is where four of six sites are located that also had significant uptrends in use. These results are consistent with Sullivan and others (2009), in which simazine concentrations in the Corn Belt generally increased during a similar period (1996-2006).

For the third period, 2001-10, results were generally similar to 1997-2006, but less distinct (fewer statistically significant trends). Of 24 sites with adequate concentration data, 5 had uptrends and 2 downtrends, with 3 of the uptrends at the same sites that had uptrends in the second period. During this third period, significant agricultural-use trends occurred at 8 sites and all were down.

\section{Prometon}

Prometon is a pre- or post-emergent herbicide that is nonselective and is used for total vegetation control. Prometon concentration trends are shown by site in figure 5. Prometon is not registered for use on agricultural crops, so no agriculturaluse trends are shown. Most of the significant concentration trends for 1992-2001 and 1997-2006 were downtrends (17 of 20 significant trends), except for a group of 3 significant uptrends in the southeastern United States in 1997-2006. These results are similar to Ryberg and others (2010), in which many downtrends in prometon concentrations were detected for urban sites throughout the United States during 1996-2004 (similar to the second period in this study), except for uptrends for several sites in the southeastern United States

For 2001-10, there were 20 assessable cases and prometon concentration trends were mostly nonsignificant, with 4 significant uptrends and 1 significant downtrend. Ryberg and others (2010) also found mostly nonsignificant trends with a few significant uptrends and downtrends for urban sites throughout the United States for a similar period (2000-2008).

\section{Cyanazine}

Cyanazine is notable because of its cancellation in 1999 and rapid phase out of sales through 2002 (U.S. Environmental Protection Agency, 2000), although some agricultural use is still reported (fig. 3). Cyanazine concentration and agricultural-use trends are shown by site in figure 6 . All assessable concentration and use intensity trends, whether statistically significant or not, were downward. 


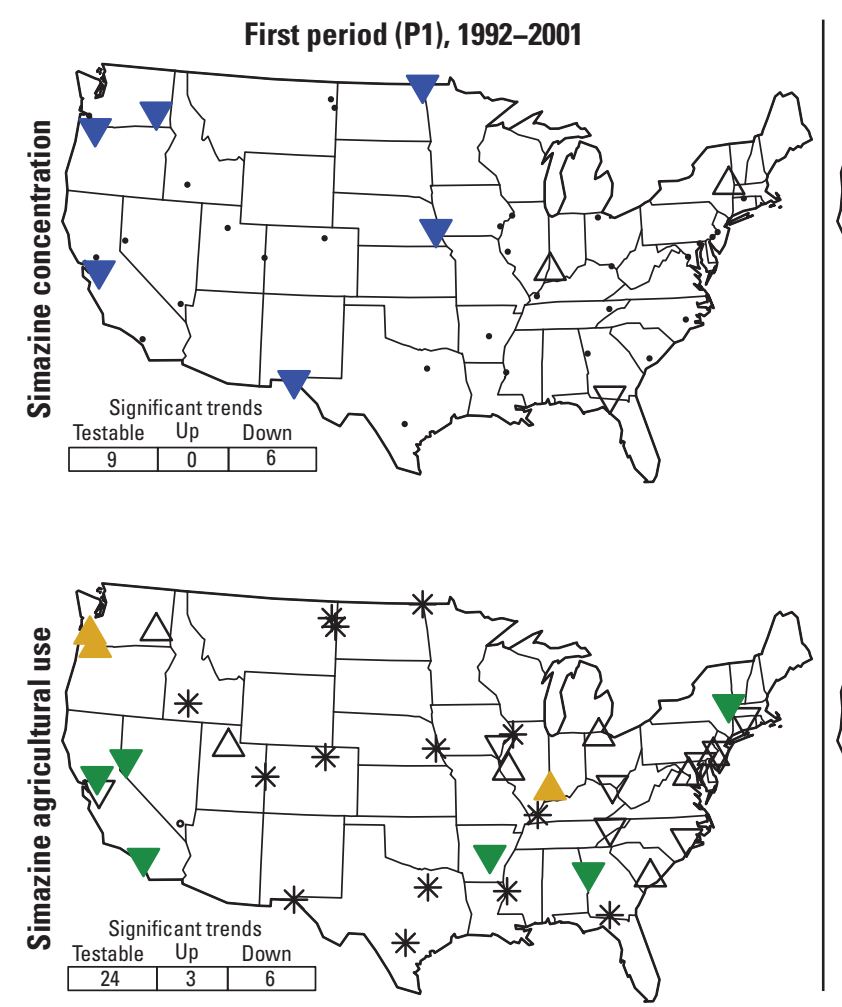

Concentration trends

$\triangle$ Uptrend

$\nabla$ Downtrend

$\triangle$ Nonsignificant, $p \geq 0.10$

$\nabla$ Nonsignificant, $p \geq 0.10$

C Too highly censored to analyze

- Samples not representative of trend period
Second period (P2), 1997-2006
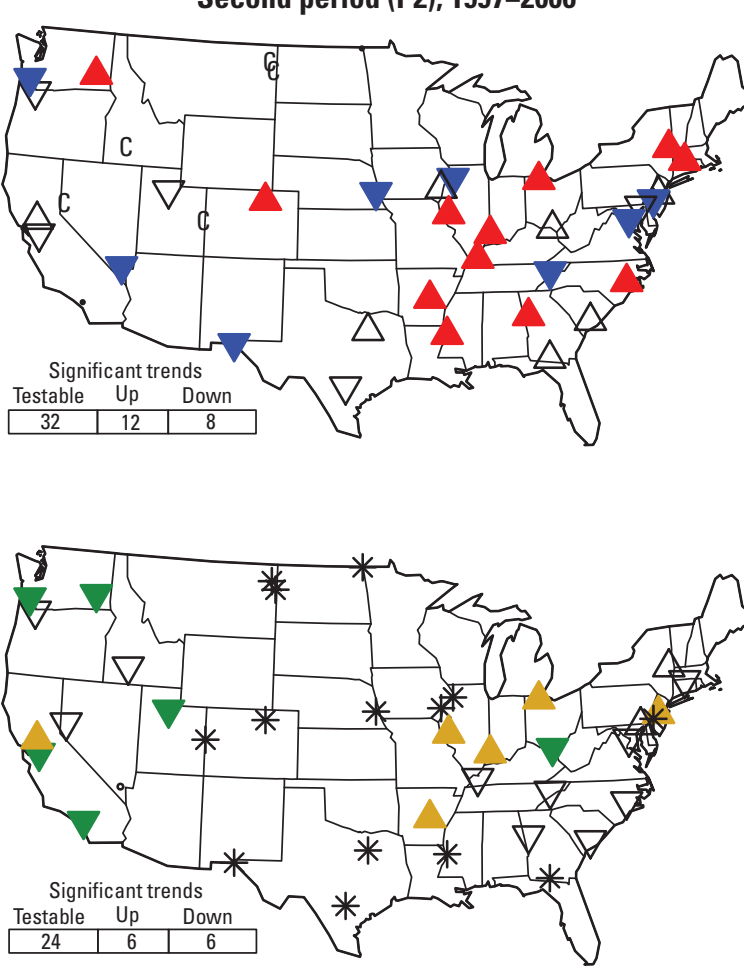

EXPLANATION

Agricultural-use trends

\section{$\triangle$ Uptrend}

$\nabla$ Downtrend

$\triangle$ Nonsignificant, $p \geq 0.10$

$\nabla$ Nonsignificant, $p \geq 0.10$

* Less than 10 years of

nonzero use estimates

or nonconvergence

- No agricultural use

\begin{tabular}{llll}
$P 1$ & $P 2$ & $P 3$ \\
\hline 5 & 21 & 16 & Bo
\end{tabular}
Third period (P3), 2001-2010
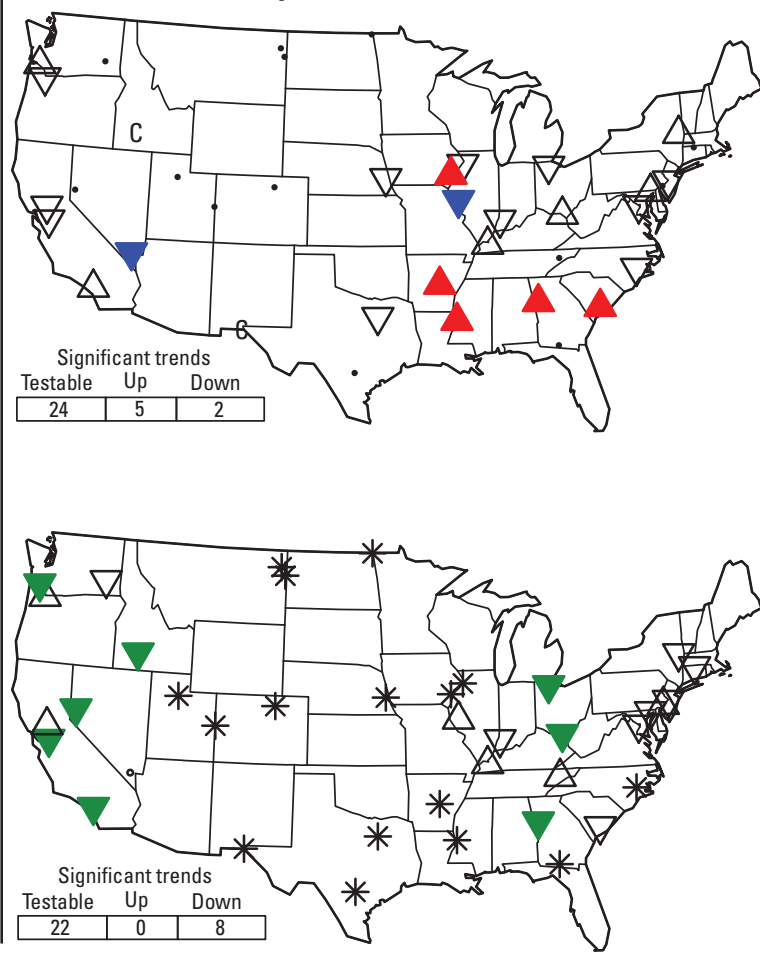

Base from maps package in $R$ (Brownrigg, 2013; $R$ Development Core Team, 2013) Eisenlohr projection

Significant concentration and us trends at matching sites

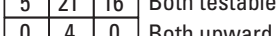

\begin{tabular}{|l|l|l|l|}
\hline 0 & 4 & 0 & Both upward \\
\hline 0 & 1 & 0 & Both downward \\
\hline 1 & 1 & 1 & Oppostent \\
\hline
\end{tabular}

\begin{tabular}{l|l|l|l}
\hline 1 & 1 & 1 & Opposite directions
\end{tabular}

$p$ Significance level

$\geq$ Greater than or equal to

Figure 4. Simazine concentration and agricultural-use trends at independent trend sites, 1992-2010. 

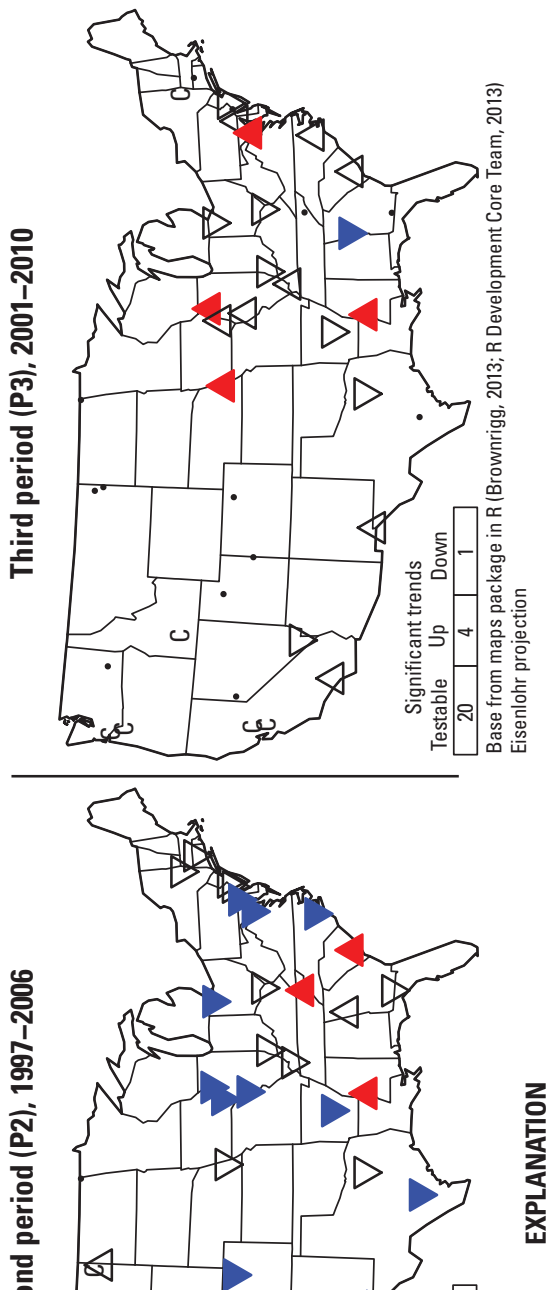

For 1992-2001, there were only 7 sites with adequate concentration data and 5 had both significant concentration and agricultural-use downtrends. A similar pattern followed for 1997-2006, for which 12 of 14 assessable sites had significant downtrends in concentrations. Agricultural-use trends were statistically unassessable for most sites during this second period, but figure 3 clearly shows the rapid decline in use during the first one-half of the period. By the third period (2001-10), there were only two assessable sites for concentration trends (because of too few detections at most sites for analysis), both with significant downtrends in concentration. No trends were assessable for agricultural use.

\section{Metolachlor}

Metolachlor is a broad-spectrum pre-emergent herbicide for general weed control (U.S. Environmental Protection Agency, 1995c). In 1996, a reformulation of metolachlor, $\mathrm{S}$-metolachlor, was introduced that resulted in effective weed control with less metolachlor (Sullivan and others, 2009). Metolachlor concentration and agricultural-use trends are shown by site in figure 7 . The agricultural use of metolachlor shown in figure 3 and used for trend analyses is the sum of metolachlor and S-metolachlor; they are both analyzed as metolachlor in chemical analyses of water samples. As S-metolachlor was phased into use, it had mostly replaced metolachlor by 2002, with total use of both forms at a combined total of about one-half the amounts used in 1996 and 1997. This reduction in use is consistent with most of the significant downtrends in concentration during the first two periods, particularly during 1997-2006.

During 1992-2001, there were eight sites with adequate data to assess concentration trends and there were three significant trends - all downward. During 1997-2006, assessable sites increased to 32 and 14 of the 20 significant concentration trends were downward, with all 14 also having significant downtrends in agricultural use (fig. 7). Of the six significant concentration uptrends during the second period, one-half had significant downtrends in agricultural use. Although there are some nonagricultural uses of metolachlor (U.S. Environmental Protection Agency, 1995c), nonagricultural use is unlikely to cause such a large discrepancy between concentration and agricultural-use trends. In fact, during a similar period (19962004), Ryberg and others (2010) found mostly downtrends in metolachlor concentration for urban sites across the United States and there were only two significant uptrends (including one of the sites, CHATT, analyzed in this study; table 1). The discrepancies in the directions of agricultural use and concentration trends may be a result of errors in use trends for basins with mixed crops in widely scattered areas and relatively low metolachlor use, coupled with high uncertainty in the concentration trends for highly censored datasets.

During 2001-10, national use of metolachlor reversed the previous decline that came with the introduction of S-metolachlor (fig. 3) and, consistent with this, there were 15 
First period (P1), 1992-2001
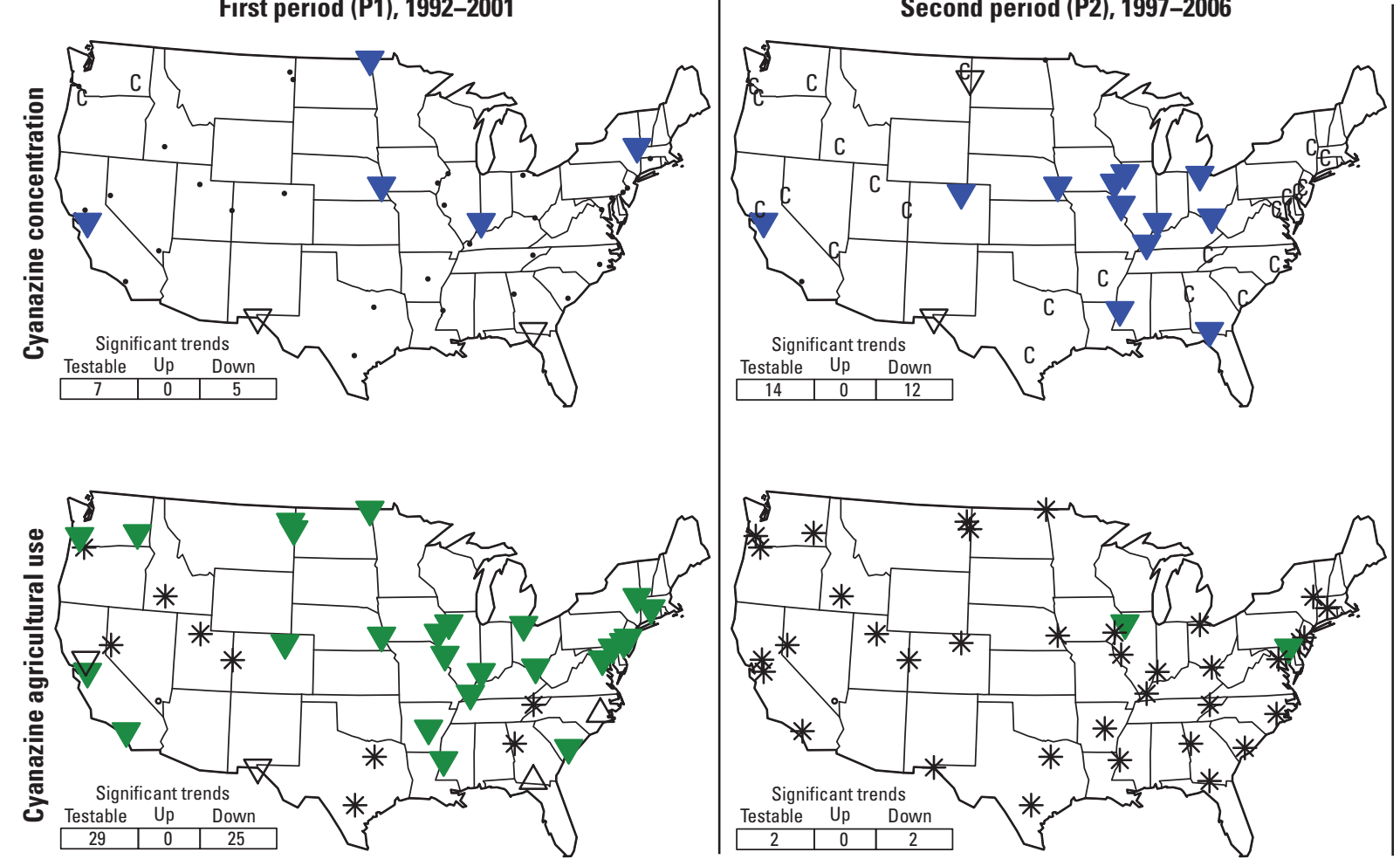

EXPLANATION
Third period (P3), 2001-2010

న
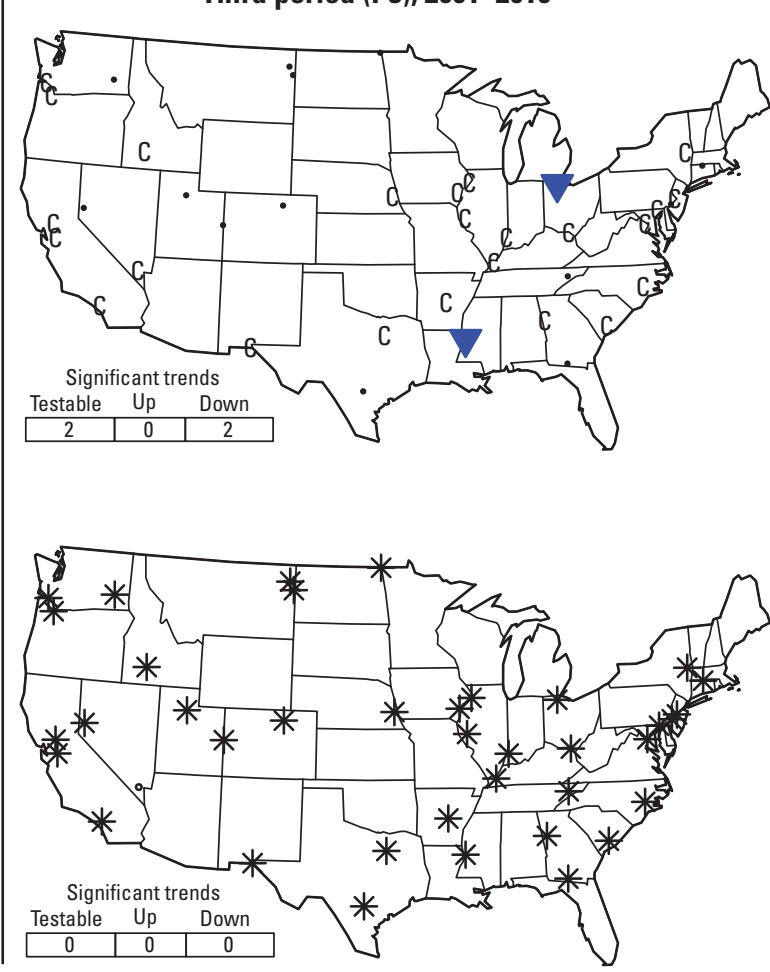

Base from maps package in R (Brownrigg, 2013; R Development Core Team, 2013) Eisenlohr projection

Concentration trends
Uptrend
Downtrend
$\triangle$ Nonsignificant, $p \geq 0.10$
$\nabla$ Nonsignificant, $p \geq 0.10$
C Too highly censored to analyze
- Samples not representative of
trend period

Agricultural-use trends Significant concentration and use

Uptrend trends at matching sites

Uptrend

$\triangle$ Nonsignificant, $p \geq 0.10$

$\nabla$ Nonsignificant, $p \geq 0.10$

* Less than 10 years of

nonzero use estimates

or nonconvergence

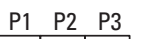

\begin{tabular}{|l|l|l|l|l|}
\hline 7 & 1 & 0 & Both testable \\
\hline 0 & 0 & 0 & Both upward \\
\hline
\end{tabular}

\begin{tabular}{|l|l|l|l|}
\hline 0 & 0 & 0 & Both upward \\
\hline 5 & 1 & 0 & Both doward \\
\hline
\end{tabular}

trend period

- No agricultural use

\begin{tabular}{|l|l|l|l}
\hline 5 & 1 & 0 & Both downward \\
\hline 0 & 0 & 0 & Opposite directions \\
\hline
\end{tabular}

$p$ Significance level

$\geq$ Greater than or equal to

Figure 6. Cyanazine concentration and agricultural-use trends at independent trend sites, 1992-2010. 


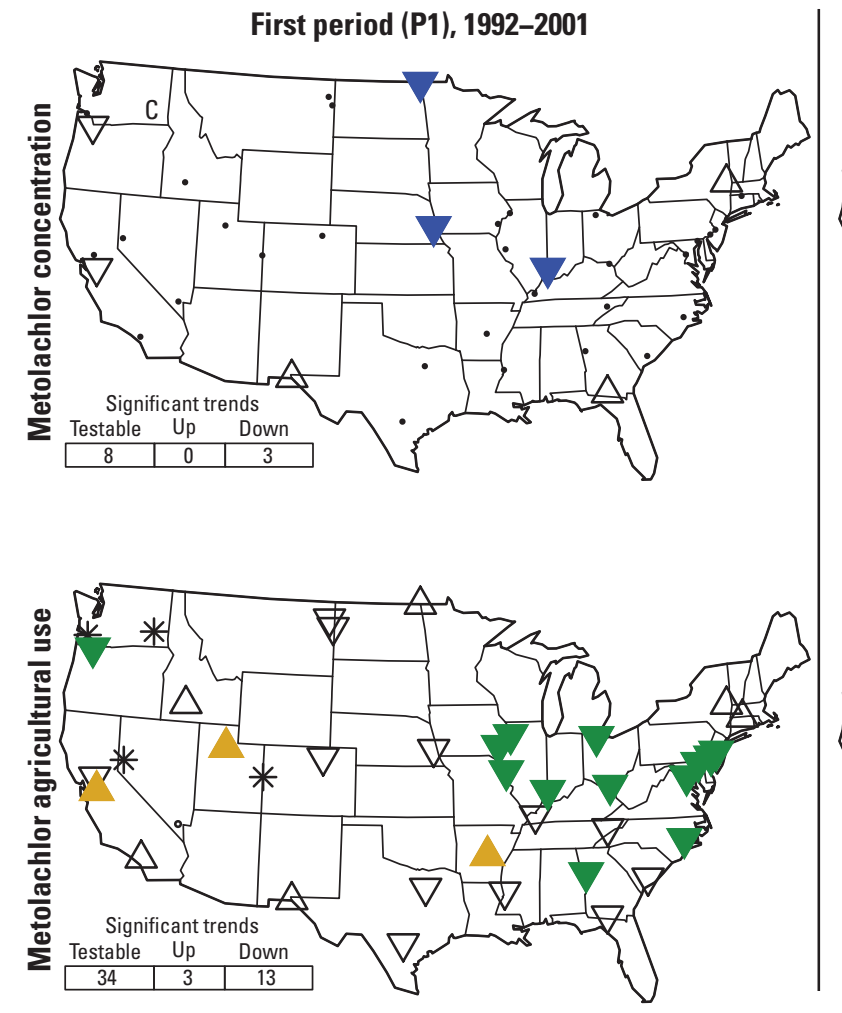

Concentration trends

\section{$\triangle$ Uptrend}

$\nabla$ Downtrend

$\triangle$ Nonsignificant, $p \geq 0.10$

$\nabla$ Nonsignificant, $p \geq 0.10$

C Too highly censored to analyze

- Samples not representative of trend period
Second period (P2), 1997-2006
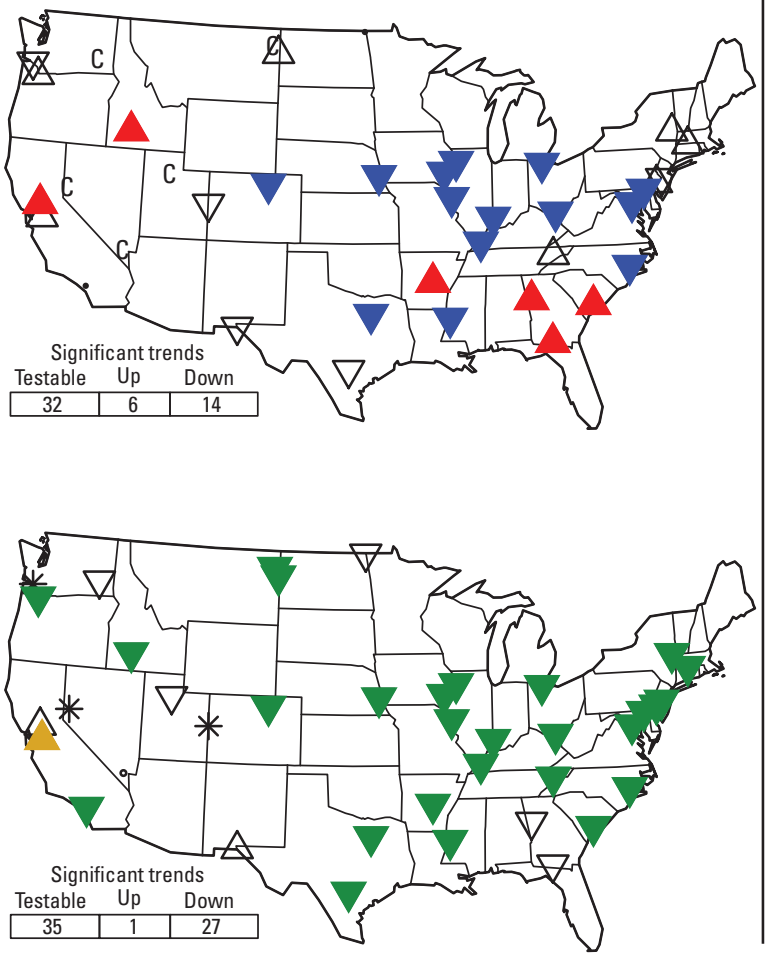

\section{EXPLANATION}

Agricultural-use trends Significant concentration and use

\section{Uptrend trends at matching sites}

$\nabla$ Downtrend

\begin{tabular}{l|l|l|l|l|} 
& Nonsignificant, $p \geq 0.10 \quad 8$ & 30 & 25 & Both testable \\
\cline { 2 - 5 } & & 0 & 0 & 2 \\
\end{tabular}

$\nabla$ Nonsignificant, $p \geq 0.10$

* Less than 10 years of

nonzero use estimates

or nonconvergence

$p$ Significance level

$\geq$ Greater than or equal to
Third period (P3), 2001-2010
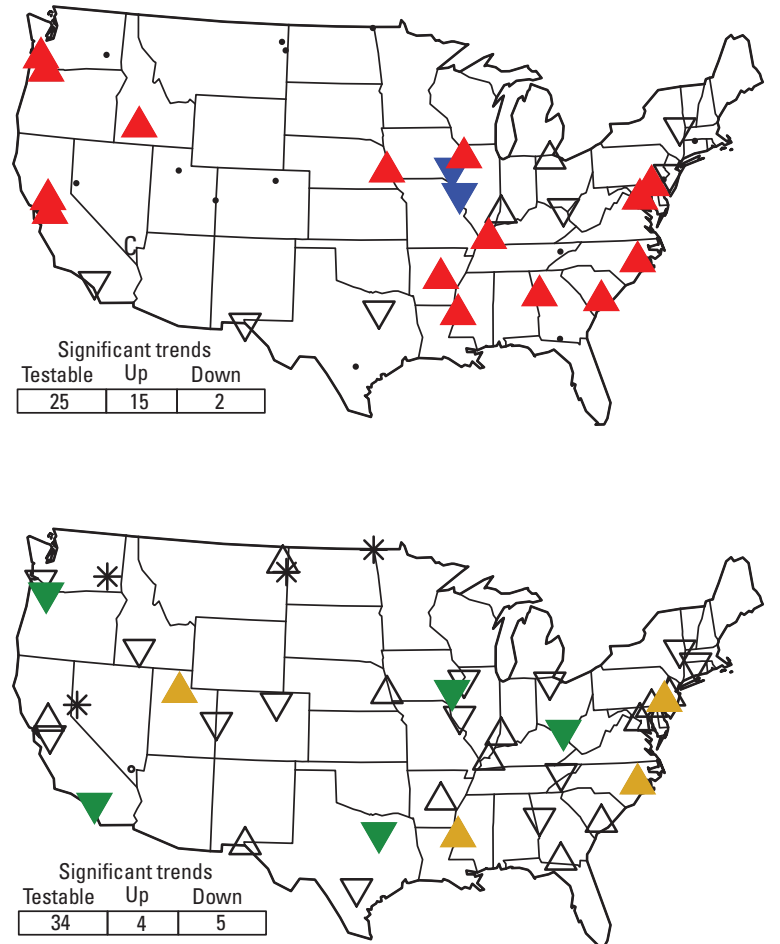

Base from maps package in $R$ (Brownrigg, 2013; R Development Core Team, 2013) senlohr projection 
significant concentration uptrends and only 2 downtrends. Of the 15 sites with uptrends, 3 also had significant uptrends in use.

\section{Atrazine and Deethylatrazine}

Atrazine is a pre- or post-emergent herbicide used to control broadleaf weeds and some grassy weeds (U.S. Environmental Protection Agency, 2006c). Atrazine is one of the most widely used agricultural pesticides in the United States and deethylatrazine (DEA) is one of its degradation products. Atrazine concentration and agricultural-use trends are shown by site in figure 8 , along with concentration trends for DEA. Atrazine use for agriculture was relatively stable during the first period and the first one-half of the second, 1992-2003, with most used on corn, but declined approximately 10 percent during 2003-10 (fig. 3). Site-by-site use trends are generally consistent with the national pattern, with 1992-2001 mixed and with no strong pattern, and both 1997-2006 and 2001-10 having mostly downtrends (among those with significant results). Trends in atrazine concentrations in rivers generally were consistent with use trends, whereas deethylatrazine, as will be discussed, had some notable differences.

For 1992-2001, nine sites had adequate atrazine data for concentration trend assessment, with one site having a significant uptrend and four with significant downtrends. Results for DEA were almost identical to atrazine for this first period, with four of five downtrends found at the same sites as atrazine and one uptrend at the same site as atrazine. For both atrazine and DEA, three of the sites with downtrends also had significant downtrends in use.

For 1997-2006, assessable sites increased to 37 for atrazine concentration and there were 14 significant downtrends and 6 significant uptrends. Seven of the downtrends also had significant use downtrends. In contrast, DEA had more uptrends than downtrends and less correspondence to atrazine use trends. This same pattern repeated during the 2001-10 period, with atrazine having more downtrends than uptrends (consistent with use trends), and with DEA having more uptrends than downtrends (inconsistent with atrazine use trends). For 2001-10, there were 8 significant downtrends in atrazine concentrations, compared to 5 significant uptrends, and there were 12 significant uptrends in DEA, compared to 1 significant downtrend.

The occurrence of uptrends in DEA concentrations for sites and periods with significant downtrends in both the use and concentrations of atrazine could be caused by some factor, such as a management practice, that has increased over time the proportion of applied atrazine that runs off to streams as DEA, or by a transport pathway for DEA, such as groundwater, that has multi-year lags between use and arrival at a stream. Gilliom and others (2006a) reported that DEA-to-atrazine ratios were generally higher in groundwater than streams, reflecting the longer periods of time spent in contact with soil for the atrazine compounds detected in the groundwater system, relative to streams, because degradation occurs with the assistance of soil microorganisms. Thus, increasing concentrations of DEA in groundwater reaching streams - resulting from high rates of past atrazine use where the groundwater originated - could explain the uptrends in some streams. Another possibility is that a management practice, such as no-till agriculture, could result in longer residence times of atrazine in soil and a greater amount of transformation to DEA before runoff to a stream. Alternatively, or in addition to, increased use of tile drains may increase the amount of stream inflow from shallow groundwater and reduce the amount from surface runoff. Additional analysis of atrazine and DEA trends for the Mississippi River Basin will be presented in the "Nested Basin Analysis" section.

\section{Alachlor}

Alachlor is a selective herbicide for control of broadleaf weeds and grasses (U.S. Environmental Protection Agency, 1998a). Most of the alachlor concentration and agriculturaluse trends that could be analyzed for all three periods are downtrends, many of which are significant (fig. 9). The steepest declines in national use were during 1992-2001, with a total reduction of about 80 percent, followed by more moderate declines during 2001-10, with a further reduction of about 50 percent (fig. 3). According to Sullivan and others (2009), alachlor use has steadily declined since 1994 because of two main factors: the introduction of acetochlor (which widely replaced alachlor for corn) and the introduction of glyphosate-resistant soybeans (reducing the need for alachlor for soybeans).

For 1992-2001, five sites had adequate data for assessing concentration trends and all five had significant downtrends, including three that also had significant downtrends in use and two with nonsignificant trends in use. For 1997-2006, there were 13 sites with adequate data. Nine had significant downtrends and eight of the nine also had downtrends in use. During 2001-10, concentration trends were less prevalent, but still mostly down (four out of five significant trends), with one of the four also having a significant downtrend in use.

\section{Tebuthiuron}

Tebuthiuron is used to control broadleaf and woody weeds, and grasses and brush on pasture, rangeland, and a variety of nonagricultural areas, such as airports, outdoor industrial areas, rights-of-way and fencerows, uncultivated soils, and under paved roads and sidewalks in areas where no future landscaping is planned (U.S. Environmental Protection Agency, 1994b). The low agricultural use, limited mainly to reported use on alfalfa, other hay, and pasture (fig. 3), resulted in insufficient data to evaluate agricultural-use trends. Estimates of typical annual use by EPA during 2000-2007 indicate that nonagricultural uses were about twice the amount of agricultural uses (Toccalino and others, 2014). Although there are no detailed data on nonagricultural-use trends, Ryberg 

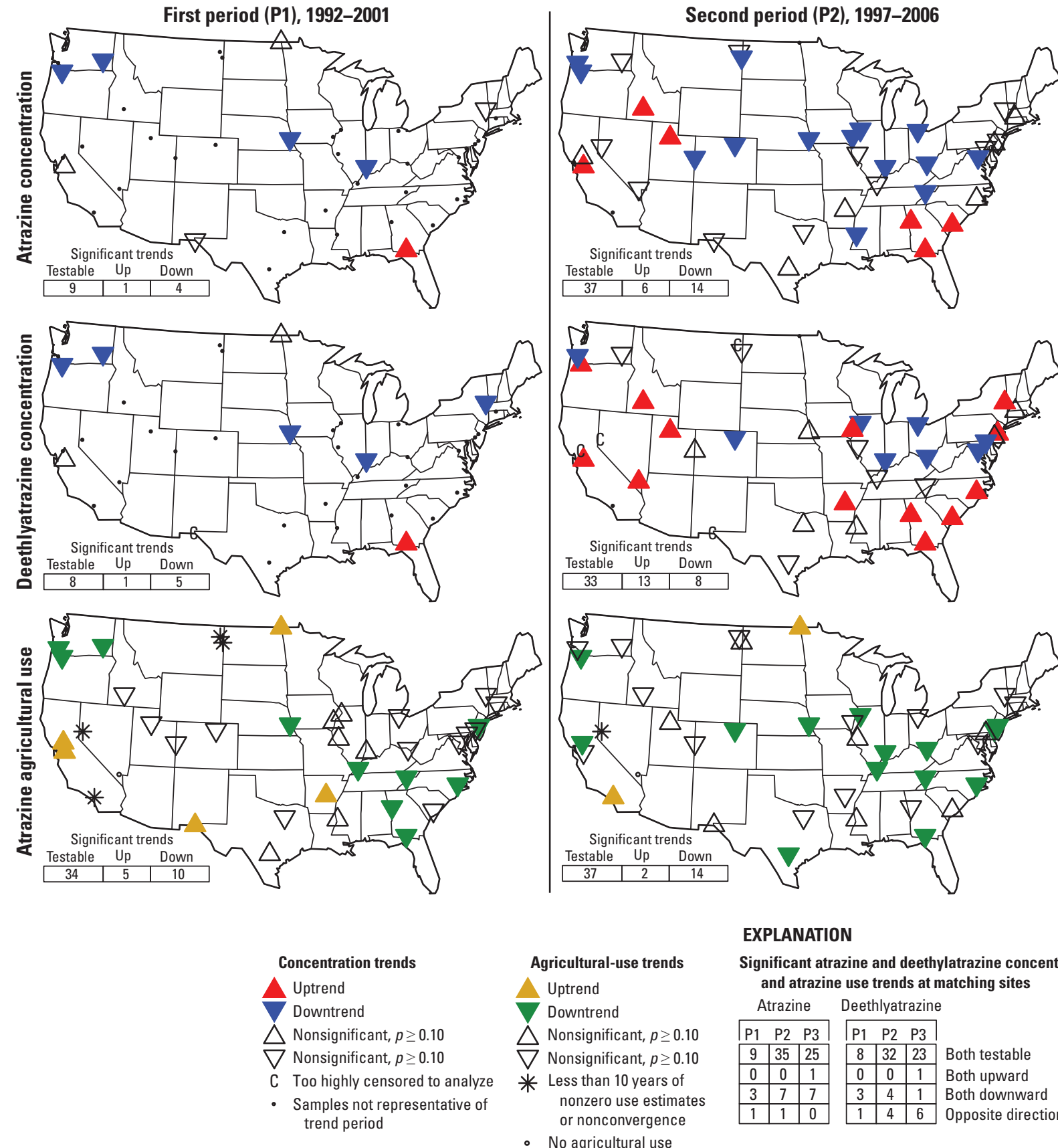

\section{EXPLANATION}

Significant atrazine and deethylatrazine concentration $\quad p$ Significance level and atrazine use trends at matching sites

$\geq$ Greater than or equal to Atrazine Deethlyatrazine

\begin{tabular}{|lll|lll|l|l|l|l|l|l|l|l|l|l|l}
\hline P1 & P2 & P3 & P2 & P3
\end{tabular}

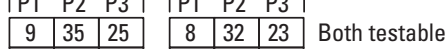

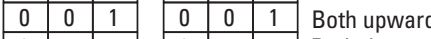

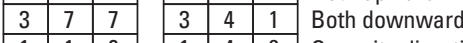

r nonconvergence
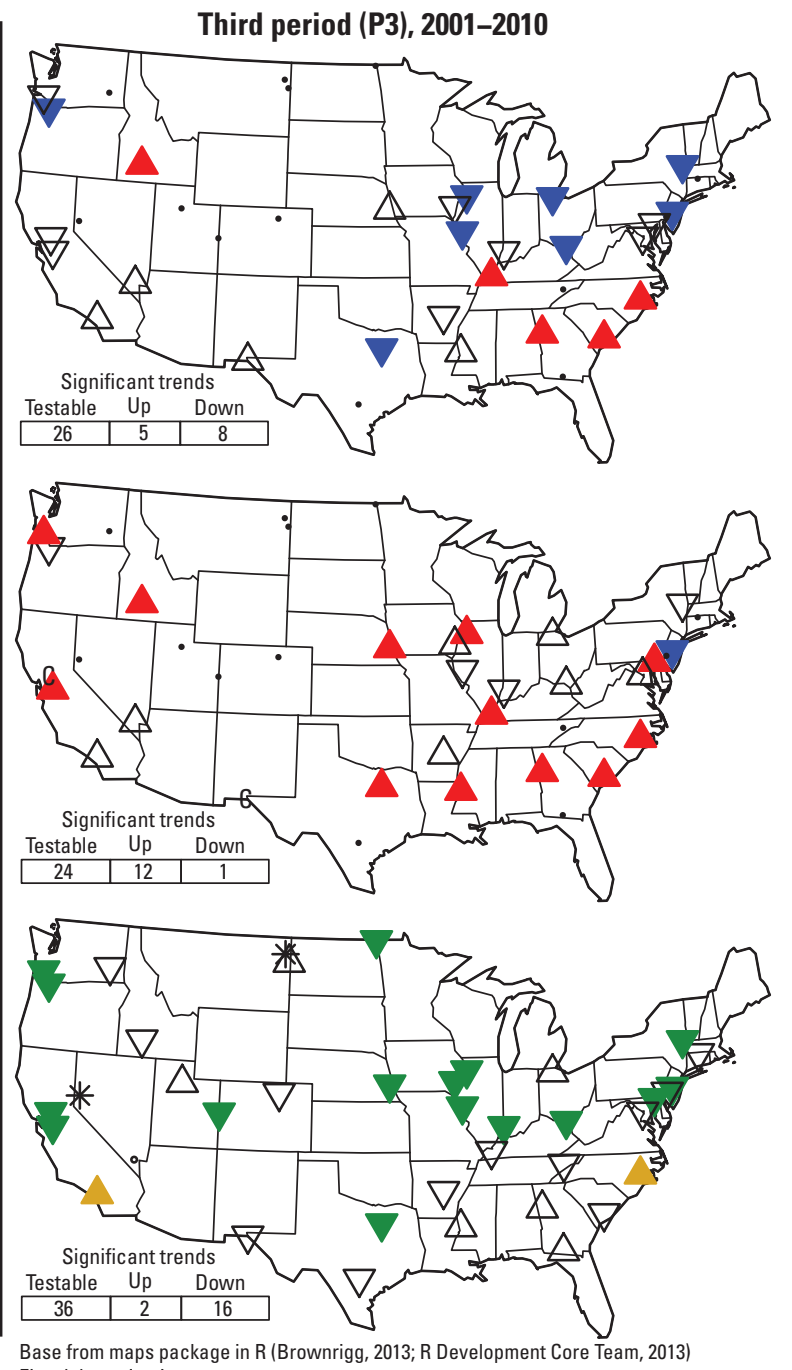

Base from maps package in $R$ (Brownrigg, 2013; $R$ Development Core Team, 2013)

棓

Figure 8. Atrazine and deethylatrazine concentration trends and atrazine agricultural-use trends at independent trend sites, $1992-2010$. 
First period (P1), 1992-2001
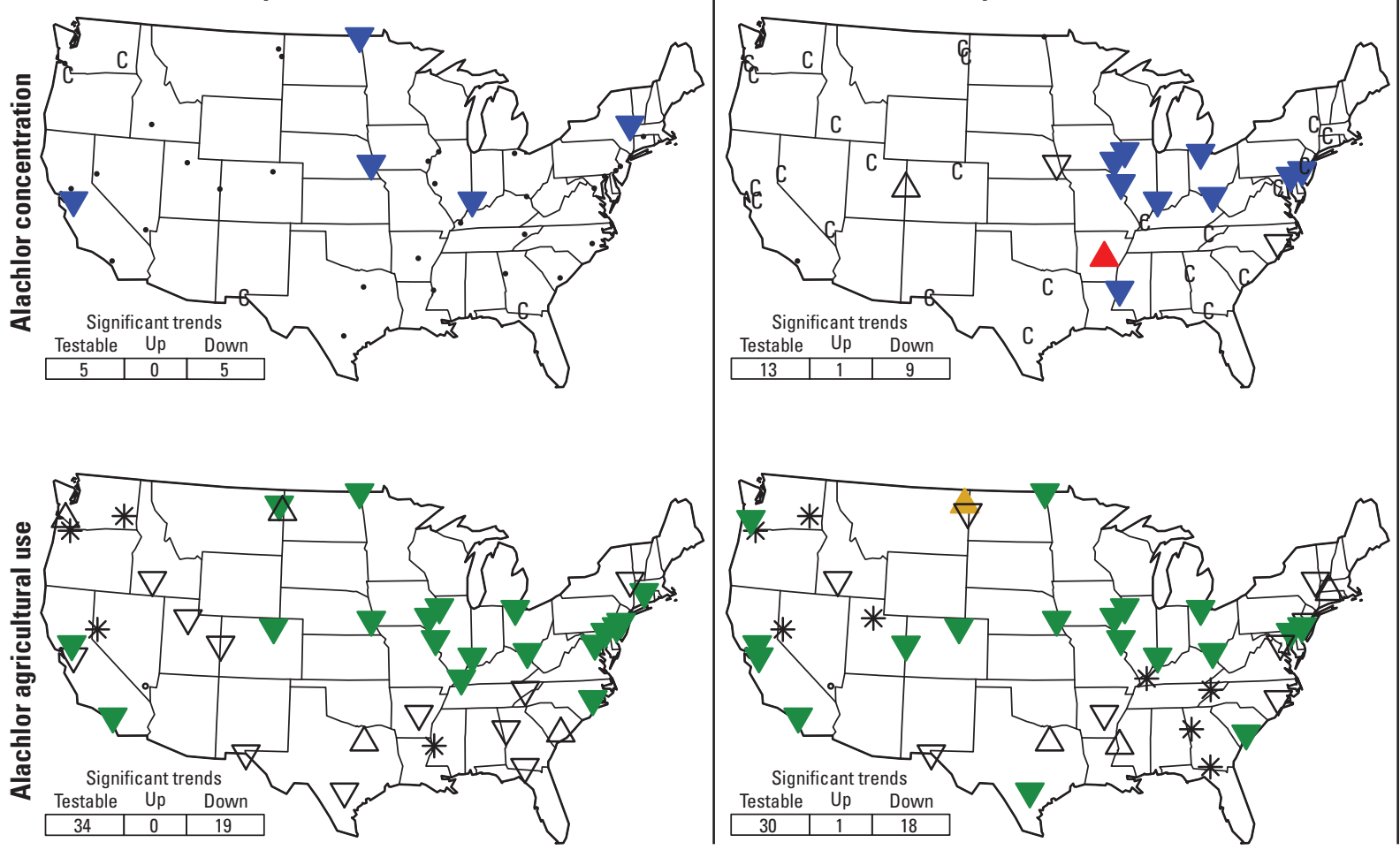

\section{EXPLANATION}

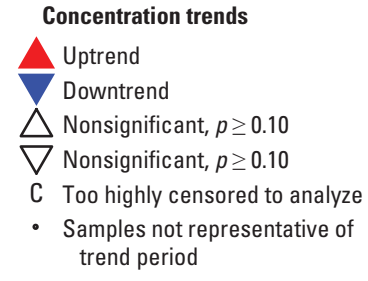

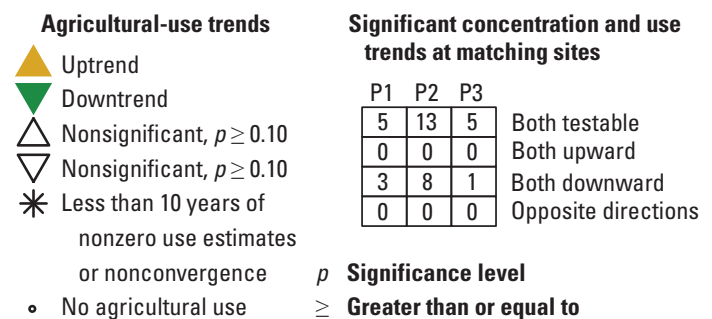

Third period (P3), 2001-2010
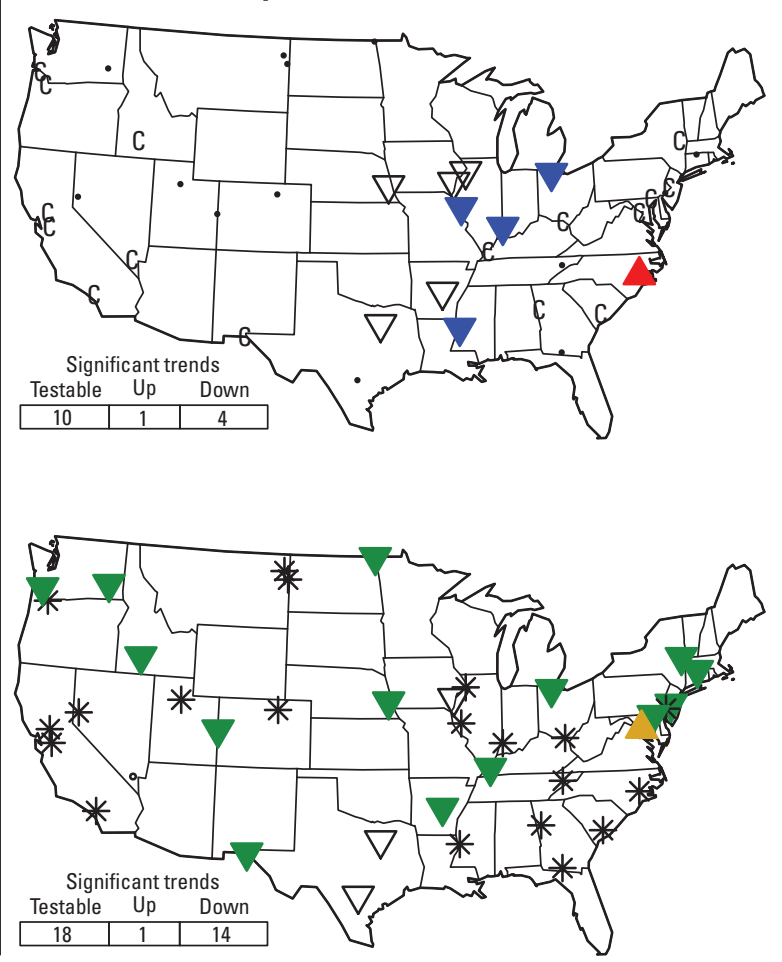

Base from maps package in R (Brownrigg, 2013; R Development Core Team, 2013) Base from maps packas
Eisenlohr projection

Figure 9. Alachlor concentration and agricultural-use trends at independent trend sites, 1992-2010. 
and others (2010) found that for 14 assessable urban streams in 1996-2004 and 11 in 2000-2008, there were 10 significant downtrends, 2 uptrends, and 13 nonsignificant trends, with one or more downtrends in all regions of the country.

Trend results for major rivers are generally consistent with the trends in urban streams. In each of the three periods, there were more significant downtrends than uptrends. During 1997-2006, when available data allowed the most comprehensive assessment, 8 of 20 assessable sites had downtrends, only 1 had an uptrend, and 11 were nonsignificant (fig. 10).

\section{Dacthal}

Dacthal is a pre-emergent herbicide used to control annual grasses and broadleaf weeds on ornamental turf and plants, strawberries, vegetables, cotton, and field beans (U.S. Environmental Protection Agency, 1998b). National agricultural use of Dacthal, mostly on vegetables and fruit, declined rapidly during 1992-2001 and then generally leveled off during 2002-10 (fig. 3). Similar to tebuthiuron, Kiely and others (2004) estimated that 1999 nonagricultural uses were substantially greater than for agriculture. Ryberg and others (2010) found that for seven assessable urban streams in 1996-2004, there were four significant downtrends and one uptrend, and for three assessable streams in 2000-2008, there were three nonsignificant trends.

Concentration trend results for major rivers are generally consistent with agricultural-use trends and the trends in urban streams. For 1992-2001, there were six sites with assessable concentration trends and all had significant downtrends, with one also having a significant downtrend in use. During 1997-2006, results were more mixed, with two significant downtrends (one with a significant use downtrend) and two significant uptrends out of eight assessable sites, with all sites located in the western United States. During 2001-10, all six assessable sites were also in the west, with three uptrends (one with a significant use uptrend) and one downtrend in concentration (fig. 11).

\section{Pendimethalin}

Pendimethalin is a selective herbicide used to control broadleaf weeds and grassy weed species in agricultural and nonagricultural areas, including residential lawns and ornamentals (U.S. Environmental Protection Agency, 1997a). National agricultural use, mostly for soybeans and corn, increased from 1992-97, decreased from 1997-2003, and then remained relatively constant through 2010 (fig. 3). Although pendimethalin had much more agricultural use than tebuthiuron and Dacthal (fig. 3), its frequency of detection in water samples is low and too highly censored to calculate concentration trends at most sites. Pendimethalin has a high $\log K_{o c}$ and thus strongly binds to particulate matter, and has high volatility (tables 3 and 4), both of which reduce its concentrations in filtered water samples. The number of assessable sites for concentration trends was low and similar to tebuthiuron and Dacthal, even though agricultural-use data were adequate to evaluate trends at most sites. Across all three periods, there were no clear patterns in concentration trends, though five siteperiod cases with significant trends for both concentration and use were in the same direction (fig. 12).

\section{Insecticides}

Graphical trends results for insecticides at independent trend sites are shown in figures 13-18. As for some herbicides, trends for particular insecticide site-period cases often could not be calculated for both concentration and agricultural use because concentration samples were not representative of a particular period, concentration was too highly censored for trend analysis, there was no reported agricultural use of pesticides, there were less than 10 years of nonzero use estimates, or the interval censored regression algorithm was unable to converge to a solution for the use trends. The lack of coincident trends limited opportunities for site-by-site comparisons of concentration and agricultural-use trends.

\section{Chlorpyrifos}

Chlorpyrifos is an insecticide and acaricide with a number of agricultural uses (cattle ear tags, foliage and soilborne insect control on food and feed crops, Christmas tree farms) and nonagricultural uses (golf courses, termites, fire ant control, adult mosquitocide, and others; U.S. Environmental Protection Agency, 2002). Chlorpyrifos trends are shown in figure 13. Few sites were assessable for concentration trends in the first period, and all three that were significant were downtrends. The uptrends in the second and third periods are unexpected given a general decline in agricultural usage (fig. 3); 1997-2005 phase outs of residential and termite uses; and reductions in applications rates for outdoor areas including road medians, industrial sites, and golf-course turf (U.S. Environmental Protection Agency, 2002). Ryberg and others (2010) found significant downtrends in chlorpyrifos concentration for 9 out of 10 urban sites that could be analyzed for a period similar to the second trend period (1996-2004), which supports the hypothesis that phase outs of residential uses should cause downward concentration trends. Thus, agricultural usage is a more likely explanation for the uptrends. However, of the six significant concentration uptrends, only one (SACRA, period 2; table 6) had a significant use uptrend and two (WILMT, period 2; MAUM, period 3) had significant use downtrends (fig. 13).

\section{Malathion}

Malathion is a broad-spectrum insecticide and acaricide with numerous agricultural, commercial industrial, governmental (for example, mosquito eradication programs), and homeowner uses (U.S. Environmental Protection Agency, 
First period (P1), 1992-2001
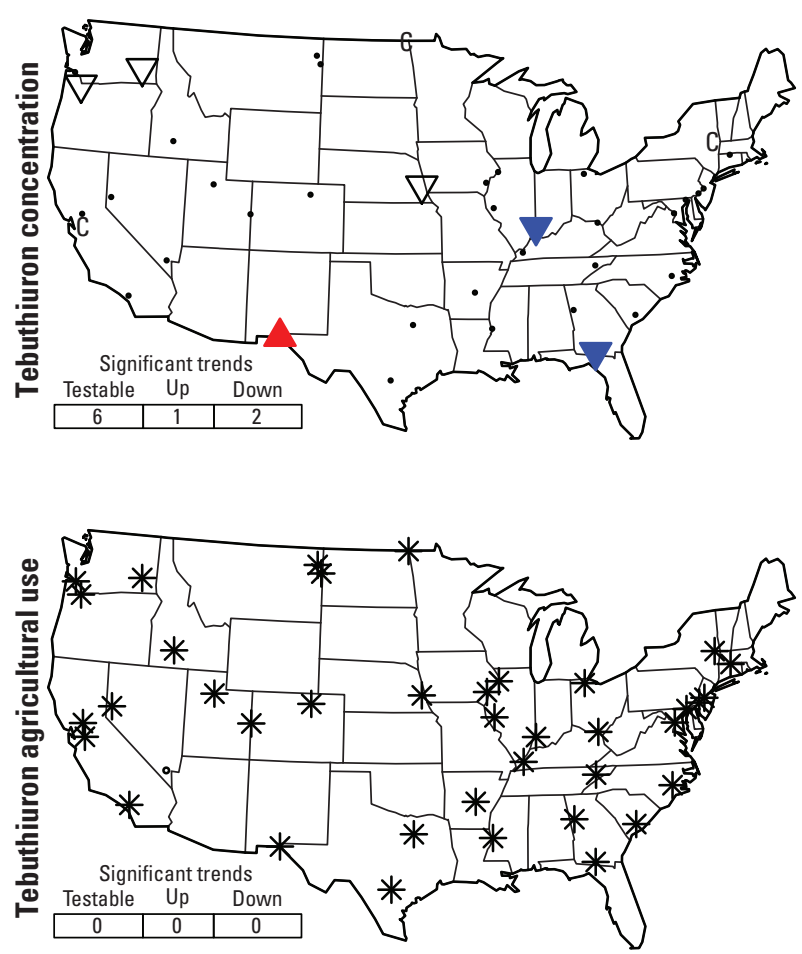

Concentration trends

$\triangle$ Uptrend

$\nabla$ Downtrend

$\triangle$ Nonsignificant, $p \geq 0.10$

$\nabla$ Nonsignificant, $p \geq 0.10$

C Too highly censored to analyze

- Samples not representative of trend period
Second period (P2), 1997-2006
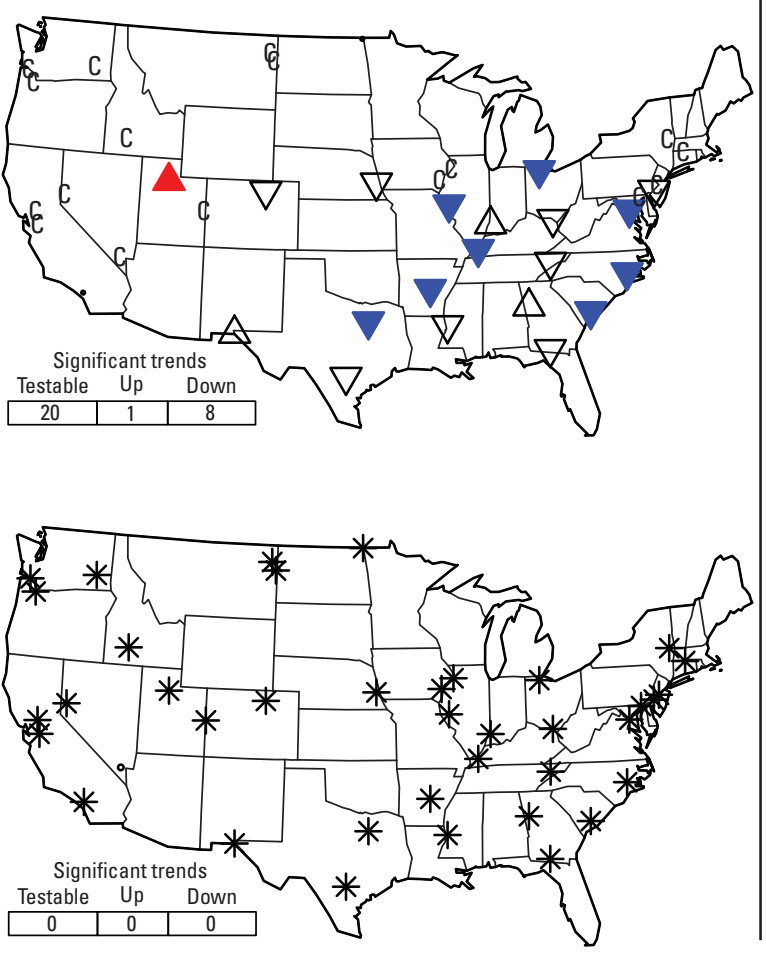

\section{EXPLANATION}

\begin{tabular}{|c|c|c|c|}
\hline \multirow{2}{*}{$\begin{array}{l}\text { Agricultural-use trends } \\
\text { Uptrend } \\
\text { Downtrend }\end{array}$} & \multicolumn{3}{|c|}{$\begin{array}{l}\text { Significant concentration and use } \\
\text { trends at matching sites }\end{array}$} \\
\hline & P1 P2 & & \\
\hline$\triangle$ Nonsignificant, $p \geq 0.10$ & \begin{tabular}{|l|l|}
0 & 0 \\
\end{tabular} & 0 & Both testable \\
\hline$\nabla$ Nonsignificant, $p \geq 0.10$ & 0 & 0 & Both upward \\
\hline * Less than 10 years of & 0 & 0 & Both downward \\
\hline nonzero use estimates & 0 & 0 & Opposite directions \\
\hline
\end{tabular}

Figure 10. Tebuthiuron concentration and agricultural-use trends at independent trend sites, 1992-2010.
Third period (P3), 2001-2010
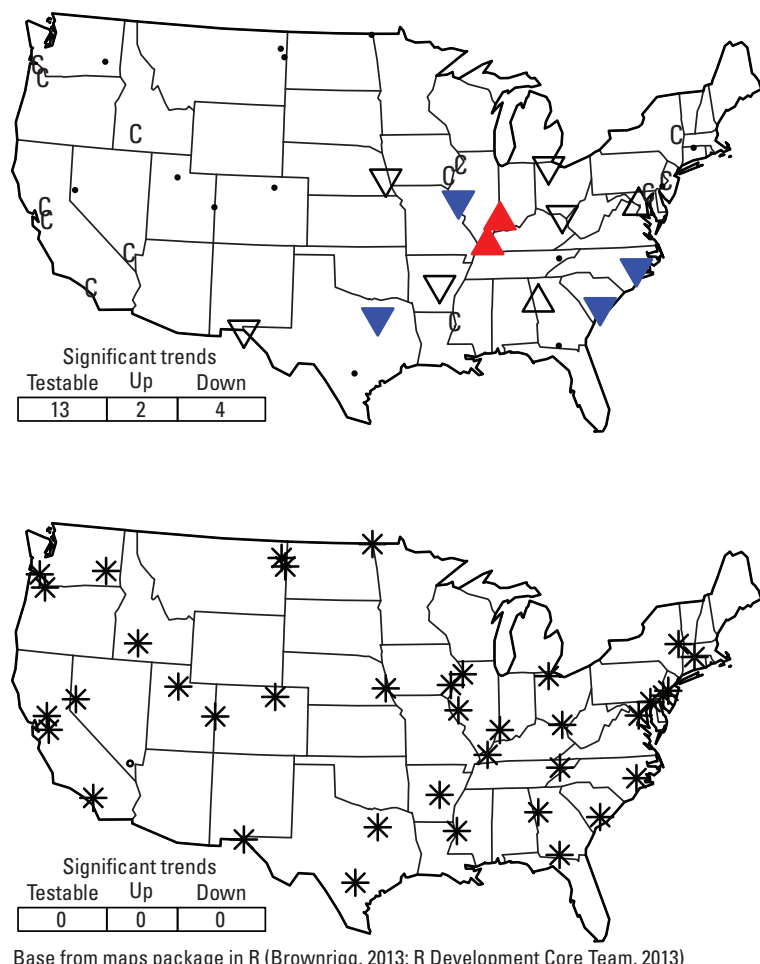

Base from maps package in $\mathrm{R}$ (Brownrigg, 2013; $\mathrm{R}$ Development Core Team, 2013) Eisenlohr projection 

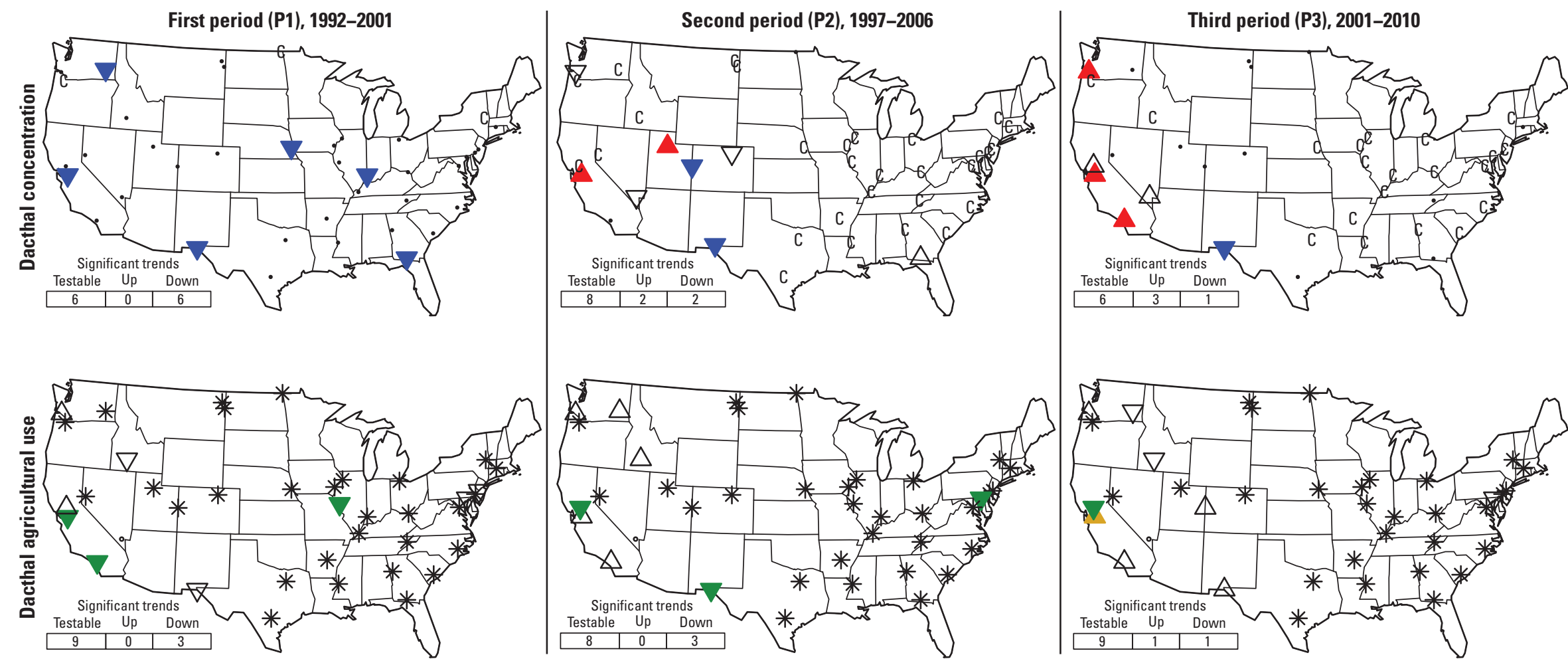

\section{EXPLANATION}

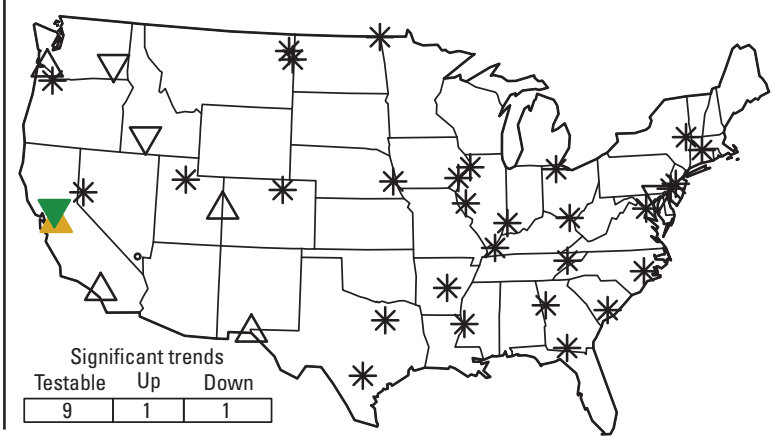

Base from maps package in R (Brownrigg, 2013; R Development Core Team, 2013) Eisenlohr projection

Concentration trends
Uptrend
Downtrend
$\triangle$ Nonsignificant, $p \geq 0.10$
$\nabla$ Nonsignificant, $p \geq 0.10$
$C$ Too highly censored to analyze
- Samples not representative of
trend period

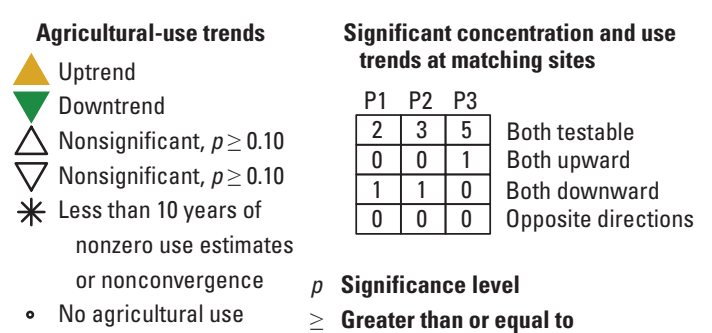

Figure 11. Dacthal concentration and agricultural-use trends at independent trend sites, 1992-2010. 
First period (P1), 1992-2001
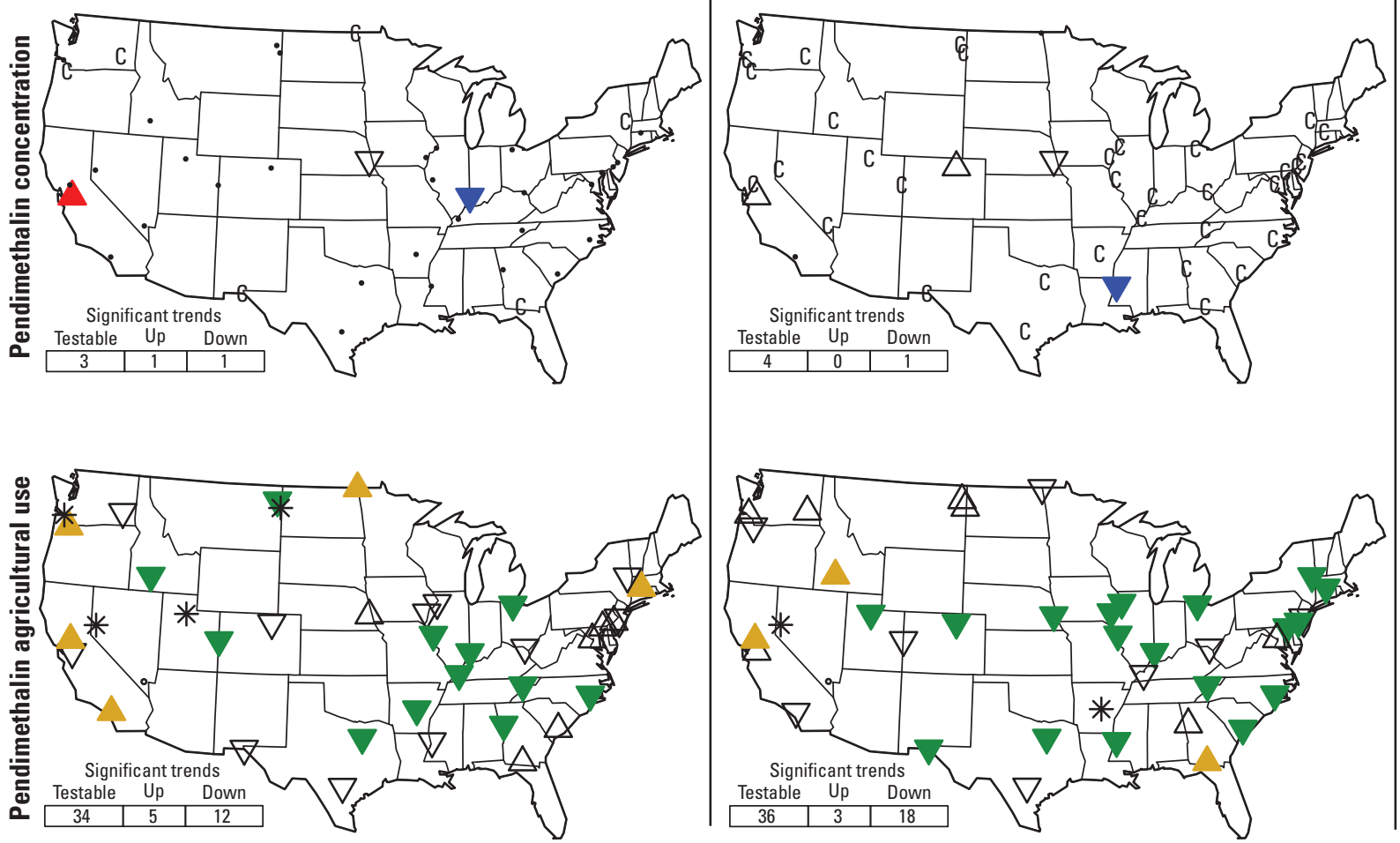

EXPLANATION
Third period (P3), 2001-2010
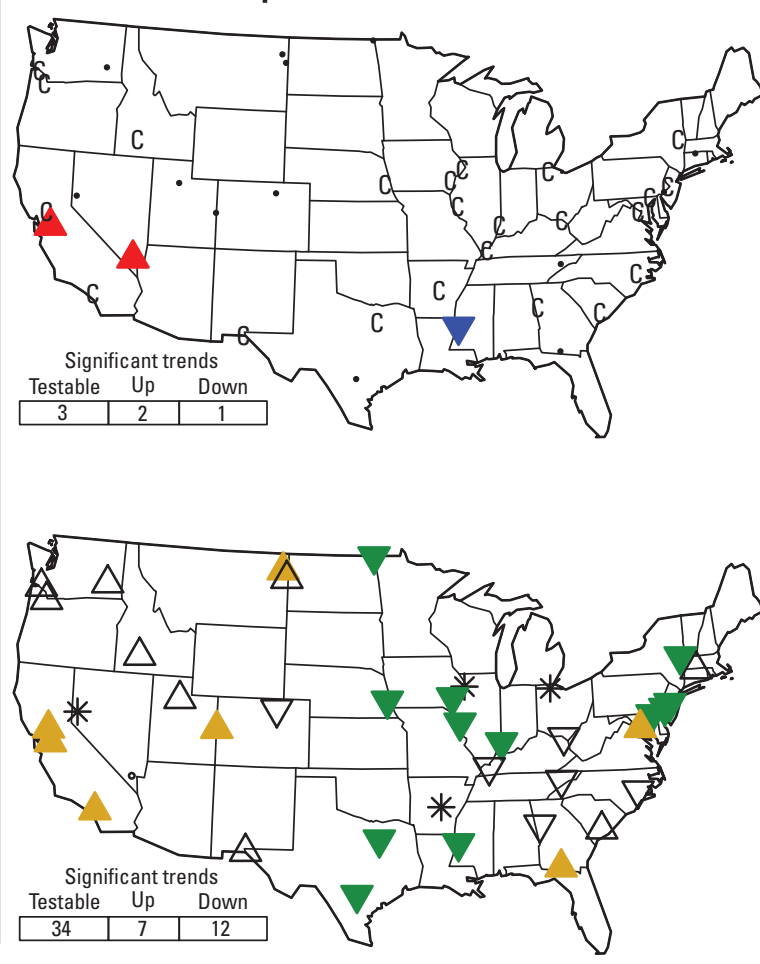

Base from maps package in $\mathrm{R}$ (Brownrigg, 2013; $\mathrm{R}$ Development Core Team, 2013) Eisenlohr projection
Concentration trends

$\triangle$ Uptrend

$\nabla$ Downtrend

$\triangle$ Nonsignificant, $p \geq 0.10$

$\nabla$ Nonsignificant, $p \geq 0.10$

C Too highly censored to analyze

- Samples not representative of trend period

\begin{tabular}{|c|c|c|c|c|}
\hline $\begin{array}{l}\text { Agricultural-use trends } \\
\text { Uptrend }\end{array}$ & \multicolumn{4}{|c|}{$\begin{array}{l}\text { Significant concentration and use } \\
\text { trends at matching sites }\end{array}$} \\
\hline$\nabla$ Downtrend & \multicolumn{4}{|c|}{$\begin{array}{lll}P 1 & P 2 & P 3 \\
\end{array}$} \\
\hline$\triangle$ Nonsignificant, $p \geq 0.10$ & \begin{tabular}{|l|}
3 \\
\end{tabular} & 4 & 2 & Both testable \\
\hline$\nabla$ Nonsignificant, $p \geq 0.10$ & 0 & 0 & 1 & Both upward \\
\hline $\begin{array}{l}\text { * Less than } 10 \text { years of } \\
\text { nonzero use estimates }\end{array}$ & $\frac{1}{0}$ & $\frac{1}{0}$ & $\frac{1}{0}$ & $\begin{array}{l}\text { Both downward } \\
\text { Opposite directions }\end{array}$ \\
\hline $\begin{array}{l}\text { nonzero use estimates } \\
\text { or nonconvergence } \\
\text { - No agricultural use }\end{array}$ & Great & & & equal to \\
\hline
\end{tabular}

Figure 12. Pendimethalin concentration and agricultural-use trends at independent trend sites, 1992-2010. 

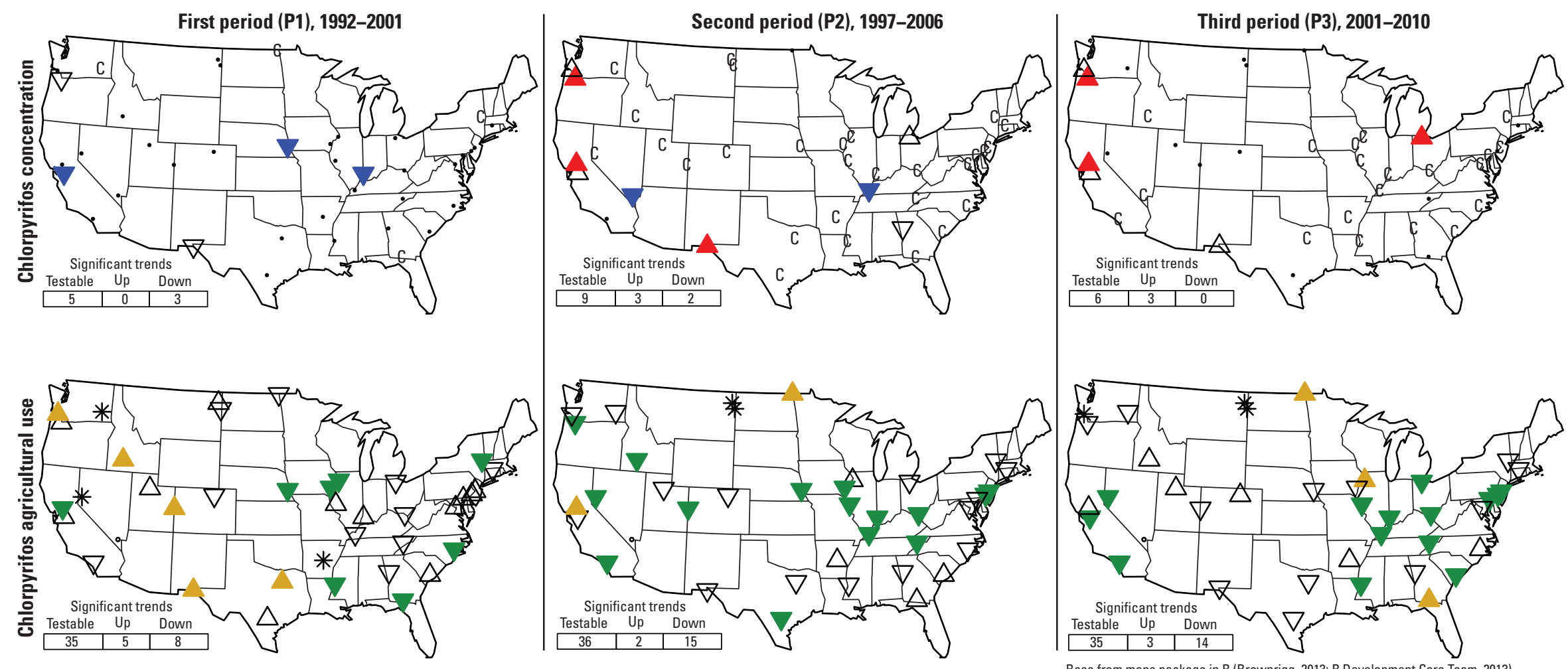

EXPLANATION

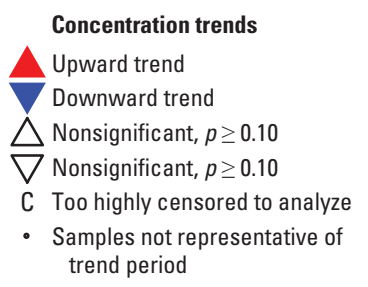

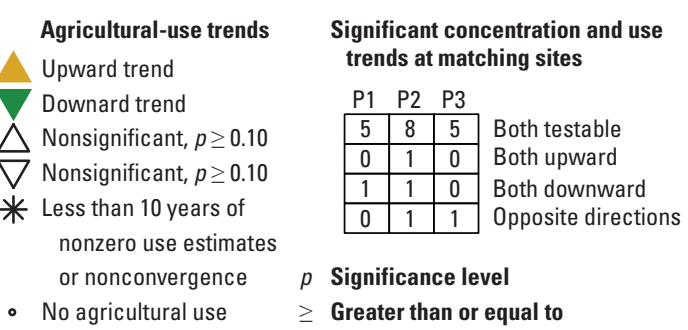

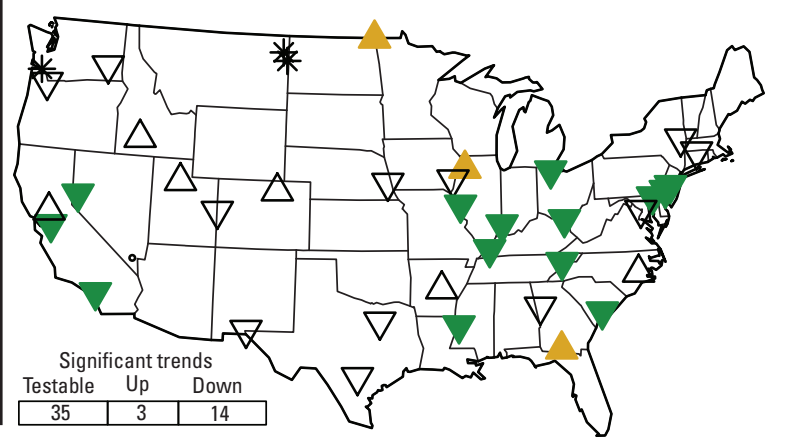

Base from maps package in $R$ (Brownrigg, 2013; $R$ Development Core Team, 2013) Eisenlohr projection 
2009). All statistically significant concentration trends for malathion were downtrends (fig. 14) but few sites had sufficient data for concentration analysis in any of the three periods, which matches with a general decline in agricultural use (fig. 3). In addition, malathion is non-persistent in soil and water (tables 3 and 4 ) and thus very little of the amount applied reaches rivers. In the few cases where statistically significant concentration and agricultural-use trends could be compared, both were down.

\section{Diazinon}

Diazinon is one of the most widely used insecticides in the United States and is also used as an acaricide and nematicide (U.S. Environmental Protection Agency, 2006e). All indoor and outdoor residential uses of diazinon have been cancelled and sales were phased out, ending December 31, 2004 (U.S. Environmental Protection Agency, 2006e, 2008c). Concentration and agricultural-use trends were almost all downward (fig. 15). The one statistically significant uptrend in concentration occurred at JORDN (tables 1 and 6). This uptrend likely had to do with the agricultural uses of diazinon, which include control of insects on fruit, nut, vegetable, and ornamental crops (U.S. Environmental Protection Agency, 2006e). This trend occurred in the second period, 1997-2006, and there were uptrends in agricultural use in this basin for this and the prior period, although neither trend was statistically significant (table 6 and fig. 15).

\section{Fipronil and Desulfinylfipronil}

Fipronil is a broad-spectrum insecticide that is relatively new compared to other insecticides in this study (table 2; U.S. Environmental Protection Agency, 1996a). Fipronil is a replacement candidate for insecticides that have been phased out, such as chlorpyrifos and diazinon (Phillips and others, 2007). Agricultural usages showed an increase then a decline in 2006 (fig. 3). All statistically significant concentration trends for fipronil and desulfinylfipronil were upward (fig. 16). Conversely, the few agricultural-use trends that were assessable were all statistically significant and downward. In a previous trend analysis of pesticide concentrations in 27 urban streams (Ryberg and others, 2010), all assessable fipronil trends, except one, and all desulfinylfipronil trends were significant and upward. The decreases in agricultural use, in the limited results shown here, and the increases in concentrations in major rivers and urban streams indicate the likelihood that increases in concentration are coming from nonagricultural uses.

\section{Carbofuran}

Carbofuran is a broad-spectrum insecticide and nematicide that is used for the control of soil and foliar pests in a variety of food and feed crops (U.S. Environmental Protection Agency, 2007). Concentrations of carbofuran are generally too highly censored for trend analysis and most agricultural-use trends are down in the first and second periods, with most of the basins in third period having too many zeroes in usage estimates to be able to calculate trends (fig. 17). Restrictions on the use of carbofuran explain this decline in use and the decline that can be seen in the total usage (fig. 3). Carbofuran is classified as a restricted use pesticide and the sale of granular carbofuran is limited to $1,134 \mathrm{~kg}$ of active ingredient per year for use only on certain crops, while the estimated annual average usage of the active ingredient in liquid formulation is $453,592 \mathrm{~kg}$ (estimated in 2006 ; U.S. Environmental Protection Agency, 2007). The technical registrant made a number of label changes in the late 1990s to reduce drinking water and ecological risks. These changes included reducing application rates and the reducing the number of applications for some soils (to reduce potential groundwater contamination) and for alfalfa, cotton, corn, potatoes, soybeans, sugarcane, and sunflowers. In 2006, the use of granular carbofuran was limited to spinach grown for seed, pine seedlings, bananas (in Hawaii only), and cucurbits (U.S. Environmental Protection Agency, 2007).

The only statistically significant trend in concentration was upward and occurred at COLO-SL (table 6). During the same period, there also was a statistically significant uptrend in agricultural use at this site and that trend was the only statistically significant uptrend in agricultural use (table 6).

\section{Carbaryl}

Carbaryl is an insecticide used on a wide variety of food and feed crops, urban sites (such as golf courses), and residential sites (such as flowers and shrubs; U.S. Environmental Protection Agency, 2008a). Agricultural use was abruptly lower in 1998 and has generally continued to decline (fig. 3). Carbaryl trends are generally downward for both concentration and agricultural use (fig. 18). There were two uptrends in concentration and both occurred in the second period, 1997-2006. In its Interim Reregistration Eligibility Document (IRED; U.S. Environmental Protection Agency, 2004), the EPA indicated a decline in agricultural usage of carbaryl and this can be seen in the agricultural-use trends. All of the statistically significant agricultural-use trends are downward, except for one uptrend in the first period at MIZZ-CB (table 6). One of the uptrends in concentration in this major river study, MOHWK (table 6), had a comparable statistically significant agricultural-use trend and that trend was down (table 6). 


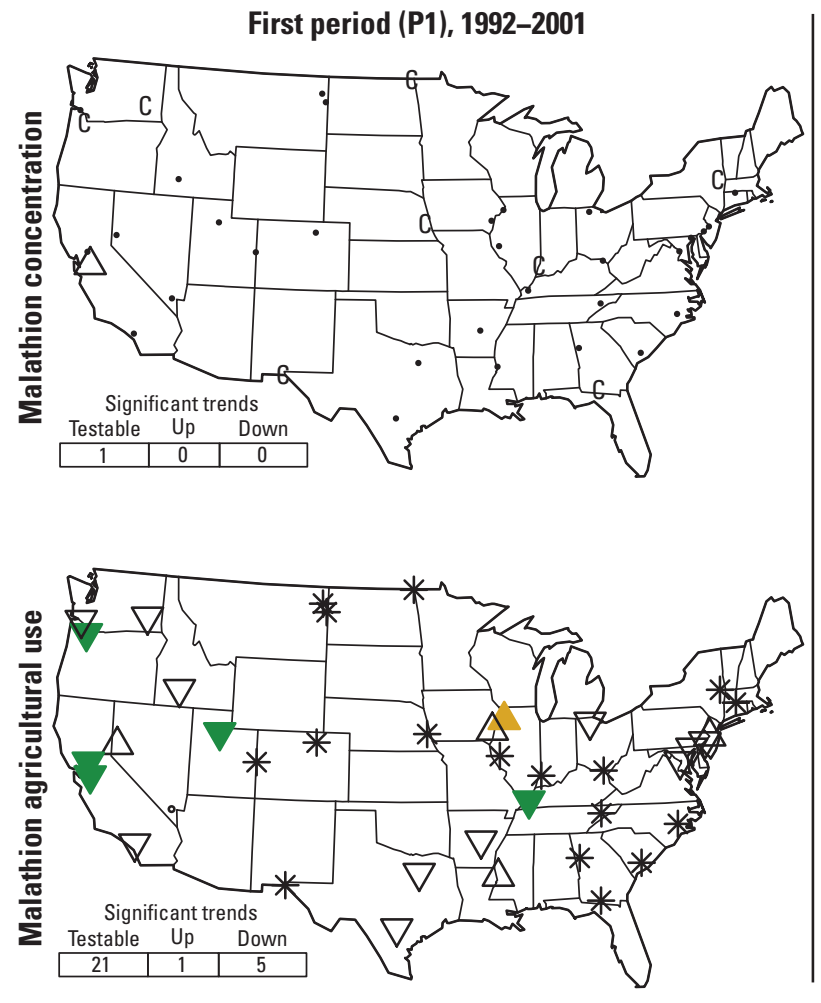

Concentration trends

$\triangle$ Uptrend

$\nabla$ Downtrend

$\triangle$ Nonsignificant, $p \geq 0.10$

$\nabla$ Nonsignificant, $p \geq 0.10$

C Too highly censored to analyze

- Samples not representative of trend period
Second period (P2), 1997-2006
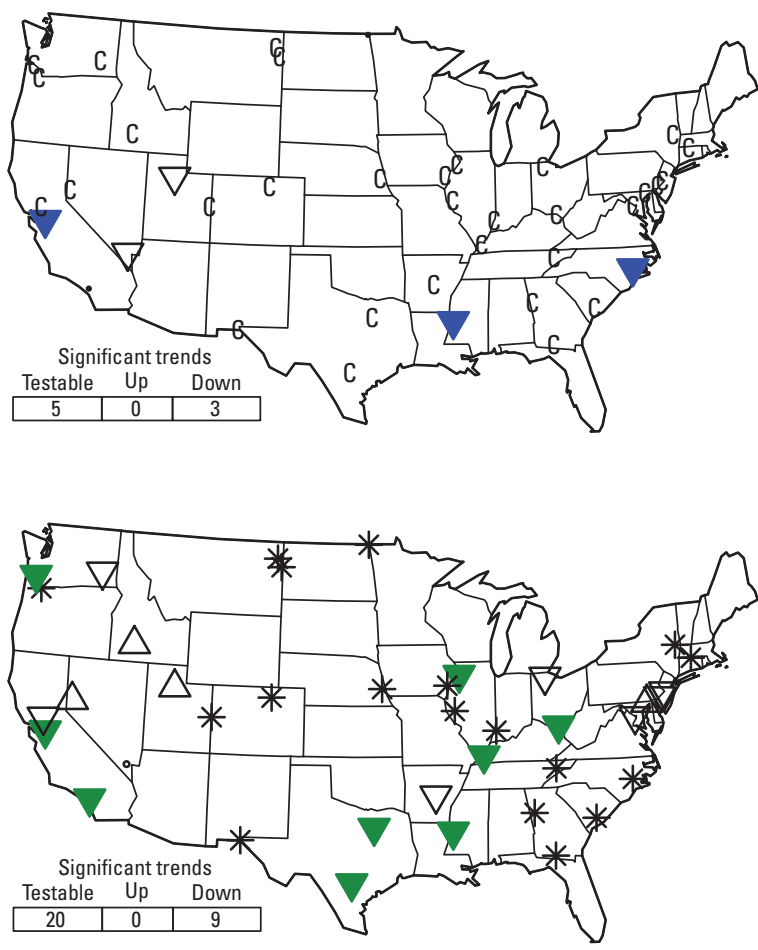

EXPLANATION
Third period (P3), 2001-2010
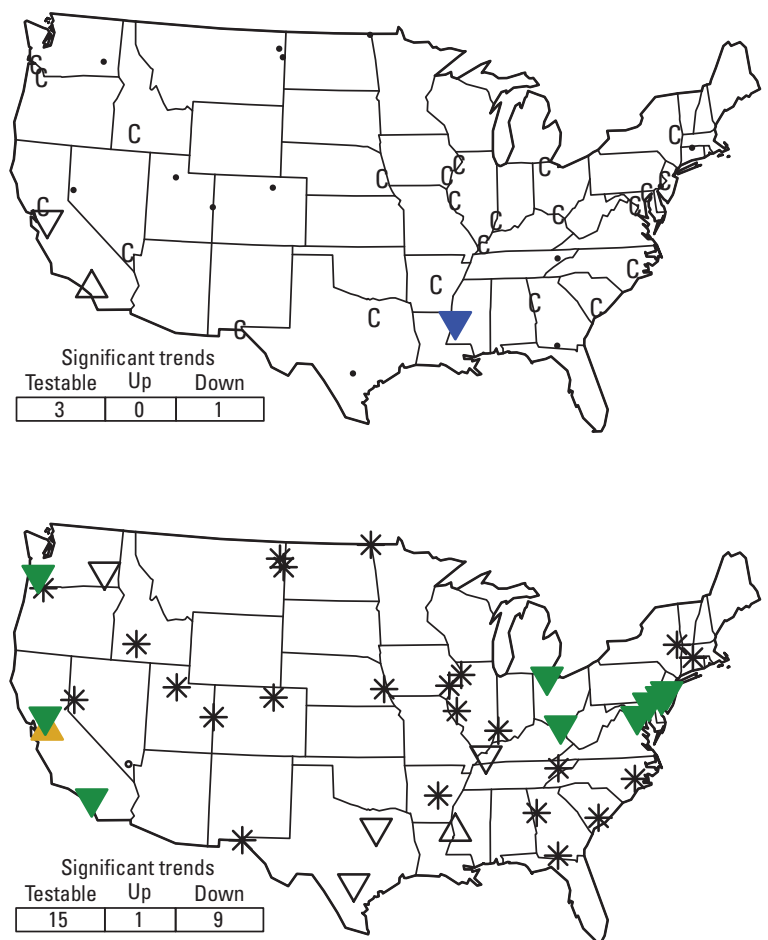

Base from maps package in $\mathrm{R}$ (Brownrigg, 2013; $\mathrm{R}$ Development Core Team, 2013) Eisenlohr projection

Figure 14. Malathion concentration and agricultural-use trends at independent trend sites, 1992-2010.

Significant concentration and use

ends at matching sites

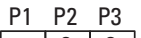

$\begin{array}{lllll}1 & 0 & 0 & 30 \text { B upward }\end{array}$

$\begin{array}{lllll}0 & 2 & 0 & \text { Both downward }\end{array}$

\begin{tabular}{|l|l|l|l}
\hline 0 & 0 & 0 & Opposite directions \\
\hline
\end{tabular}

$p$ Significance level

$\geq$ Greater than or equal to 


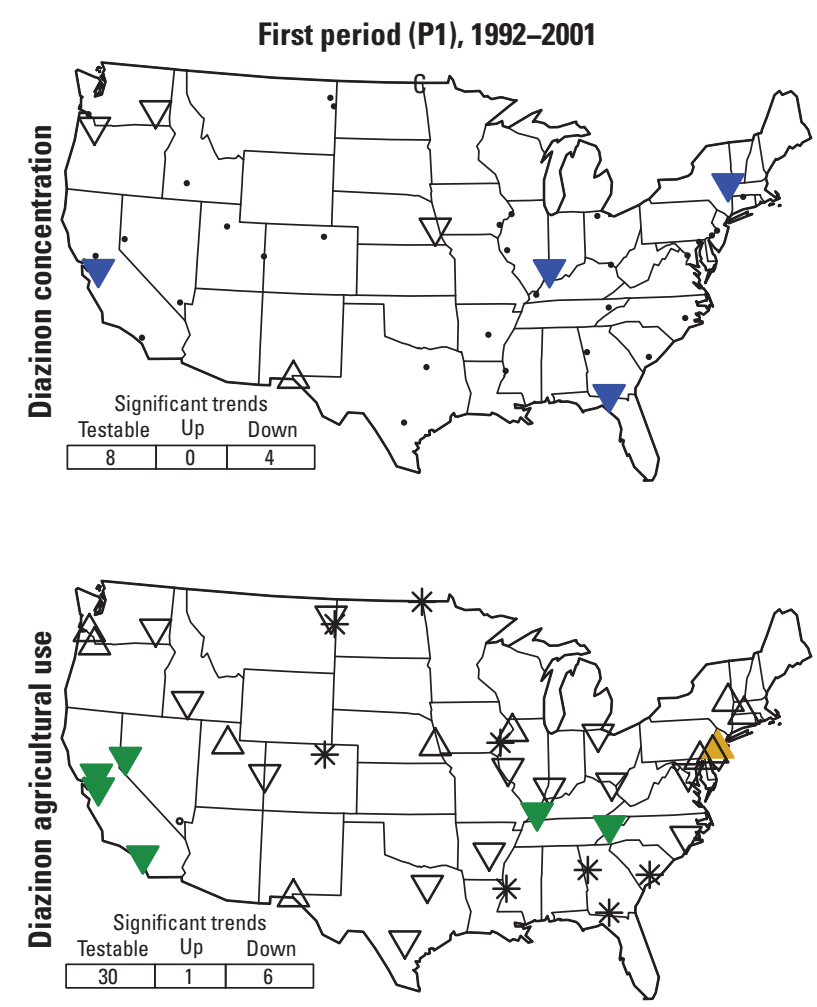$$
\text { Testa }
$$

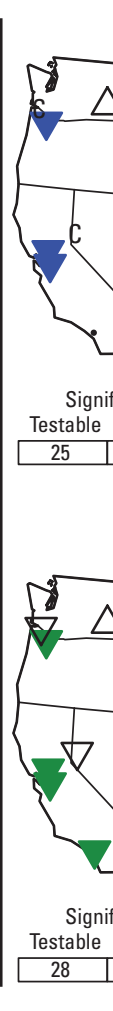

Second period (P2), 1997-2006
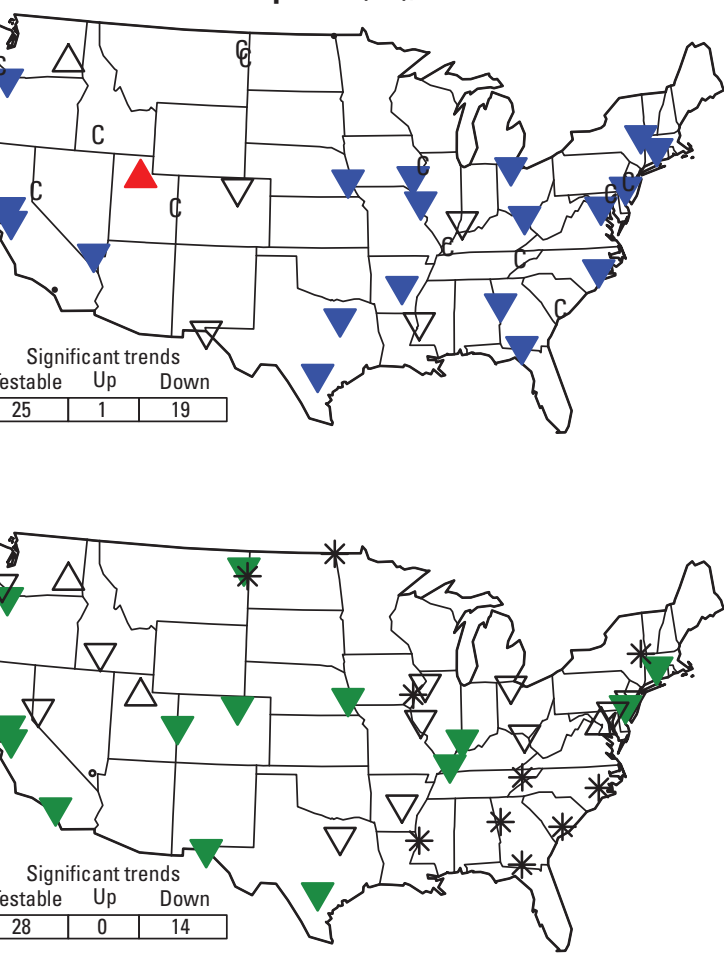

EXPLANATION

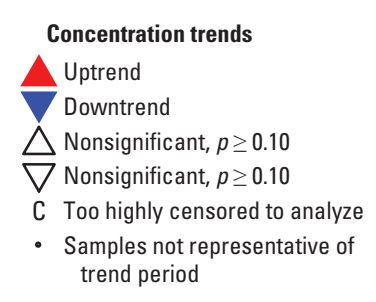

\begin{tabular}{|c|c|c|c|c|}
\hline $\begin{array}{l}\text { Agricultural-use trends } \\
\text { Uptrend }\end{array}$ & \multicolumn{4}{|c|}{$\begin{array}{l}\text { Significant concentration and use } \\
\text { trends at matching sites }\end{array}$} \\
\hline$\nabla$ Downtrend & P1 & P2 & P3 & \\
\hline$\triangle$ Nonsignificant, $p \geq 0.10$ & \begin{tabular}{|l|}
7 \\
\end{tabular} & 18 & 9 & Both testable \\
\hline$\nabla_{\text {Nonsignificant, } p \geq 0.10}$ & $\frac{0}{1}$ & $\frac{0}{7}$ & 0 & Both upward \\
\hline $\begin{array}{c}\text { * Less than } 10 \text { years of } \\
\text { nonzero use estimates }\end{array}$ & $\frac{1}{0}$ & $\frac{1}{0}$ & $\frac{1}{0}$ & $\begin{array}{l}\text { Both downward } \\
\text { Opposite directions }\end{array}$ \\
\hline $\begin{array}{l}\text { or nonconvergence } \\
\text { No agricultural use }\end{array}$ & $\begin{array}{l}\text { Signi } \\
\text { Great }\end{array}$ & & & $\begin{array}{l}\text { vel } \\
\text { equal to }\end{array}$ \\
\hline
\end{tabular}

Figure 15. Diazinon concentration and agricultural-use trends at independent trend sites, 1992-2010. Eisenlohr projection
(0)
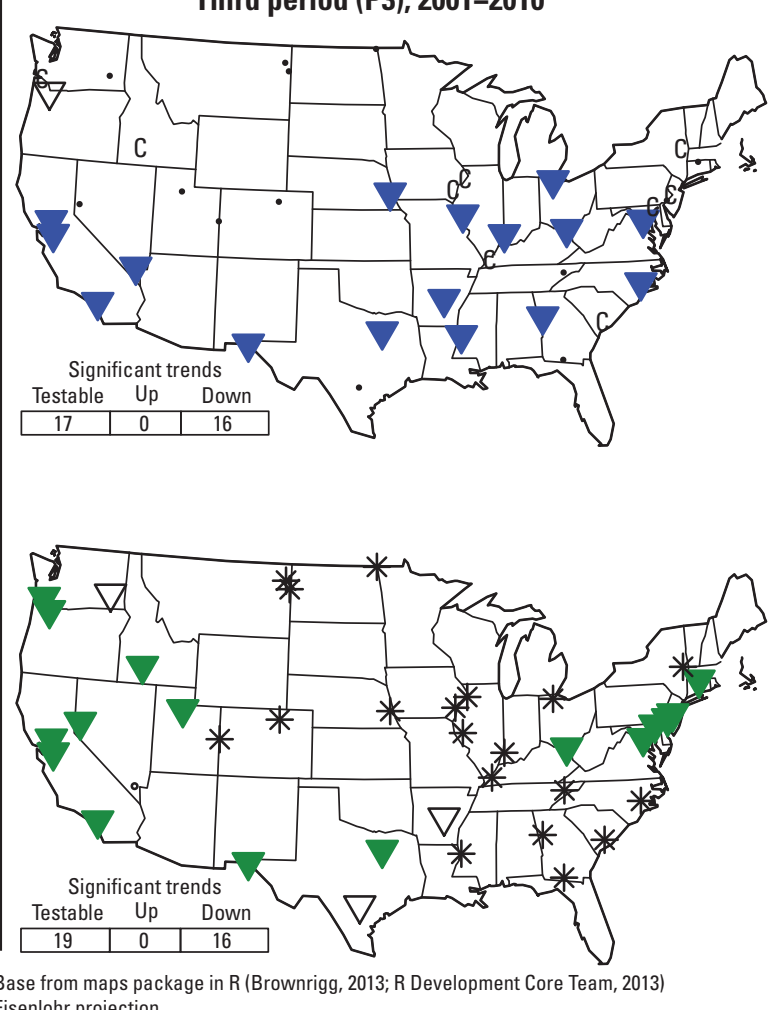
Third period (P3), 2001-2010
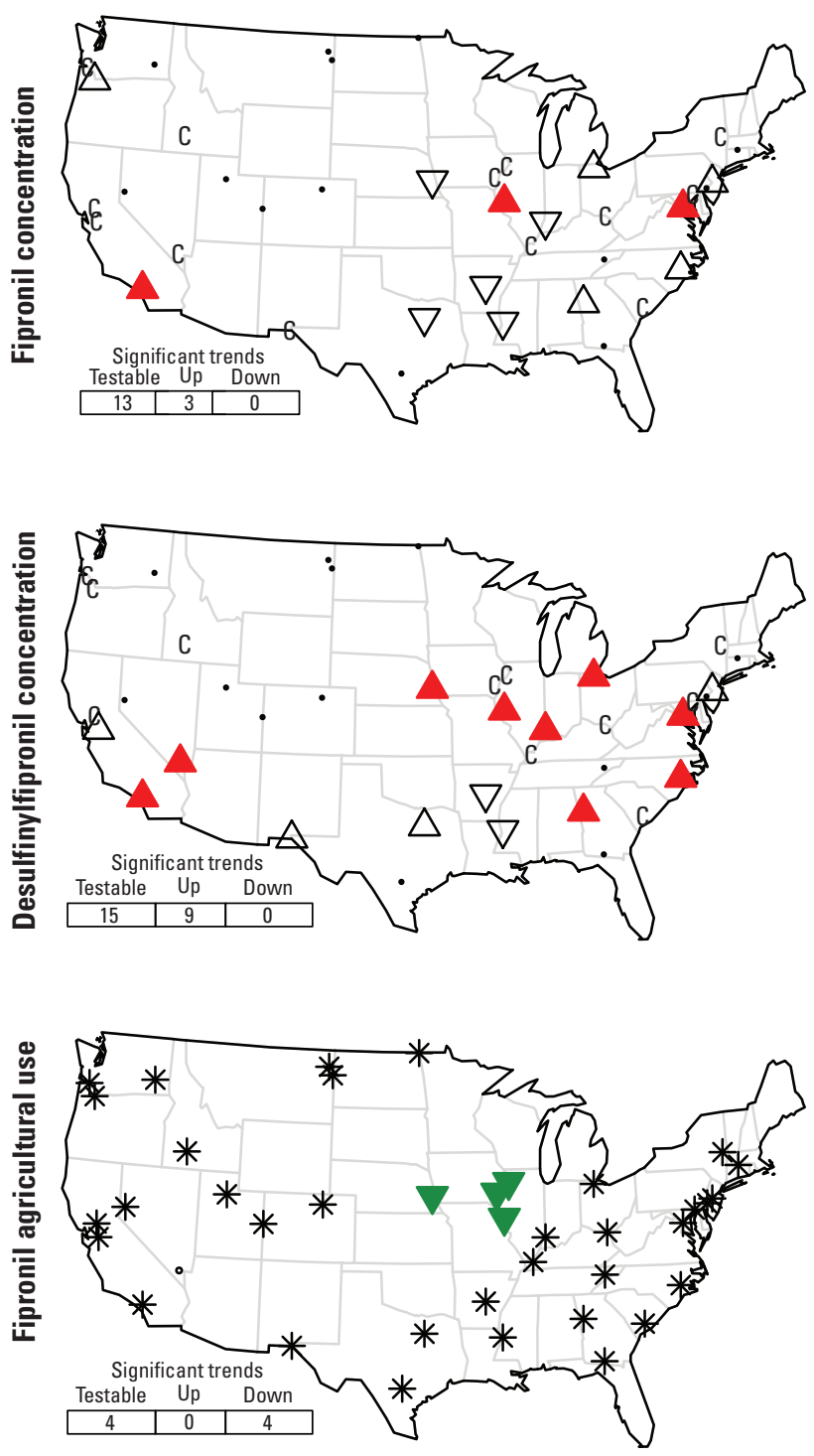

Base from maps package in $R$ (Brownrigg, 2013; R Development Core Team, 2013) Eisenlohr projection

\section{EXPLANATION}

Concentration trends

$\triangle$ Uptrend

Downtrend

$\triangle$ Nonsignificant, $p \geq 0.10$

$\nabla$ Nonsignificant, $p \geq 0.10$

C Too highly censored to analyze

- Samples not representative of trend period

Agricultural-use trends

$\triangle$ Uptrend

$\nabla$ Downtrend

$\triangle$ Nonsignificant, $p \geq 0.10$

$\nabla$ Nonsignificant, $p \geq 0.10$

* Less than 10 years of nonzero use estimates or nonconvergence

- No agricultural use

Significant concentration and use

trends at matching sites

Fipronil Desulfinylfipronil

\begin{tabular}{|l|l|l|}
\hline 2 & 2 \\
\hline 0 & 0 \\
\hline 0 & 0 \\
\hline 1 & 2 & Both testable \\
Both upward \\
Both downward \\
\hline
\end{tabular}

p Significance level

$\geq$ Greater than or equal to

Figure 16. Fipronil and desulfinylfipronil concentration and fipronil agricultural-use trends at independent trend sites, 1992-2010. 
First period (P1), 1992-2001
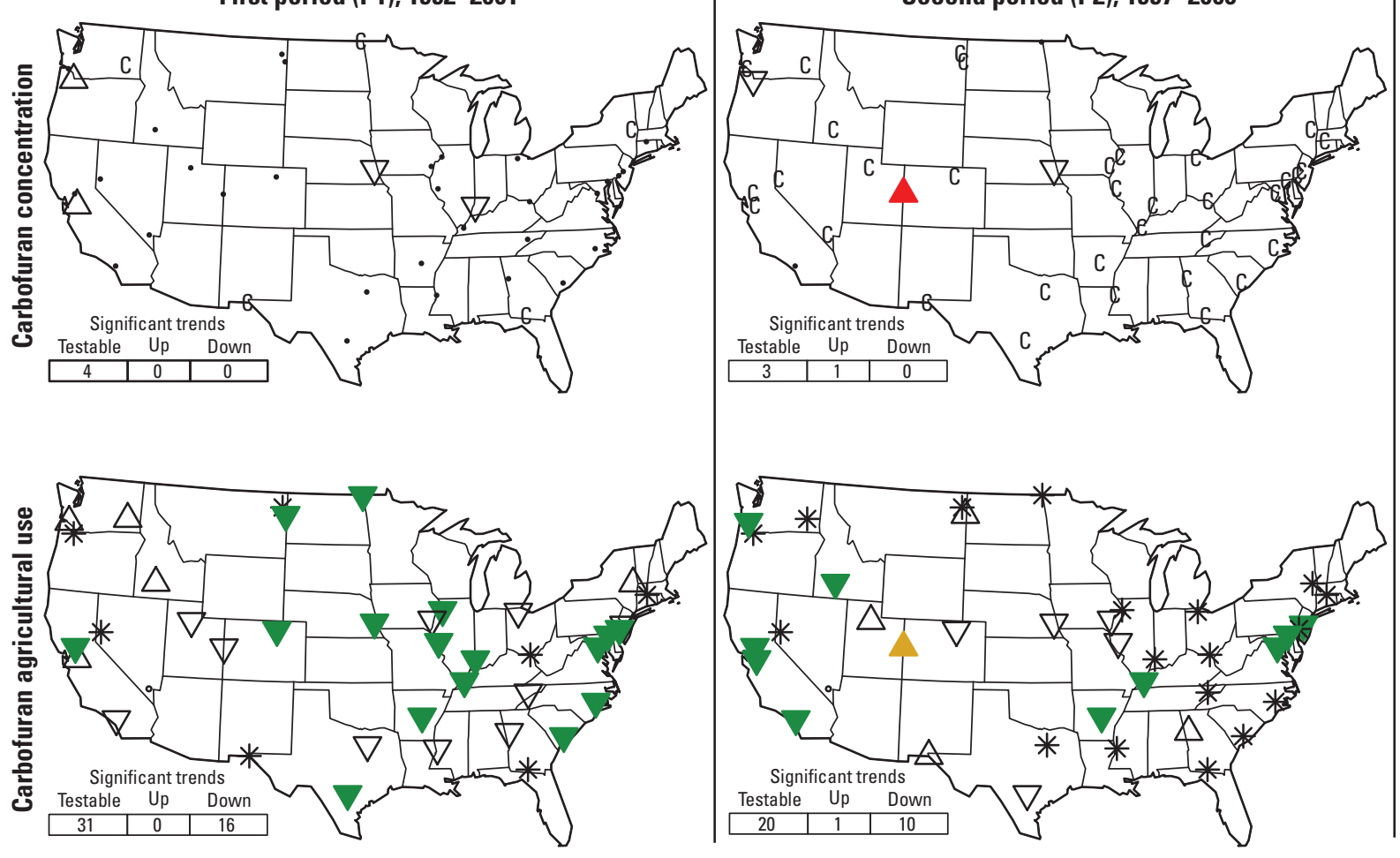

Concentration trends

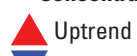

$\checkmark$ Downtrend

$\triangle$ Nonsignificant, $p \geq 0.10$

$\nabla$ Nonsignificant, $p \geq 0.10$

C Too highly censored to analyze

- Samples not representative of trend period
EXPLANATION

Second period (P2), 1997-2006

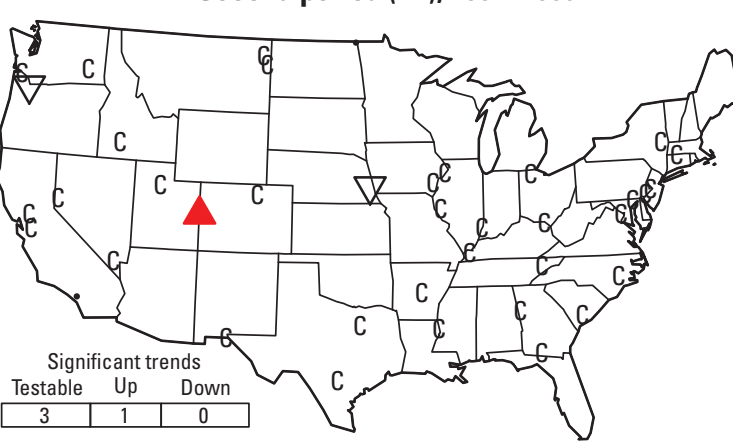

ricultural-use trends

$\triangle$ Uptrend

Downtrend

$\triangle$ Nonsignificant, $p \geq 0.10$

$\nabla$ Nonsignificant, $p \geq 0.10$

* Less than 10 years of

nonzero use estimates

or nonconvergence

- No agricultural use

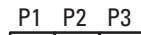

Significance leve

$\geq$ Greater than or equal to trends at matching sites

\begin{tabular}{l|l|l|l|l|l}
\hline & 2 & 0 & Both testable \\
\hline & 1 & 0 & \\
\hline
\end{tabular}

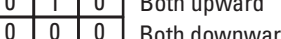

Third period (P3), 2001-2010
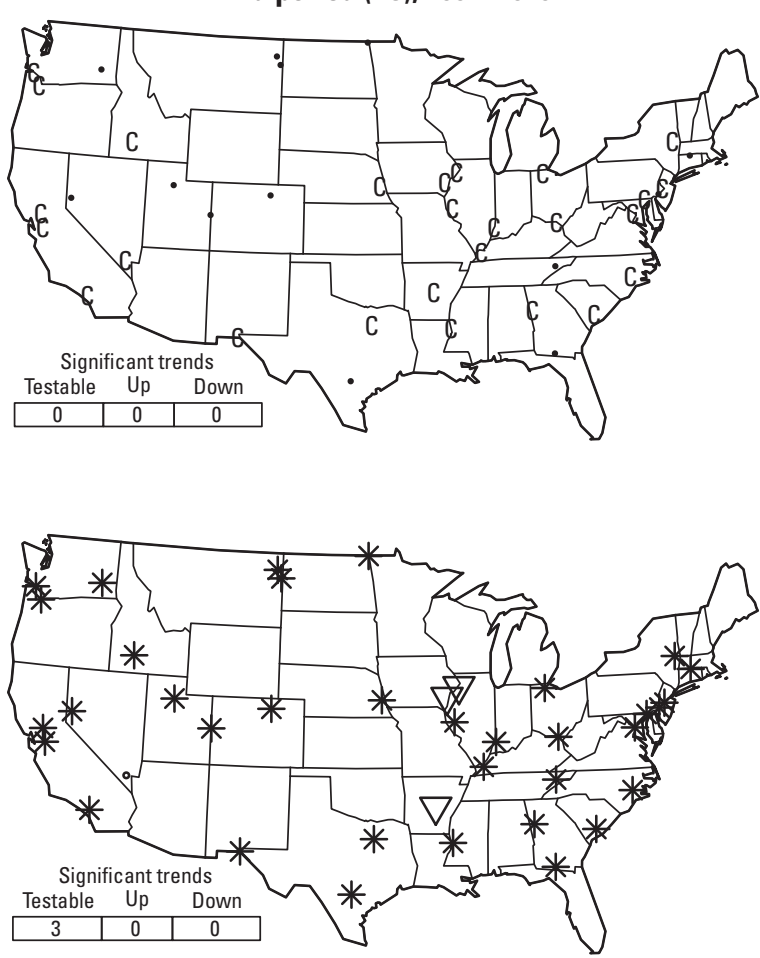

Base from maps package in R (Brownrigg, 2013; $R$ Development Core Team, 2013) Eisenlohr projectio

Significant concentration and use

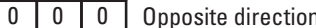

Figure 17. Carbofuran concentration and agricultural-use trends at independent trend sites, 1992-2010. 

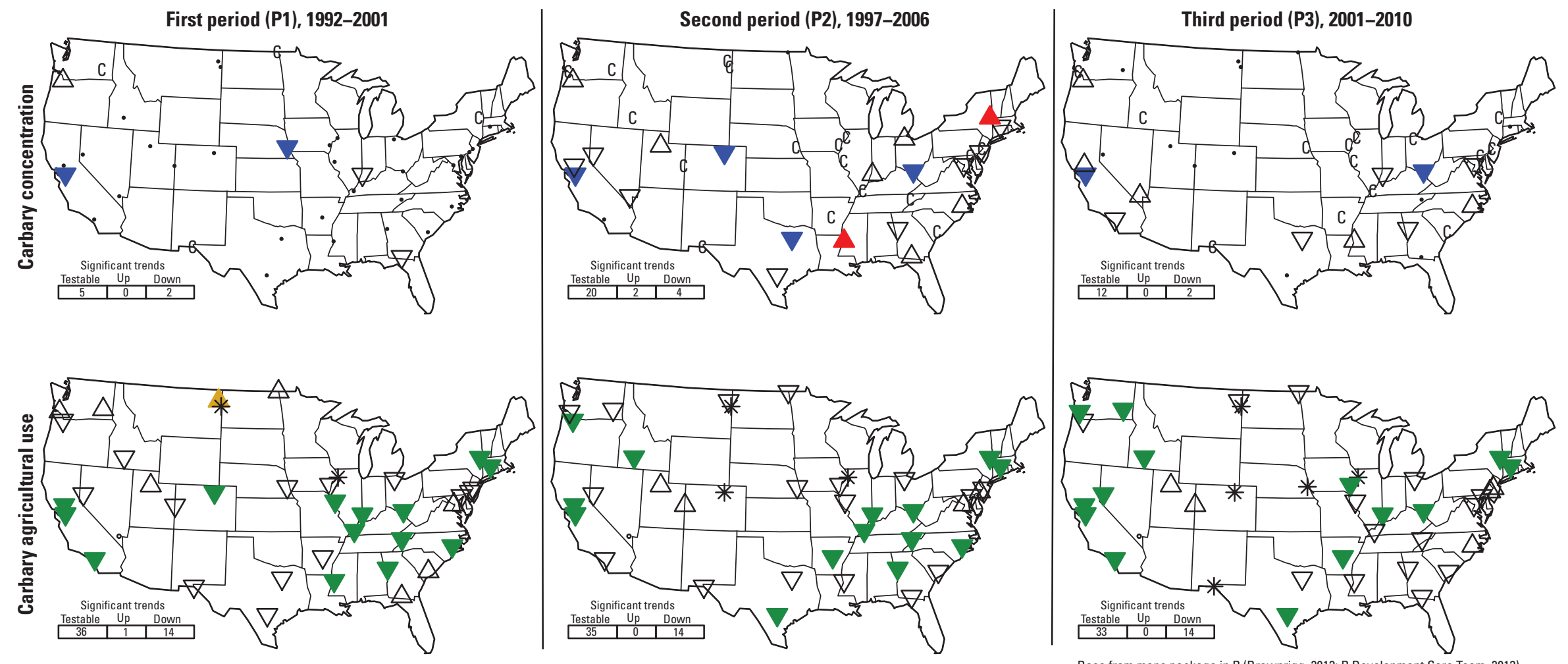

EXPLANATION

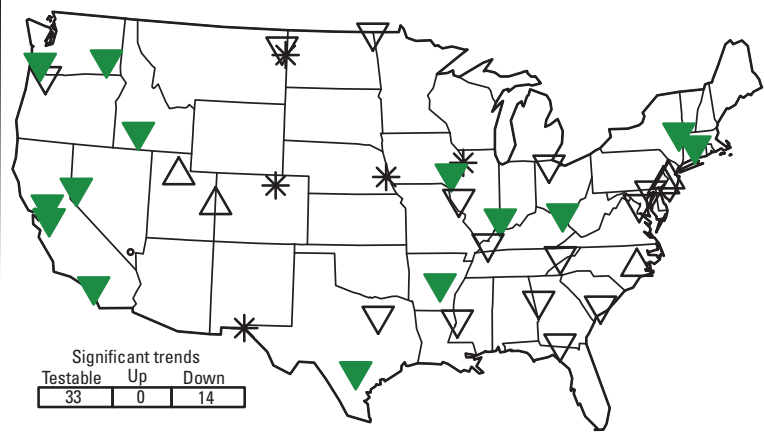
Base from maps package in $\mathrm{R}$ (Brownrigg, 2013; R Development Core Team, 2013)
Eisenlohr projection

\begin{tabular}{|c|c|c|c|c|c|}
\hline \multirow{6}{*}{ 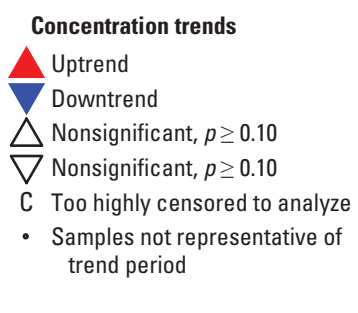 } & \multirow{6}{*}{ 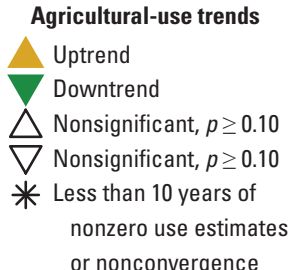 } & \multicolumn{4}{|c|}{$\begin{array}{l}\text { Significant concentration and use } \\
\text { trends at matching sites }\end{array}$} \\
\hline & & & & & \\
\hline & & & & & \\
\hline & & 0 & 0 & & \\
\hline & & & $\frac{2}{1}$ & & \\
\hline & & & & & \\
\hline
\end{tabular}

Figure 18. Carbaryl concentration and agricultural-use trends at independent trend sites, 1992-2010. 


\section{Nested Basin Analysis for the Mississippi River Basin}

As another perspective on trend results, this section presents a more detailed assessment of concentration and use trends for simazine, metolachlor, atrazine and DEA, and diazinon for a set of 17 nested sites in the Mississippi River Basin that represent the contributions of flow and pesticides from major subbasins and their internal tributaries. The sites used for this analysis consist of sites in the Midwest Region (fig. 2) that had sufficient data to analyze concentration trends for both the second and third periods. The 17 sites (indicated by an "N" in the "Trend analyses" column of table 1) are comprised of 6 sites in the Ohio River Basin (OHIO-GU, OHIOCA, WHITE, WABASH, TENNS, OHIO-GRCH), 4 sites in the Upper Mississippi River Basin (MSSP-CL, IOWA-WAP, ILLI-VC, MSSP-GR), 3 sites in the Missouri River Basin (MIZZ-OM, PLATTE, MIZZ-HE), 1 site on the Mississippi River downstream from the confluence of the Upper Mississippi and Missouri Rivers (MISS-TH), 2 sites on tributaries to the Lower Mississippi River (ARKNS, YAZOO), and then a final site on the Mississippi River upstream of the outlet to the Gulf of Mexico (MSSP-SF). The nested design facilitates an upstream-to-downstream interpretation of the causes of trends and the inter-relations among sites. In particular, the approach evaluates the degree to which the combined effects of various tributaries make sense for explaining downstream trends.

Nested trends were analyzed using a consistent graphical format, as shown in figure 19 for simazine for the second (1997-2006) and third (2001-10) periods. To illustrate uncertainty in the fitted trends, 90-percent confidence intervals are shown. A confidence interval with an upper bound less than zero indicates a significant downtrend, an interval with a lower bound greater than zero indicates a significant uptrend, and an interval that overlaps zero indicates a nonsignificant trend. When comparing concentration and agricultural-use trends, if the respective confidence intervals do not overlap the concentration trend was deemed to be significantly different than the use trend. For example, in figure 19 there is a significant simazine concentration uptrend for TENNS (table 5) for 1997-2006 and the uptrend is larger than the use trend (which is not statistically significant). Assuming the errors from the concentration model are uncorrelated with the errors from the use-trend model, one would expect about 20 percent ( 1 out of 5) of the pairwise comparisons to be significantly different by chance, even if there is no difference between the concentration and use trends. Therefore, nonoverlapping intervals indicate likelihood, but not conclusive evidence, that the trends differ. The nested structure of the basins is indicated on the left-hand side of the graph (figs. 19-23) along with the relative streamflow and pesticide concentration for each site. For example, flow for the main stem site on the lower Mississippi, MSSP-SF (table 1), consists of a substantial contribution from the upstream site MSSP-TH (which includes the Missouri and Upper Mississippi Rivers), a somewhat larger contribution from the Ohio River (OHIO-GRCH), and smaller local contributions from tributaries ARKNS and YAZOO (as well as other unmonitored tributaries).

At the largest scale, trends observed at MSSP-SF, the site farthest downstream on the Mississippi River, reflect influences from the Ohio River Basin, the Upper Mississippi and Missouri River Basins, and tributaries to the Lower Mississippi River (fig. 2, table 1). For each of the pesticides evaluated below, the consistency of concentration and use trends is considered at both this largest scale and within each subbasin. Each of the pesticides evaluated has its own unique combination of effects on trends, including total amount of use, different trends in agricultural use, and varying contributions from nonagricultural uses.

\section{Simazine}

Simazine concentration and use trends for the nested basins are shown in figure 19. Simazine is widely used on corn, with mostly increasing agricultural use during 1997-2006 and then mostly level to decreasing use during 2001-10 (fig. 3). It also has substantial use for nonagricultural purposes, so agricultural-use trends analyzed in this study tell only part of the story. As noted earlier, Ryberg and others (2010) detected many significant uptrends in simazine concentration for urban streams nationwide during similar periods (1996-2004 and 2000-2008), suggesting that nonagricultural uses have been increasing.

During 1997-2006, simazine had uptrends in concentrations at the farthest downstream site on the Mississippi River, MSSP-SF, and all three of the major contributing subbasins upstream, MIZZ-HE, MSSP-GR, and OHIO-GRCH. Of these sites, use trends could only be analyzed for OHIO-GRCH, for which the trend was upward, but not significant. Overall, 12 of the 17 sites had significant uptrends in simazine concentrations.

Trend results for tributary sites were consistent with major subbasin trends during 1997-2006, except for the Missouri River Basin. Four of the five sites in the Ohio River Basin upstream from OHIO-GRCH also had significant uptrends in concentrations, including two rivers with significant uptrends in use - the heavily agricultural Wabash and White Rivers. Only the less developed upper portion of the Ohio River Basin at OHIO-GU did not have a significant uptrend in concentration. The Upper Mississippi River Basin had a more mixed pattern, with uptrends at the downstream site at MSSP-GR and a major tributary, the Illinois River at ILLI-VC, which also had an uptrend in use. There was a nonsignificant trend for the Iowa River, IOWA-WAP, and a downtrend for the farthest upstream site, MSSP-CL, but both these sites had low simazine concentrations. The Missouri River Basin also had a mixed pattern, with upstream sites having a nonsignificant trend at MIZZ-OM and a significant downtrend at PLATTE, but a significant uptrend at the downstream site at MIZZ-HE. The results for the Missouri River Basin indicate 


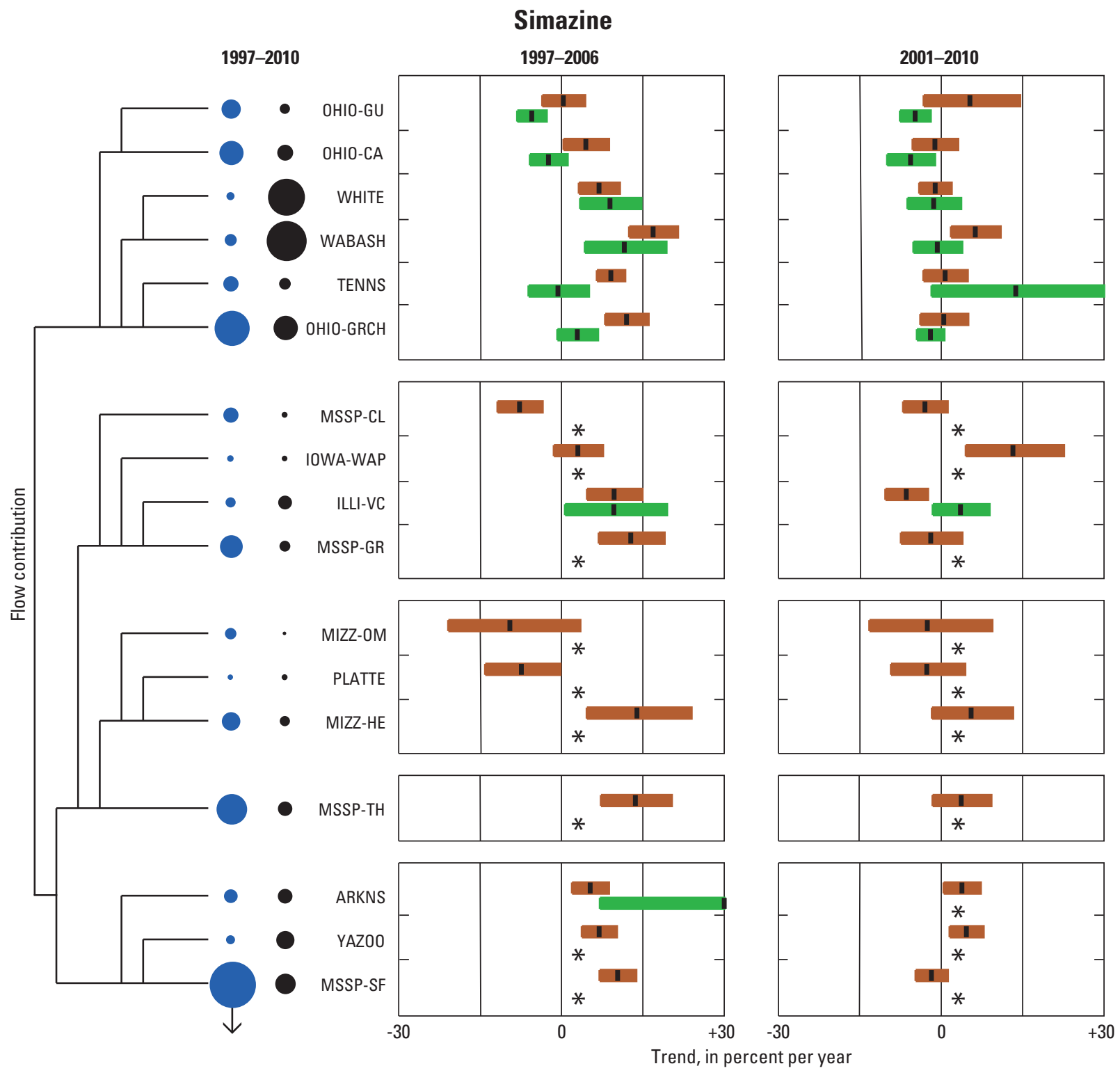

EXPLANATION

$\begin{array}{lll}\begin{array}{c}\text { Average daily streamflow, } \\ \text { in cubic meters per } \\ \text { second }\end{array} & \begin{array}{c}\text { Average daily } \\ \text { concentration, in } \\ \text { micrograms per liter }\end{array} & \begin{array}{l}\text { 90-percent confidence limits } \\ \text { Concentration trend }\end{array} \\ 4,000 & 0.025 & \begin{array}{l}\text { Agricultural-use trend } \\ \text { Estimated value }\end{array} \\ 4,000 & 0.1 & * \begin{array}{l}\text { Less than } 10 \text { years of } \\ \text { nonzero use estimates or } \\ \text { nonconvergence }\end{array} \\ 16,000 & 0.4 & \end{array}$

Figure 19. Simazine concentration and agricultural-use trends for nested basins in the Mississippi River Basin for 1997-2006 and 2001-10. The main-stem site on the lower Mississippi River, MSSP-SF, consists of local flow and pesticide load contributions from tributaries, YAZOO and ARKNS, a larger contribution from the Ohio River (OHIO-GRCH), and a substantial contribution from the upstream site MSSP-TH (which includes the Missouri and Upper Mississippi Rivers). 
the likelihood of simazine sources from urban or agricultural areas downstream from the MIZZ-OM and PLATTE sites. The uptrends at the outlets of the Upper Mississippi River (MSSPGR) and the Missouri River (MIZZ-HE) were similarly evident downstream on the Mississippi River at both MSSP-TH and MSSP-SF.

During 2001-10, the overall pattern of predominantly uptrends in simazine concentrations observed during 19972006 shifted to mainly nonsignificant trends. Overall, there were 12 of 17 sites with nonsignificant trends. Simazine had nonsignificant trends at the farthest downstream site on the Mississippi, MSSP-SF and the downstream sites of all three of the major contributing subbasins upstream, MIZZ-HE, MSSPGR, and OHIO-GRCH. Of these sites, use trends could only be analyzed for OHIO-GRCH, for which the trend was also nonsignificant.

Trend results for tributary sites were consistent with the nonsignificant trends for all major subbasins during 2001-10. Four of the five sites in the Ohio River Basin upstream from OHIO-GRCH also had nonsignificant trends in concentrations, with only the Wabash River having a significant uptrend. The Upper Mississippi River Basin had a more mixed pattern, as it did in the previous period. There were nonsignificant trends at the downstream site at MSSP-GR and the farthest upstream site, MSSP-CL, but the intervening tributaries had opposite trends, with the Illinois River at ILLI-VC having a significant downtrend and the Iowa River at IOWA-WAP having a significant uptrend. The Missouri River Basin had nonsignificant trends at all sites. The nonsignificant trends at the outlets of the Upper Mississippi River (MSSP-GR) and the Missouri (MIZZ-HE) were similarly evident downstream on the Mississippi River at both MSSP-TH and MSSP-SF.

Average daily simazine concentration (estimated by averaging the fitted daily concentrations from the SEAWAVE-Q model) for the Ohio River sites ranges from about $0.4 \mu \mathrm{g} / \mathrm{L}$ for WABASH to about $0.025 \mu \mathrm{g} / \mathrm{L}$ for OHIO-GU and TENNS and for the other sites concentrations ranged from about 0.1 to less than $0.025 \mu \mathrm{g} / \mathrm{L}$. The average concentrations for downstream sites can be roughly interpreted as a flow-weighted average of concentrations for upstream sites and concentrations from ungaged intervening basin areas. For example, OHIO-GU contributes about one-half of the flow, on average, for OHIO$\mathrm{CA}$ and about one-half of the flow is from intervening sources. Because the average concentration for OHIO-CA is large compared to OHIO-GU, the intervening sources have higher simazine concentration than OHIO-GU. Flow for OHIOGRCH consists of a large contribution from OHIO-CA and TENNS, both of which have relatively low concentrations; a small contribution from WABASH, which has much higher concentration; and other ungaged contributions with unknown concentration. The concentration for OHIO-GRCH is between the low concentrations for OHIO-CA and TENNS and the high concentration for WABASH.

\section{Metolachlor}

Metolachlor concentration and use trends for the nested basins are shown in figure 20. Unlike simazine, which has substantial agricultural and nonagricultural uses, the primary use of metolachlor is on corn (fig. 3). Consequently, there is almost complete agreement between the metolachlor concentration trends and agricultural-use trends for both periods. Downtrends are prevalent during 1997-2006, during which the amount of active ingredient used reduced greatly, and nonsignificant and mixed trends are prevalent during 2001-10, which is mostly after the largest reductions in use had already occurred.

During 1997-2006, metolachlor had downtrends in concentrations at the farthest downstream site on the Mississippi River, MSSP-SF, and two of the major contributing subbasins upstream, MSSP-GR and OHIO-GRCH. The Missouri River at MIZZ-HE had a nonsignificant trend, but after flowing into the Mississippi River together with the Upper Mississippi River, MSSP-GR, the downstream site at MSSP-TH had a significant downtrend. Use trends were significantly downward in all major subbasins and for the entire Mississippi River Basin. Overall, considering all trend assessment sites in the Mississippi River Basin, 13 of 17 had significant downtrends in both concentration and use.

Trend results for tributary sites were consistent with the downtrends for all major subbasins during 1997-2006. All sites in the Ohio River Basin and all sites in the Upper Mississippi River Basin had significant downtrends in both concentrations and use. In the Missouri basin, the farthest upstream site had a nonsignificant concentration trend, while PLATTE (table 1) had a downtrend - and there were significant use downtrends at all Missouri River Basin sites.

During 2001-10, the dominant pattern of downtrends in metolachlor concentrations observed during 1997-2006 throughout the Mississippi River Basin shifted to mainly nonsignificant trends. Considering all trend assessment sites in the Mississippi River Basin, 11 of 17 had nonsignificant trends in concentration. Metolachlor had nonsignificant concentration trends at the farthest downstream site on the Mississippi, MSSP-SF, and at the downstream sites of all three of the major contributing subbasins-MIZZ-HE, MSSP-GR, and OHIO-GRCH. At all of these sites, use trends were also either nonsignificant or unassessable.

Patterns were more complicated within each subbasin during 2001-10, but overall consistent with the nonsignificant trends at subbasin outlets. Four of the five sites in the Ohio River Basin upstream from OHIO-GRCH also had nonsignificant trends in concentrations, but TENNS had a significant uptrend. The Upper Mississippi River Basin had a more mixed pattern, as it did in the previous period. Although there was a nonsignificant trend at the downstream site at MSSP-GR, the farthest upstream site (MSSP-CL) had an uptrend, and the 


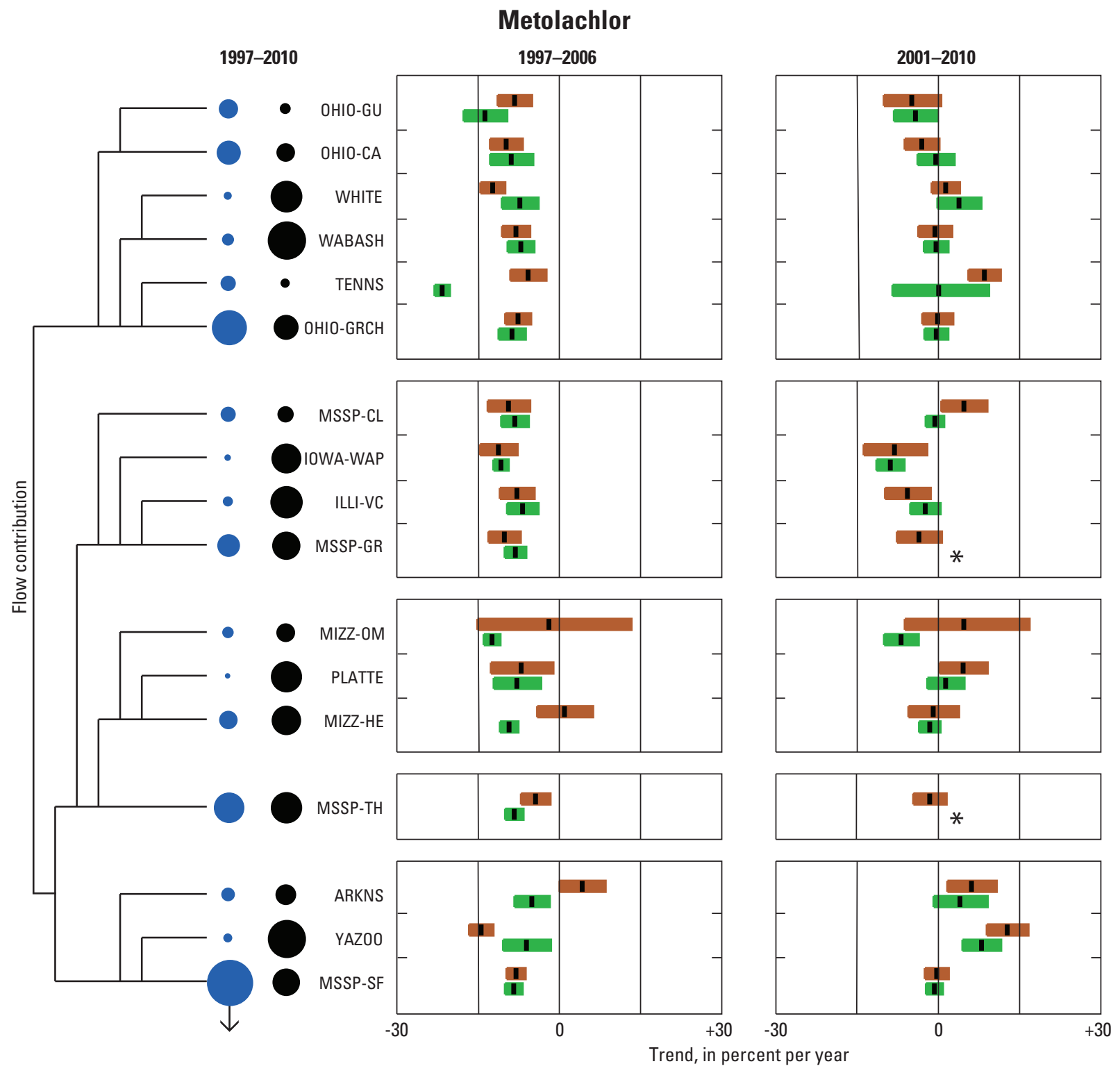

EXPLANATION

$\begin{array}{lll}\begin{array}{l}\text { Average daily streamflow, } \\ \text { in cubic meters per } \\ \text { second }\end{array} & \begin{array}{c}\text { Average daily } \\ \text { concentration, in } \\ \text { micrograms per liter }\end{array} & \begin{array}{l}\text { 90-percent confidence limits } \\ \text { Concentration trend }\end{array} \\ 1,000 & 0.025 & \begin{array}{l}\text { Agricultural-use trend } \\ \text { Estimated value }\end{array} \\ 4,000 & 0.1 & * \quad \begin{array}{l}\text { Less than } 10 \text { years of } \\ \text { nonzero use estimates or } \\ \text { nonconvergence }\end{array} \\ 16,000 & 0.4 & \end{array}$

Figure 20. Metolachlor concentration and agricultural-use trends for nested basins in the Mississippi River Basin for trend periods 2, 1997-2006, and 3, 2001-10. The main-stem site on the lower Mississippi River, MSSP-SF, consists of local flow and pesticide load contributions from tributaries, YAZOO and ARKNS, a larger contribution from the Ohio River (OHIO-GRCH), and a substantial contribution from the upstream site MSSP-TH (which includes the Missouri and Upper Mississippi Rivers). 
Illinois River at ILLI-VC and the Iowa River at IOWA-WAP both had significant downtrends in concentration. Although the MSSP-GR trend was nonsignificant, it was downward and consistent in magnitude and direction with the influences of the upstream sites. The Missouri River Basin had nonsignificant trends at the farthest upstream and downstream sites on the Missouri, but PLATTE had a significant uptrend. In the Lower Mississippi River Basin, both ARKNS and YAZOO had significant uptrends in concentration, although their flows are small compared to the Mississippi River. Of the six sites with significant concentration uptrends or downtrends, none had significantly different use trends.

\section{Atrazine and Deethylatrazine}

Concentration and use trends for atrazine and DEA are shown in figures 21 and 22 (use trends for atrazine are shown for both compounds). Concentration trends for atrazine and DEA are considered jointly because a substantial part of the atrazine applied to fields degrades to DEA before making its way to streams. A detailed mass-balance accounting of atrazine and DEA is beyond the scope of this study, but qualitative comparison of the trends are used when possible to understand possible explanations for differing trends between atrazine and DEA. Although, like metolachlor, most atrazine is used on corn acreage, changes in use have been much less than for metolachlor (fig. 3). During both 1997-2006 and 2001-10, atrazine concentration trends at study sites were a mixture of relatively small but significant downtrends and nonsignificant trends. Notably, there were no significant uptrends in either period. Concentration trends for DEA differed from atrazine in that both periods had a number of sites with significant uptrends.

During 1997-2006, atrazine had downtrends in concentrations at the farthest downstream site on the Mississippi River at MSSP-SF and at the outlet of the Upper Mississippi River at MSSP-GR, but nonsignificant trends for the Ohio River at OHIO-GRCH and the Missouri River at MIZZ-HE (fig. 21). These concentration trends were generally consistent with use trends, which were significantly downward (but small, less than 5 percent per year), or nonsignificant in all major subbasins and their tributary basins, as well as for the entire Mississippi River Basin. Trends in DEA concentrations (fig. 22) were similar to atrazine for the Ohio River Basin, but markedly different for the Upper Mississippi and Missouri Rivers. There were significant uptrends in DEA concentrations at MSSP-GR and MIZZ-HE despite stable or declining use of atrazine. As mentioned in the "National Analysis of Independent Trend Sites" section, these uptrends in DEA could be caused by some factor, such as a management practice, that has increased over time the proportion of applied atrazine that runs off to streams as DEA, or by a transport pathway for DEA, such as groundwater, that has multiyear lags between use and arrival at a stream.
Trends at tributary sites within the major subbasins were consistent with this large-scale pattern during 1997-2006. Sites in the Ohio River Basin had the greatest consistency in atrazine and DEA concentration trends, with none of the sites having significant differences between the magnitudes of atrazine and DEA trends; however, in the Upper Mississippi Basin, the Iowa River at IOWA-WAP had a significant downtrend in atrazine concentrations, but an uptrend in DEA. In the Missouri River Basin, the farthest upstream site at MIZZ-OM had a nonsignificant atrazine concentration trend, but a significant uptrend in DEA, whereas the Platte River had a significant downtrend in atrazine, but a nonsignificant trend in DEA.

During 2001-10, atrazine concentration trends and use trends were very similar to 1997-2006 for both major subbasins and the downstream site on the Mississippi River, and for most tributary sites (fig. 21). One difference between the periods was that five sites-WHITE, MSSP-CL, IOWA-WAP, MSSP-GR, and YAZOO - all changed from having atrazine concentration trends significantly more downward than use trends, to concentration and use downtrends that were not significantly different. Possible reasons for this pattern, among several, could be increased effectiveness of nonuse-management practices during the first period, followed by a period of no further increases in implementation, or a systematic change in use data. Only one site, ILL-VC, shifted from no significant difference between concentration and use trend for 1997 2006, to a downtrend in concentration during 2001-10.

In the Ohio River Basin, trends in DEA concentrations for 2001-10, compared to 1997-2006, generally shifted from downward or nonsignificant, to nonsignificant or upward (fig. 22). This followed the general direction of changes observed for atrazine. In the Upper Mississippi basin, results were mixed, with MSSP-CL changing from a downtrend to an uptrend in concentration, despite a strong reduction in use of atrazine, and with MSSP-GR changing from an uptrend in the first period to a downtrend. Results were similarly mixed for the Missouri River Basin, with the upstream site at MIZZ-OM continuing about the same magnitude of uptrend from trend period 2 to trend period 3, but PLATTE changing from nonsignificant to a significant uptrend, and the MIZZ-HE going the other way, from an uptrend to nonsignificant. The pattern of mixed results for tributaries continued in the Lower Mississippi River, where ARKNS had a significant uptrend in DEA concentrations from 1997-2006 and a nonsignificant trend from 2001-10, but YAZOO changed from a nonsignificant trend to an uptrend.

Although the site-by-site results, considering the combination of periods and both atrazine and DEA, indicate a wide range of conditions among individual tributaries, the big picture is relatively consistent. For atrazine, 11 of 17 sites had significant concentration downtrends in one or both periods, and most were accompanied by significant downtrends in use. This pattern held down through the nested outlets of subbasins 


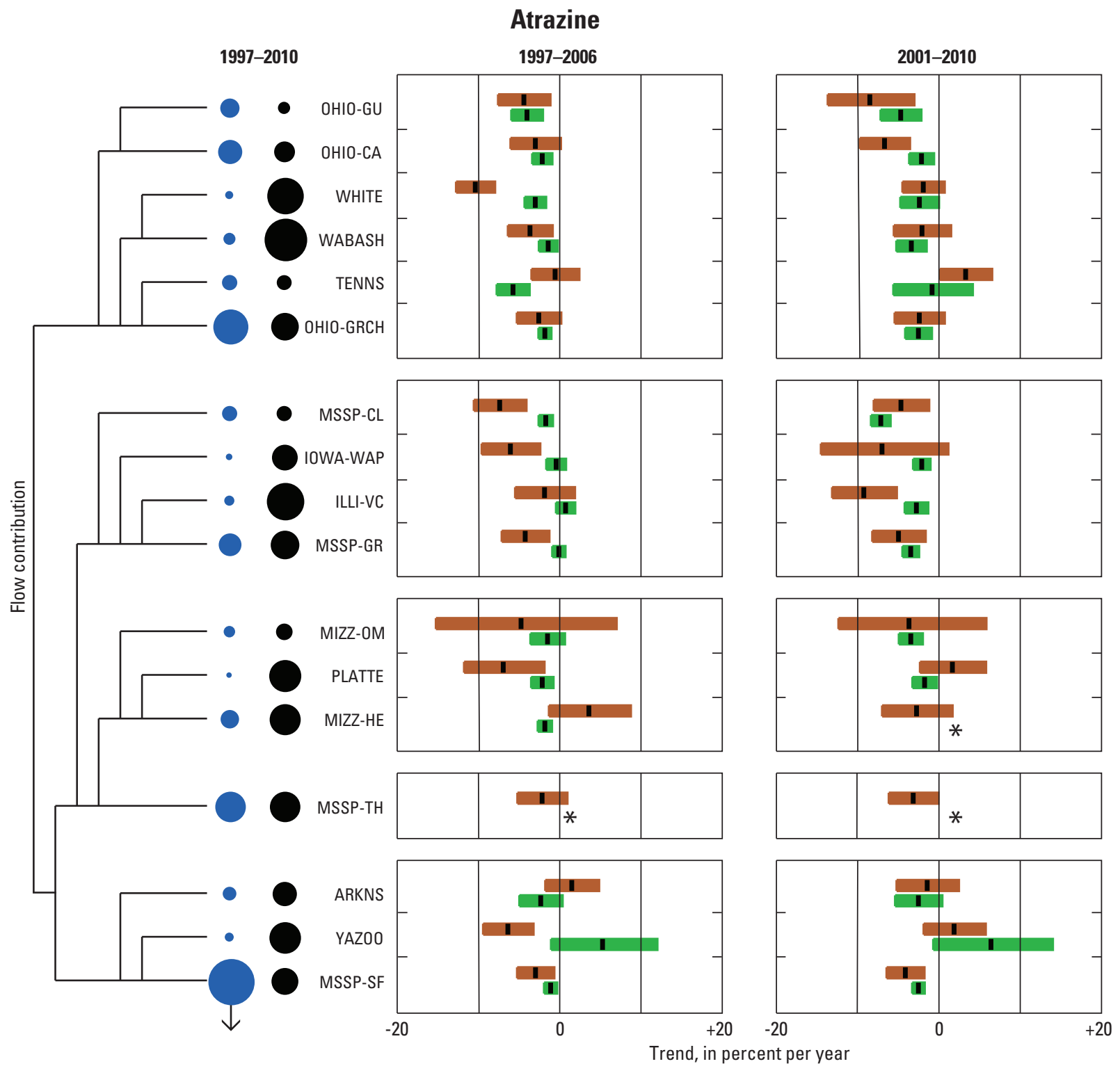

EXPLANATION

$\begin{array}{lll}\begin{array}{l}\text { Average daily streamflow, } \\ \text { in cubic meters per } \\ \text { second }\end{array} & \begin{array}{c}\text { Average daily } \\ \text { concentration, in } \\ \text { micrograms per liter }\end{array} & \begin{array}{c}\text { 90-percent confidence limits } \\ \text { Concentration trend }\end{array} \\ 1,000 & 0.075 & \begin{array}{l}\text { Agricultural-use trend } \\ \text { Istimated value }\end{array} \\ 16,000 & 0.3 & * \quad \begin{array}{l}\text { Less than } 10 \text { years of } \\ \text { nonzero use estimates or } \\ \text { nonconvergence }\end{array} \\ & 1.2 & \end{array}$

Figure 21. Atrazine concentration and agricultural-use trends for nested basins in the Mississippi River Basin for trend periods 2, 1997-2006, and 3, 2001-10. The main-stem site on the lower Mississippi River, MSSP-SF, consists of local flow and pesticide load contributions from tributaries, YAZOO and ARKNS, a larger contribution from the Ohio River (OHIO-GRCH), and a substantial contribution from the upstream site MSSP-TH (which includes the Missouri and Upper Mississippi Rivers). 


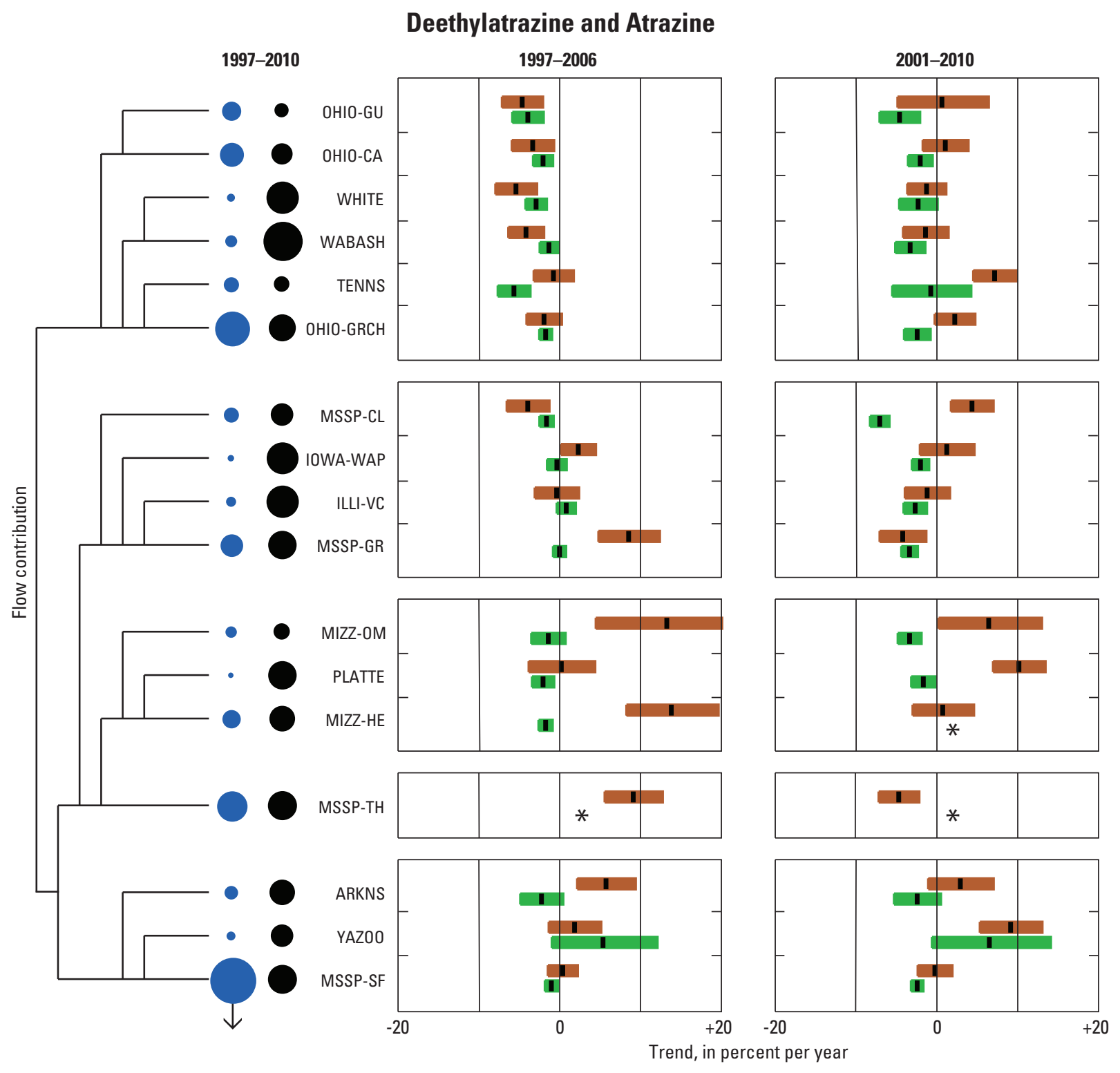

EXPLANATION

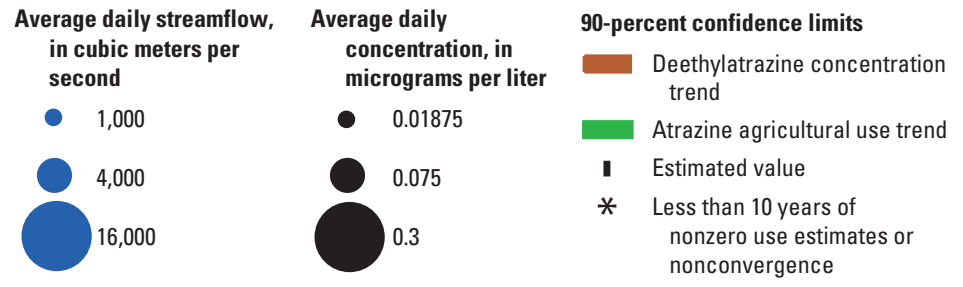

Figure 22. Deethylatrazine concentration and atrazine agricultural-use trends for nested basins in the Mississippi River Basin for trend periods 2, 1997-2006, and 3, 2001-10. The main-stem site on the lower Mississippi River, MSSP-SF, consists of local flow and pesticide load contributions from tributaries, YAZOO and ARKNS, a larger contribution from the Ohio River (OHIO-GRCH), and a substantial contribution from the upstream site MSSP-TH (which includes the Missouri and Upper Mississippi Rivers). 
and the farthest downstream site on the Mississippi River, MSSP-SF, had small but significant concentration and use downtrends during both 1997-2006 and 2001-10. In comparison, DEA concentrations trended upward during one or both periods at 10 of the 17 sites, but trends were more varied at the large-flow sites, and MSSP-SF had no significant trend in either period.

\section{Diazinon}

Diazinon concentration and use trends for the nested basins are shown in figure 23. Like simazine, diazinon has much lower agricultural use in the Mississippi River Basin than atrazine and metolachlor, and a history of substantial nonagricultural use. Different from simazine, diazinon use in urban areas was phased out during 2001-04, which is in the last one-half of period 2 and the first one-half of period 3. Diazinon was also largely phased out of agricultural use in the Mississippi River Basin. Consequently, downtrends in diazinon concentrations were found at every assessable site in both 1997-2006 and 2001-10, with all but two being statistically significant.

During 1997-2006, diazinon had downtrends in concentrations at the farthest downstream site on the Mississippi, MSSP-SF, and all three of the major contributing subbasins upstream, MIZZ-HE, MSSP-GR, and OHIO-GRCH. All had agricultural-use trends of similar magnitude. Three of the five sites in the Ohio River Basin upstream from OHIO-GRCH also had significant downtrends in concentrations. The Upper Mississippi and Missouri River Basins had similar patterns, with downtrends in contributing subbasins, IOWA-WAP, ILLI-VC, and PLATTE. The downtrends at the outlets of the Upper Mississippi River (MSSP-GR) and the Missouri River (MIZZ-HE) were similarly evident downstream on the Mississippi River at both MSSP-TH and MSSP-SF.

During 2001-10, the overall pattern of predominantly downtrends in diazinon concentrations observed during 1997-2006 continued, but trends at most sites became more steeply downward or unassessable, as frequencies on undetectable concentrations increased. Few sites had adequate use data to evaluate for trends. Although many of the use downtrends were not significant, diazinon has substantial nonagricultural use and these uses were phased out beginning in 2000 (U.S. Environmental Protection Agency, 2008c). Total use probably declined more rapidly than agricultural use.

\section{Conclusions}

Pesticide concentrations in major rivers were assessed at 59 sites for 40 pesticides and pesticide degradates, during each of three overlapping periods: 1992-2001, 1997-2006, and 2001-10. In addition to trends in concentration, trends in agricultural use were assessed at 57 major river sites for 35 parent compounds with agricultural uses, during the same three periods. The SEAWAVE-Q model was used to assess trends in concentration, and trends in agricultural use were assessed by using a parametric survival regression model for interval-censored data.

Trends were calculated for all period/site/pesticide combinations, referred to as cases, for which there were sufficient data. Out of 7,080 possible concentration trend cases, there were adequate data to evaluate trends for 1,003 concentration trends. Out of 5,985 possible agricultural-use trend cases, there were adequate data to find a solution for 2,413 use trends. Trend results for concentrations and use are provided in online Microsoft Excel ${ }^{\mathrm{TM}}$ files so that readers can use filters and tools to make their own detailed comparisons.

For the most frequently detected pesticides, two types of detailed graphical and numerical analyses provide interpretation of the patterns and potential causes of the trends. The first type is a national analysis of independent, non-nested trend sites. The second type is a nested basin analysis for the Mississippi River Basin. For the first analysis, a subset of 39 sites was chosen to represent non-nested, relatively independent basins. The pesticides in this analysis include simazine, prometon, cyanazine, metolachlor, atrazine and its degradation product deethylatrazine (DEA), alachlor, tebuthiuron, Dacthal, pendimethalin, chlorpyrifos, malathion, diazinon, fipronil and its degradation product desulfinylfipronil, carbofuran, and carbaryl. For the second analysis, a more detailed assessment of concentration and use trends was developed for the second and third periods for simazine, metolachlor, atrazine and DEA, and diazinon, for a set of 17 nested sites in the Mississippi River Basin. The 17 sites, which represent the contributions of flow and pesticides from major subbasins and their internal tributaries, are comprised of 6 sites in the Ohio River Basin, 4 sites in the Upper Mississippi River Basin, 3 sites in the Missouri River Basin, 1 site on the Mississippi downstream from the confluence of the Upper Mississippi and Missouri Rivers, 2 sites on tributaries to the Lower Mississippi River, and then a final site on the Mississippi River upstream from the outlet to the Gulf of Mexico. The nested design facilitates interpretation of the causes of trends and highlights the inter-relations among tributary sites and the largest rivers.

The findings and interpretation of trends for each pesticide, which are provided in the "Trend Results," "National Analysis of Independent Trend Sites," and "Nested Basin Analysis for the Mississippi River Basin" sections, collectively lead to several more broadly significant conclusions:

- Pesticides strongly dominated by agricultural usecyanazine, metolachlor, atrazine, and alachlor-had widespread agreement between concentration trends and agricultural-use trends. For the 39 independent sites, of 163 cases for which the concentration and use trends were both assessable, 54 had significant concentration and use trends in the same direction, compared to only 6 in opposite directions. Other testable cases had nonsignificant trends for either concentration or use, or both. Similarly, the nested site analysis of metolachlor and atrazine in the Mississippi River Basin 


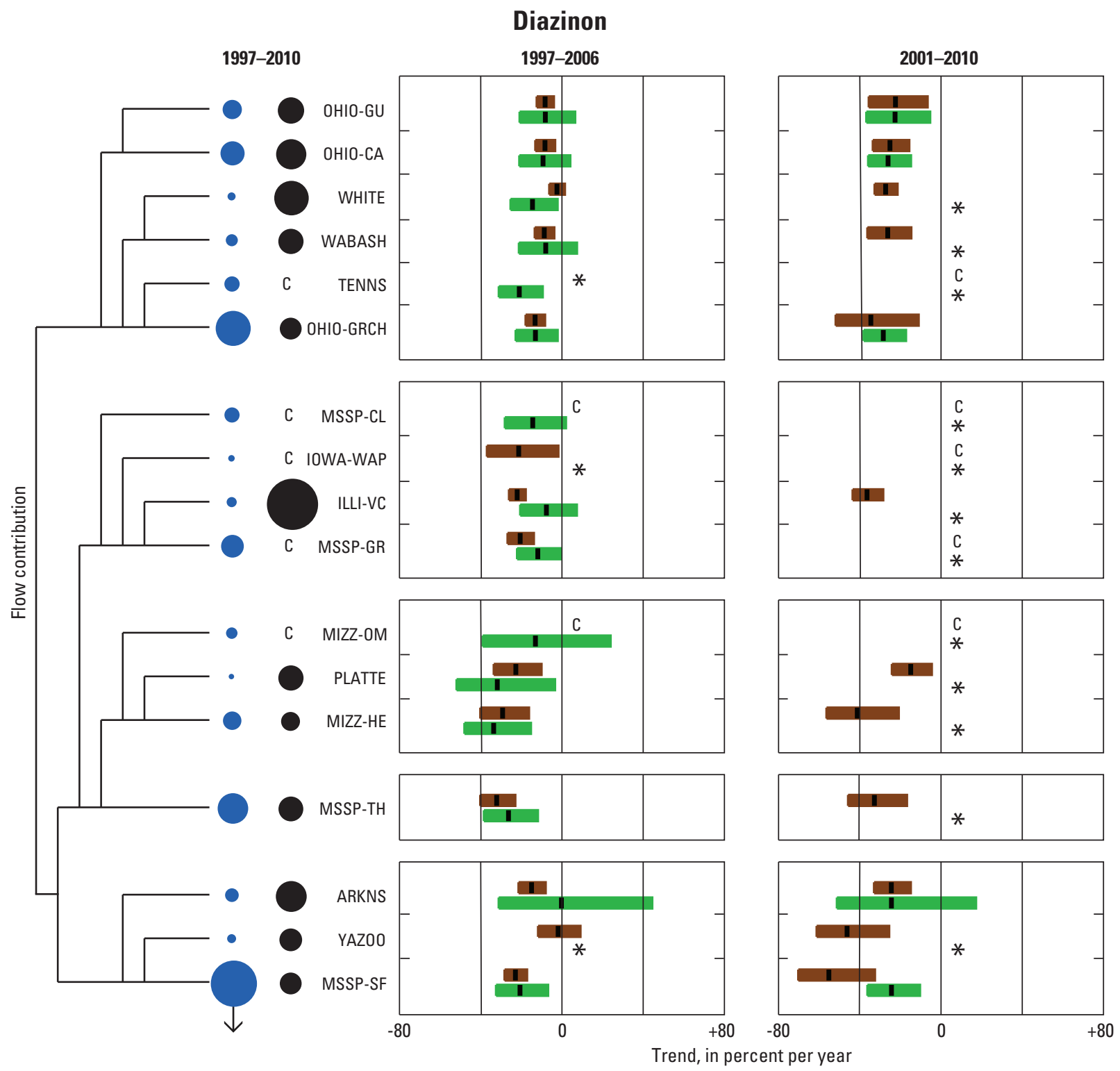

\section{EXPLANATION}

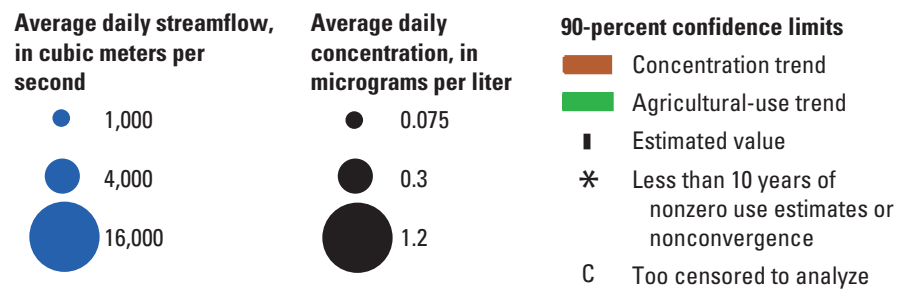

Figure 23. Diazinon concentration and agricultural-use trends for nested basins in the Mississippi River Basin for trend periods 2, 1997-2006, and 3, 2001-10. The main-stem site on the lower Mississippi River, MSSP-SF, consists of local flow and pesticide load contributions from tributaries, YAZOO and ARKNS, a larger contribution from the Ohio River (OHIO-GRCH), and a substantial contribution from the upstream site MSSP-TH (which includes the Missouri and Upper Mississippi Rivers). 
showed that only 4 of 32 possible direct comparisons of use and concentration trends for metolachlor had significant differences in trends ( 3 with concentrations increasing more than use and 1 with concentration decreasing more than use, and all in the 1997-2006 period). Results for atrazine showed that only 6 of 31 possible comparisons had significant differences (all with concentrations decreasing more than use and 5 of them in the 1997-2006 period).

- Pesticides with substantial use in both agricultural and urban applications - simazine, tebuthiuron, Dacthal, pendimethalin, chlorpyrifos, malathion, diazinon, fipronil, carbofuran, and carbaryl — had concentration trends that were mostly explained by a combination of agricultural-use trends and concentration trends in urban streams, which were evaluated in a separate companion study. The importance of the urban stream trends for explaining concentration trends in major rivers indicates the significance of nonagricultural uses of some pesticides to concentrations in major rivers despite the much smaller area of urban land use compared to agriculture.

- Deethylatrazine (DEA, a degradate of atrazine) was the only pesticide compound assessed that had frequent occurrences during 1997-2006 and 2001-10 of concentration trends in the opposite direction of use trends (atrazine use). In all 10 cases of statistically significant opposing trends found in the independent site analysis, DEA had a concentration uptrend, whereas the use trend was downward. The nested site analysis of the Mississippi River Basin showed that 10 of 31 comparisons of use and concentration trends had concentrations increasing significantly more than use. The occurrence of uptrends in DEA concentrations for sites and periods with significant downtrends in both the use and concentrations of atrazine could be caused by some factor, such as a management practice, that has increased over time the proportion of applied atrazine that runs off to streams as DEA, or by a transport pathway for DEA, such as groundwater, that has multiyear lags between use and arrival at a stream.

- Analyses of concentration trends for simazine, metolachlor, atrazine and DEA, and diazinon for the hydrologically nested sites in the Mississippi River Basin show that most trends observed in the largest riversmultiple Mississippi River sites, the Ohio River, and the Missouri River - are consistent with streamflow contributions and concentration trends observed at tributary sites.

Streamflow (incorporated into the trend model and shown in the nested basin analysis) and trends in agricultural use of pesticides (quantified in this report) and urban use of pesticides (represented by concentration trends in a companion study of urban streams) are all important influences on pesticide concentrations in streams and rivers. Consideration of these influences is vital to understanding trends in pesticide concentrations.

\section{Acknowledgments}

The authors thank Julia Norman, U.S. Geological Survey (USGS) National Water-Quality Assessment (NAWQA) Contaminant Support Team, for providing much of the information in table 3, Nancy Baker, USGS NAWQA National Monitoring and Status Assessment Team for geographic information system support and figures 1 and 3, and James Falcone (USGS NAWQA Surface-Water Trends Team) for geographic information system support. The authors acknowledge the improvements made to the manuscript thanks to the reviews done by Hank Johnson, USGS NAWQA Surface-Water Trends Team, and Nancy Baker.

\section{References Cited}

Baker, N.T., and Stone, W.W., 2013, Preliminary estimates of annual agricultural pesticide use for counties of the conterminous United States, 2010-11: U.S. Geological Survey Open-File Report 2013-1295, 2-p. pamphlet, 14 tables, accessed February 3, 2014, at http://dx.doi.org/10.3133/ ofr20131295.

Brownrigg, Ray, 2013, maps-Draw geographical maps: R package version 2.3-2, accessed July 22, 2014, at http://CRAN.R-project.org/package $=$ maps

Cavalier, T.C., Lavy, T.L., and Mattice, J.D., 1991, Persistence of selected pesticides in ground-water samples: Ground Water, v. 29, no. 2, p. 225-231.

Connelly, Pete, 2001, Environmental fate of fipronil: Sacramento, California Department of Pesticide Regulation, 17 p.

Crawford, C.G., 2004, Sampling strategies for estimating acute and chronic exposures of pesticides in streams: Journal of the American Water Resources Association, v. 40, no. 2 , p. $485-502$.

Edwards, T.K., and Glysson, G.D., 1999, Field methods for measurement of fluvial sediment: U.S. Geological Survey Techniques of Water-Resources Investigations, book 3, chapter C2, 89 p. [Also available at http://pubs.er.usgs.gov/ usgspubs/twri/twri03C2.]

Florida Department of Health, 2011, Chemicals in private drinking water wells: Dieldrin Fact Sheet, 2 p., accessed July 18, 2013, at http://www.doh.state.fl.us/chd/volusia/EH/ Dieldrin/DieldrinFactSheet.pdf. 
Gan, J., Qang, Q., Yates, S.R., Koskinen, W.C., and Jury, W.A., 2002, Dechlorination of chloroacetanilide herbicides by thiosulfate salts: Proceedings of the National Academy of Sciences, v. 99, no. 8, p. 5,189-5,194.

Gilliom, R.J., Alley, W.M., and Gurtz, M.E., 1995, Design of the National Water-Quality Assessment Program-Occurrence and distribution of water-quality conditions: U.S. Geological Survey Circular 1112, 33 p. [Also available at http://water.usgs.gov/pubs/circ/circ1112/.]

Gilliom, R.J., Barbash, J.E., Crawford, C.G., Hamilton, P.A., Martin, J.D., Nakagaki, Naomi, Nowell, L.H., Scott, J.C., Stackelberg, P.E., Thelin, G.P., and Wolock, D.M., 2006a, The quality of our Nation's waters-Pesticides in the Nation's streams and ground water, 1992-2001: U.S. Geological Survey Circular 1291, 172 p.

Gilliom, R.J., Barbash, J.E., Crawford, C.G., Hamilton, P.A., Martin, J.D., Nakagaki, Naomi, Nowell, L.H., Scott, J.C., Stackelberg, P.E., Thelin, G.P., and Wolock, D.M., 2006b, NAWQA methods for pesticides in water from streams, Appendix 8A of Gilliom, R.J., and others, 2006, The quality of our Nation's waters-Pesticides in the Nation's streams and ground water, 1992-2001: U.S. Geological Survey Circular 1291, Supplemental technical information (available online only), accessed June 14, 2013, at http://water.usgs. gov/nawqa/pnsp/pubs/circ1291/supporting_info.php.

Grube, Arthur, Donaldson, David, Kiely, Timothy, and Wu, La, 2011, Pesticides industry sales and usage-2006 and 2007 market estimates: U.S. Environmental Protection Agency Pesticide Industry Sales and Usage Report EPA 733-R-11001, 33 p., accessed July 11, 2012, at http://www.epa.gov/ opp00001/pestsales/.

Gunasekara, A.S., Truong, Tresca, Kean, S.G., Spurlock, Frank, and Tjeerdema, R.S., 2007, Environmental fate and toxicology of fipronil: Journal of Pesticide Science, v. 32, no. 3, p. 189-199.

Hamaker, J.W., and Thompson, J.M., 1972, Adsorption, in Goring, C.A.I., and Hamaker, J.W., eds., Organic chemicals in the soil environment: New York, Marcel Dekker, v. 1, p. 49-143.

Kiely, T., Donaldson, D., and Grube, A., 2004, Pesticides industry sales and usage-2000 and 2001 market estimates: U.S. Environmental Protection Agency EPA-733-R-04-001, $33 \mathrm{p}$.

Lindley, C.E., Stewart, J.T., and Sandstrom, M.W., 1996, Determination of low concentrations of acetochlor in water by automated solid-phase extraction and gas chromatography with mass-selective detection: Journal of AOAC International, v. 79, no. 4, p. 962-966.
Ma, Q., Rahman, A., Holland, P.T., James, T.K., and McNaughton, D.E., 2004, Field dissipation of acetochlor in two New Zealand soils at two application rates: Journal of Environmental Quality, v. 33, no. 3, p. 930-938.

Mackay, D., Shiu, W-Y., and Ma, K-C., 1997, Illustrated handbook of physical-chemical properties and environmental fate for organic chemicals-Pesticide chemicals: New York, Lewis Publishers, v. V, 812 p.

Mackay, D.M., Shiu, W.Y., and Ma, K.C., 2000, Henry's law constant, in Boethling, R.S., and Mackay, D., eds., Handbook of property estimation methods for chemicals - Environmental and health sciences: Boca Raton, Florida, CRC Press LLC, $504 \mathrm{p}$.

Madsen, J.E., Sandstrom, M.W., and Zaugg, S.D., 2003, Methods of analysis by the U.S. Geological Survey National Water Quality Laboratory-A method supplement for the determination of fipronil and degradates in water by gas chromatography/mass spectrometry: U.S. Geological Survey Open-File Report 02-462, 11 p. [Also available at http://nwql.usgs.gov/Public/pubs/OFR02-462/OFR02-462. $h t m l$.

Martin, J.D., 2002, Variability of pesticide detections and concentrations in field replicate water samples collected for the National Water-Quality Assessment Program, 1992-97: U.S. Geological Survey Water-Resources Investigations Report 01-4178, 84 p. [Also available at. http://pubs.usgs. gov/wri/2001/wri01_4178/.]

Martin, J.D., and Eberle, Michael, 2011, Adjustment of pesticide concentrations for temporal changes in analytical recovery, 1992-2010: U.S. Geological Survey Data Series 630,11 p., 5 app. [Also available at http://pubs.usgs.gov/ $d s / 630 /$.

Martin, J.D., Eberle, Michael, and Nakagaki, Naomi, 2011, Sources and preparation of data for assessing trends in concentrations of pesticides in streams of the United States, 1992-2010: U.S. Geological Survey Data Series 655, 23 p., 5 app. [Also available at $h t t p: / / p u b s . u s g s . g o v / d s / 655 /$.]

Martin, J.D., Gilliom, R.J., and Schertz, T.J., 1999, Summary and evaluation of pesticides in field blanks collected for the National Water-Quality Assessment Program, 1992-95: U.S. Geological Survey Open-File Report 98-412, 102 p. [Also available at http://pubs.er.usgs.gov/publication/ ofr98412.]

Martin, J.D., Stone, W.W., Wydoski, D.S., and Sandstrom, M.W., 2009, Adjustment of pesticide concentrations for temporal changes in analytical recovery, 1992-2006: U.S. Geological Survey Scientific Investigations Report 2009-5189, 23 p., plus appendixes. [Also available at http:// pubs.usgs.gov/sir/2009/5189/.] 
Mueller, D.K., Martin, J.D., and Lopes, T.J., 1997, Qualitycontrol design for surface-water sampling in the National Water-Quality Assessment Program: U.S. Geological Survey Open-File Report 97-223, 17 p. Also available at $h t t p: / /$ pubs.usgs.gov/of/1997/223/.]

Neter, John, Kutner, M.H., Nachtsheim, C.J., and Wasserman, William, 1996, Applied linear statistical models (4th ed.): Boston, Mass., WCB/McGraw-Hill, 1,408 p.

Ngim, K.K., and Crosby, D.G., 2001, Abiotic processes influencing fipronil and desthiofipronil dissipation in California, USA, rice fields: Environmental Toxicology and Chemistry, v. 20 , no. 5 , p. $972-977$.

Oblinger Childress, C.J., Foreman, W.T., Connor, B.F., and Maloney, T.J., 1999, New reporting procedures based on long-term method detection levels and some considerations for interpretations of water-quality data provided by the U.S. Geological Survey National Water Quality Laboratory: U.S. Geological Survey Open-File Report 99-193, 19 p. [Also available at http://pubs.er.usgs.gov/publication/ ofr99193.]

Phillips, P.J., Ator, S.W., and Nystrom, E.A., 2007, Temporal changes in surface-water insecticide concentrations after the phaseout of diazinon and chlorpyrifos: Environmental Science and Technology, v. 41, no. 12, p. 4,246-4,251.

R Development Core Team, 2013, R-A language and environment for statistical computing: Vienna, Austria, $\mathrm{R}$ Foundation for Statistical Computing, accessed January 2, 2013, at http://www.R-project.org.

Ramesh, Atmakuru, and Balasudramanian, Muthukrishnan, 1999, Kinetics and hydrolysis of fenamiphos, fipronil, and trifluralin in aqueous buffer solutions: Journal of Agricultural and Food Chemistry, v. 47, p. 3,367-3,371.

Ryberg, K.R., and Vecchia, A.V., 2012, waterData-An R Package for retrieval, analysis, and anomaly calculation of daily water data, version 1.0: U.S. Geological Survey OpenFile Report 2012-1168, 8 p., accessed October 12, 2012, at http://pubs.usgs.gov/of/2012/1168/.

Ryberg, K.R., and Vecchia, A.V., 2013, seawaveQ-An $\mathrm{R}$ package providing a model and utilities for analyzing trends in chemical concentrations in streams with a seasonal wave (seawave) and adjustment for streamflow (Q) and other ancillary variables: U.S. Geological Survey Open-File Report 2013-1255, 13 p., with 3 appendixes, accessed December 30, 2013, at http://dx.doi.org/10.3133/ ofr 20131255 .

Ryberg, K.R., Vecchia, A.V., Martin, J.D., and Gilliom, R.J., 2010, Trends in pesticide concentrations in urban streams in the United States, 1992-2008: U.S. Geological Survey Scientific Investigations Report 2010-5139, 101 p. [Also available at http://pubs.usgs.gov/sir/2010/5139/.]
Shelton, L.R., 1994, Field guide for collecting and processing stream-water samples for the National Water-Quality Assessment Program: U.S. Geological Survey Open-File Report 94-455, $42 \mathrm{p}$.

Shiu, W.Y., Ma, K.C., Mackay, D., Seiber, J.N., and Wauchope, R.D., 1990, Solubilities of pesticide chemicals in water-Part II, Data compilation in Ware, G.W., ed., Reviews of environmental contamination and toxicology: New York, Springer Verlag 1990, v. 116, p. 15-187.

Staudinger, J., and Roberts, P.V., 2001, A critical compilation of Henry's law constant temperature dependence relations for organic compounds in dilute aqueous solutions: Chemosphere, v. 44, p. 561-576.

Stone, W.W., 2013, Estimated annual agricultural pesticide use for counties of the conterminous United States, 1992-2009: U.S. Geological Survey Data Series 752, 1-p. pamphlet, 14 tables, accessed July 22, 2013, at http://pubs.usgs.gov/ $d s / 752 /$.

Sullivan, D.J., Vecchia, A.V., Lorenz, D.L., Gilliom, R.J., and Martin, J.D., 2009, Trends in pesticide concentrations in corn-belt streams, 1996-2006: U.S. Geological Survey Scientific Investigations Report 2009-5132, 75 p. [Also available at $h t t p: / / p u b s . u s g s . g o v / s i r / 2009 / 5132 /$.

Talbert, R.E., and Burgos, N.R., 2007, History and management of herbicide-resistant barnyard grass (Echinochloa crus-galli) in Arkansas rice: Weed Technology, v. 21, no. 2, p. 324-331, accessed July 17, 2013, at http://www.jstor.org/ stable/4495855.

Thelin, G.P., and Stone, W.W., 2010, Method for estimating annual atrazine use for counties in the conterminous United States, 1992-2007: U.S. Geological Survey Scientific Investigations Report 2010-5034, 129 p., accessed December 12, 2013, at http://pubs.usgs.gov/sir/2010/5034/.

Thelin, G.P., and Stone, W.W., 2013, Estimation of annual agricultural pesticide use for counties of the conterminous United States, 1992-2009: U.S. Geological Survey Scientific Investigations Report 2013-5009, 54 p., accessed July 22, 2013, at http://pubs.usgs.gov/sir/2013/5009/.

Therneau, T.M., 2013, survival-A package for survival analysis in S: R package version 2.37-4, accessed July 22, 2013, at http://CRAN.R-project.org/package $=$ survival.

Toccalino, P.L., Gilliom, R.J., Lindsey, B.D. and Rupert, M.G., 2014, Pesticides in groundwater of the United States-Decadal-scale changes, 1993-2011: Ground Water, accessed March 15, 2014, at http://onlinelibrary.wiley.com/ doi/10.1111/gwat.12176/full.

Tomlin, C.D.S., ed., 2008, The e-pesticide manual, version 4.1: Thornton Health, United Kingdom, British Crop Production Council cd-rom. 
U.S. Department of Agriculture, 2005, Pesticide properties database (PPDB): U.S. Department of Agriculture, Agricultural Research Service database, accessed June 6, 2012, and July 12, 2013, at http://www.ars.usda.gov/services/docs. htm? docid $=14199$.

U.S. Environmental Protection Agency, 1984, Guidance for the reregistration of manufacturing-use and certain end-use pesticide products containing Cyanazine (100101), case number 066, accessed February 10, 2014, at http://www.epa. gov/nscep/index.html.

U.S. Environmental Protection Agency, 1993, R.E.D. factsButylate: EPA-738-F-93-014, 7 p., accessed July 16, 2013, at http://www.epa.gov/oppsrrd1/REDs/factsheets/0071fact. $p d f$.

U.S. Environmental Protection Agency, 1994a, R.E.D. facts_Pronamide: EPA-738-F-94-007, 7 p., accessed July 17, 2013, at http://www.epa.gov/oppsrrd1/REDs/ factsheets/0082fact.pdf.

U.S. Environmental Protection Agency, 1994b, Reregistration decision tebuthiuron, 205 p., accessed December 11, 2009, at http://www.epa.gov/oppsrrd1/REDs/old_reds/tebuthiuron. $p d f$.

U.S. Environmental Protection Agency, 1995a, Reregistration eligibility decision (RED) - Ethalfluralin: EPA 738-R-95001, 252 p., accessed July 16, 2013, at http://www.epa.gov/ oppsrrd1/REDs/2260.pdf.

U.S. Environmental Protection Agency, 1995b, Reregistration eligibility decision (RED) — Linuron: EPA 738-R-95-003, 272 p., accessed July 16, 2013, at http://www.epa.gov/ oppsrrd1/REDs/0047.pdf.

U.S. Environmental Protection Agency, 1995c, Reregistration eligibility decision (RED)—Metolachlor: EPA 738-R-95006, [variously paged], accessed May 25, 2011, at http:// www.epa.gov/oppsrrd1/REDs/0001.pdf.

U.S. Environmental Protection Agency, 1996a, New pesticide fact sheet: EPA-737-F-96-005, 10 p., accessed May 25, 2011, at http://nepis.epa.gov/Exe/ZyPURL. cgi? Dockey $=$ P1001KCY.txt.

U.S. Environmental Protection Agency, 1996b, Reregistration eligibility decision (RED) - Trifluralin, 221 p., accessed December 10, 2009, at http://www.epa.gov/oppsrrd1/ REDs/0179.pdf.

U.S. Environmental Protection Agency, 1997a, Reregistration eligibility decision (RED) - Pendimethalin, 223 p., accessed December 10, 2009, at http://www.epa.gov/oppsrrd1/ REDs/0187red.pdf.
U.S. Environmental Protection Agency, 1997b, Reregistration eligibility decision (RED) - Thiobencarb: EPA738R-97-013, 234 p., accessed July 17, 2013, at http://www. epa.gov/oppsrrd1/REDs/2665red.pdf.

U.S. Environmental Protection Agency, 1998a, Reregistration eligibility decision (RED) - Alachlor: EPA 738-R-98-020, 313 p., accessed May 25, 2012, at http://www.epa.gov/ oppsrrd1/REDs/0063.pdf.

U.S. Environmental Protection Agency, 1998b, Reregistration eligibility decision (RED) —DCPA: EPA 738-R-98-005, 199 p., accessed December 11, 2009, at http://www.epa.gov/ oppsrrd1/REDs/0270red.pdf.

U.S. Environmental Protection Agency, 1998c, Reregistration eligibility decision (RED)—Metribuzin: EPA 738-R-97006, 215 p., accessed June 5, 2012, at http://www.epa.gov/ oppsrrd1/REDs/0181red.pdf.

U.S. Environmental Protection Agency, 1998d, Reregistration eligibility decision (RED)—Propachlor: EPA 738-R-015, 227 p., accessed July 16, 2013, at http://www.epa.gov/ oppsrrd1/REDs/0177red.pdf.

U.S. Environmental Protection Agency, 1998e, Reregistration eligibility decision (RED) - Terbacil: EPA738-R-97-011, 206 p., accessed July 16, 2013, at http://www.epa.gov/ oppsrrd1/REDs/0039red.pdf.

U.S. Environmental Protection Agency, 1999a, R.E.D. factsO-Ethyl S-phenylethylphosphonodithiolate (Fonofos): EPA

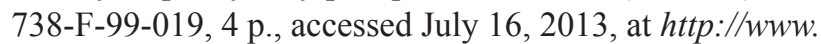
epa.gov/oppsrrd1/REDs/factsheets/0105fact.pdf.

U.S. Environmental Protection Agency, 1999b, Reregistration eligibility decision (RED)—EPTC: EPA 738-R-99-006, [variously paged], accessed June 5, 2012, at http://www.epa. gov/oppsrrd1/REDs/0064red.pdf.

U.S. Environmental Protection Agency, 1999c, Reregistration eligibility decision (RED) —Pebulate: EPA 738-R-99-005, 161 p., accessed July 16, 2013, at http://www.epa.gov/ oppsrrd1/REDs/2500red.pdf.

U.S. Environmental Protection Agency, 2000, Status of chemicals in special review: EPA-738-R-00-001, 59 p., accessed June 6, 2012, at http://www.epa.gov/oppsrrd1/ docs/sr00status.pdf.

U.S. Environmental Protection Agency, 2001, Reregistration eligibility decision for triallate: EPA 738-R-00-021, 110 p., accessed June 6, 2012, at http://www.epa.gov/oppsrrd1/ REDs/2695.pdf. 
U.S. Environmental Protection Agency, 2002, Interim Reregistration eligibility decision for Chlorpyrifos: EPA 738-R01-007, 259 p., accessed December 11, 2009, at http://www. epa.gov/pesticides/reregistration/REDs/chlorpyrifos_ired. $p d f$.

U.S. Environmental Protection Agency, 2004, Interim reregistration eligibility decision for carbaryl: 289 p., accessed January 11, 2010, at http://www.epa.gov/oppsrrd1/REDs/ carbaryl_ired.pdf.

U.S. Environmental Protection Agency, 2005, Reregistration eligibility decision for napropamide, $161 \mathrm{p}$., accessed July 17, 2013, at http://www.epa.gov/oppsrrd1/REDs/ napropamide_red.pdf.

U.S. Environmental Protection Agency, 2006a, Addendum to the 2002 lindane reregistration eligibility decision (RED): EPA 738-R-06-028, 20 p., accessed July 18, 2013, at http:// www.epa.gov/oppsrrd1/REDs/lindane_red_addendum.pdf.

U.S. Environmental Protection Agency, 2006b, Amendment to reregistration eligibility decision (RED) for propanil (March 2006) and the propanil RED (September 2003): EPA-HQOPP-2003-0348, 145 p., accessed July 16, 2013, at http:// www.epa.gov/oppsrrd1/REDs/propanil_red_combined.pdf.

U.S. Environmental Protection Agency, 2006c, Decision documents for atrazine: [variously paged], accessed May 25, 2012, at http://www.epa.gov/oppsrrdl/REDs/atrazine combined_docs.pdf.

U.S. Environmental Protection Agency, 2006d, Report of the Food Quality Protection Act (FQPA) Tolerance Reassessment Progress and Risk Management Decision (TRED) for acetochlor: EPA 738-R-00-009, 12 p., accessed February 10, 2013, at http://www.epa.gov/oppsrrd1/REDs/acetochlor tred.pdf.

U.S. Environmental Protection Agency, 2006e, Reregistration eligibility decision for diazinon: EPA 738-R-04-006, 112 p., accessed December 14, 2009, at http://www.epa.gov/ pesticides/reregistration/REDs/diazinon_red.pdf.

U.S. Environmental Protection Agency, 2006f, Reregistration eligibility decision for ethoprop: 182 p., accessed July 18, 2013, at http://www.epa.gov/pesticides/reregistration/REDs/ ethoprop_red.pdf.

U.S. Environmental Protection Agency, 2006g, Reregistration eligibility decision for simazine: EPA 738-R-06-008, 266 p., accessed May 25, 2011, at http://www.epa.gov/pesticides/ reregistration/REDs/simazine_red.pdf.
U.S. Environmental Protection Agency, 2007, Reregistration eligibility decision for carbofuran: EPA-HQOPP-2005-0162, [variously paged], accessed June 5, 2012, at http://www.epa.gov/oppsrrd1/reregistration/REDs/ carbofuran_red.pdf.

U.S. Environmental Protection Agency, 2008a, Amended reregistration eligibility decision (RED) for carbaryl: EPA-

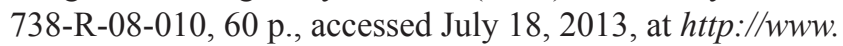
epa.gov/oppsrrd1/REDs/carbaryl-red-amended.pdf.

U.S. Environmental Protection Agency, 2008b, Amended reregistration eligibility decision (RED) for propargite: 174 p., accessed April 3, 2014, at http://www.epa.gov/ oppsrrd1/REDs/propargite_amend_red-10-09-08.pdf.

U.S. Environmental Protection Agency, 2008c, DiazinonPhase out of all residential uses of the insecticide: accessed December 11, 2009, at http://www.epa.gov/opp00001/ factsheets/chemicals/diazinon-factsheet.htm.

U.S. Environmental Protection Agency, 2008d, Reregistration eligibility decision for prometon: EPA 738-R-08-004, 50 p., accessed May 25, 2012, at http://www.epa.gov/pesticides/ reregistration/REDs/prometon-red.pdf.

U.S. Environmental Protection Agency, 2009, Reregistration eligibility decision (RED) for malathion, revised May 2009: EPA 738-R-06-030, 202 p., accessed June 5, 2012, at http:// www.epa.gov/oppsrrd1/REDs/malathion-red-revised.pdf.

U.S. Environmental Protection Agency, 2012, Estimating physical/chemical and environmental fate properties with EPI Suite ${ }^{\mathrm{TM}}$, chap. 5 of Sustainable futures, P2 framework manual: EPA-748-B12-001, p. 5-1-5-22, accessed July 23, 2013, at http://www.epa.gov/oppt/sf/pubs/epi-pchem-fate. $p d f$.

U.S. Geological Survey, [variously dated], National field manual for the collection of water-quality data: U.S. Geological Survey Techniques of Water-Resources Investigations, book 9, chaps. A1-A9, accessed April 1, 2008, at http:// water.usgs.gov/owq/FieldManual/.

U.S. Geological Survey, 1997, Changes to the NWQL's data formatting and transmittal software: National Water Quality Laboratory Technical Memorandum 97-08, accessed April 1, 2008, at http://nwql.usgs.gov/Public/tech_memos/ nwql.97-08.html.

University of Hertfordshire, 2009, The Pesticide Properties Database (PPDB) developed by the Agriculture \& Environment Research Unit, funded by United Kingdom national sources and the European Union-funded FOOTPRINT project (FP6-SSP-022704), accessed February 4, 2010 and July 12, 2013, at http://sitem.herts.ac.uk/aeru/footprint/en/. 
University of Hertfordshire, 2013, The University of Hertfordshire Agricultural substances database background and support information, 20 p., accessed July 23, 2013, at $h t t p: / /$ sitem.herts.ac.uk/aeru/footprint/en/.

Vecchia, A.V., Gilliom, R.J., Sullivan, D.J., Lorenz, D.L., and Martin, J.D., 2009, Trends in concentrations and use of agricultural herbicides for Corn Belt rivers, 1996-2006: Environmental Science and Technology, v. 43, p. 9,096-9,102.

Vecchia, A.V., Martin, J.D., and Gilliom, R.J., 2008, Modeling variability and trends in pesticide concentrations in streams: Journal of the American Water Resources Association, v. 44, no. 5 , p. $1,308-1,324$.

Wolfe, N.L., Zepp, R.G., Paris, D.F., Baughman, G.L., and Hollis, R.C., 1977, Methoxychlor and DDT degradation in water-Rates and products: Environmental Science and Technology, v. 11, no. 12, p. 1,077-1,081.

Zaugg, S.D., Sandstrom, M.W., Smith, S.G., and Fehlberg, K.M., 1995, Methods of analysis by the U.S. Geological Survey National Water Quality Laboratory-Determination of pesticides in water by $\mathrm{C}-18$ solid-phase extraction and capillary-column gas chromatography/mass spectrometry with selected-ion monitoring: U.S. Geological Survey Open-File Report 95-181, 49 p.

Zhu, Guonian, Wu, Huiming, Guo, Jiangfeng, and Kimaro, F.M.E., 2004, Microbial degradation of fipronil in clay loam soil: Water, Air, and Soil Pollution, v. 153, p. 35-44. 
Appendixes 


\section{Appendix 1. Preparation of Concentration Data for Trend Analysis}

Pesticide concentration data were prepared for trend analysis using the approach presented in Martin and others (2011, p. 6-20). The principal steps in data preparation for trend analysis were to (1) round concentrations to a consistent level of precision for the concentration range, (2) identify routine reporting levels used to report nondetections unaffected by matrix interference, (3) reassign the concentration value for routine nondetections to the long-term method detection level (maxLT-MDL), (4) adjust concentrations to compensate for temporal changes in bias of recovery of the gas chromatography/mass spectrometry (GCMS) analytical method, and (5) identify and remove samples considered inappropriate for trend analysis. In addition, at selected sites with sufficient low-level pesticide detections, the concentration for routine nondetections was reassigned from the maximum concentration of the maxLT-MDL to the median concentration of the low-level detections. These steps are further described in the following sections.

\section{Rounding of Concentrations to a Consistent Level of Precision}

The precision of pesticide data compiled for trend analysis has changed through time. Before April 1997, National Water-Quality Laboratory (NWQL) rounded pesticide data to a greater degree than data reported subsequently (U.S. Geological Survey, 1997). Concentration data were rounded consistently for various concentration ranges for trend analysis (Martin and others, 2011, table 4).

\section{Identification of Reporting Levels}

Two types of reporting levels were identified for the purposes of trend analysis: routine and raised. Nondetections of pesticides are reported as less than the "routine" reporting level (for example, less than $[<] 0.005$ micrograms per liter $[\mu \mathrm{g} / \mathrm{L}])$. A small number of samples have "matrix effects" or other analytical difficulties that interfere with the measurement of pesticide retention time or spectral characteristics. Under conditions of interference, pesticides cannot be identified/detected if they are present at concentrations less than the level of interference and are reported as nondetections less than a "raised" reporting level (for example, $<0.03 \mu \mathrm{g} / \mathrm{L}$; six times greater than the routine reporting level). Nondetections at raised reporting levels indicate the maximum possible concentration of the pesticide based on the magnitude of the interference. Raised reporting levels always are greater than routine reporting levels (for a given period). Raised reporting levels are sample specific and determined by the magnitude of the interference. Routine reporting levels are the same for all samples (for a given period) that are not affected by interference. The types and numerical values of routine reporting levels used to report nondetections analyzed by GCMS have changed over time. The concentration of the routine reporting level in effect for a given period was determined from USGS NWQL records and from review of the dataset.

\section{Reassignment of the Concentration Value for Routine Nondetections}

Temporal changes in the types and magnitude of reporting levels used to report routine nondetections have the potential to adversely affect trend analysis because they introduce a temporal "structure" to the time series of routine nondetections. The temporal structure of routine nondetections was removed for trend analysis by reassigning the temporally inconsistent censored values (the "less-than" values) assigned to nondetections to a uniform, temporally consistent censored value. Thus, all pesticide nondetections at routine reporting levels were censored at a concentration equal to the maximum concentration of the maxLT-MDL for water years 1994-2010 (the 1994 water year is the period from October 1, 1993 through September 30, 1994). Pesticide nondetections at raised reporting levels were treated as missing values and thus were not used for trend assessment. For most, but not all, pesticides and periods, reassigning the censored concentration of routine nondetections to the maxLT-MDL resulted in an increase in the nondetected "less than" concentration (Martin and others, 2011). The reporting level is not a detection limit for pesticides analyzed by GCMS and changes in the reporting level reflect changes in the quantitation variability of low-level concentrations or policy changes, not changes in detection capability.

In addition, we examined the hypothesis that detection ability has improved over time because of improved instrumentation. Except for two pesticides, there was no evidence to support this hypothesis (see appendix 2 and 3 in Ryberg and others, 2010).

\section{Adjustment of Concentrations for Temporal Changes in Recovery}

Temporal changes in the performance of the GCMS analytical method used to measure pesticide concentrations during 1992-2010 have the potential to mask true trends in environmental concentrations or to identify trends in environmental concentrations that are caused solely by trends in the performance of the GCMS method. Measured concentrations of pesticides were adjusted for temporal changes in analytical recovery using the approach presented in Martin and Eberle (2011) and summarized below.

Recovery of a pesticide compound is measured by analysis of "spiked" quality control (QC) samples. "Spikes" are water samples where a known amount of pesticide is added to the water sample. Recovery is the measured concentration 
of the pesticide divided by the expected concentration and recovery is expressed as a percentage. Recovery measures bias in the analytical method-bias is the systematic error in the measurement process and results in measurements that differ from the true (or expected) value in the same direction.

Data for recovery of pesticides in stream-water matrix spikes are provided in Martin and Eberle (2011). The recovery dataset was extended with approximately two additional years of data (through summer 2008) following similar procedures used to extend the pesticide concentration dataset (merging data before and after September 1, 2005). Modeled recovery in stream water is provided in appendix 5 of Martin and Eberle (2011). The median magnitude of temporal change in modeled recovery during 1992-2010 for 52 pesticides or degradates was 37.2 percent (Martin and Eberle, 2011).

Detected concentrations of pesticides were adjusted to 100 -percent recovery by dividing the measured concentration by the lowess-modeled recovery, where recovery was expressed as a fraction. Routine nondetections at maxLT-MDL were not adjusted for modeled recovery. Routine nondetections were not adjusted because adjustment would create a temporal structure to the time series of nondetections and defeat the original purpose of reassigning routine nondetections to the maxLT-MDL (see section "Reassignment of the Concentration Value for Routine Nondetections"). Recoveryadjusted concentrations were rounded consistently.

\section{Removal of Samples Considered Inappropriate for Trend Analysis}

Samples collected too frequently in time typically have highly correlated, redundant information that are inappropriate for use in trend analyses. A weekly sampling frequency was considered the maximum frequency suitable for trend analysis. All samples at a site were assigned to calendar weeks (Sunday through Saturday) and if two or more samples were collected during the same week, only the sample collected closest in time to 12 p.m. on Wednesday was retained for trend analysis.

\section{Reassignment of the Concentration Value for Selected Routine Nondetections to the Median Concentration of Low-Level Detections}

The GCMS analytical method does not have specified detection limits for each pesticide analyte. That is, there is no direct assessment by NWQL of the pesticide concentration where detection is 50 percent (or a larger percentage) probable. Instead, "reporting limits" are determined based on the variability of measured concentrations from low-concentration laboratory spikes (Oblinger Childress and others, 1999). This "signal-to-noise" based approach to determining detection works well for many types of analytical methods but is not well suited to the GCMS method, which requires pesticide identification (detection) before quantitation.

The maximum value of the maxLT-MDL has been used as a conservative estimate of the detection limit for previous studies of pesticide trends (Sullivan and others, 2009; Vecchia and others, 2009; Ryberg and others, 2010). Detections at concentrations less than maxLT-MDL were "censored" at maxLTMDL (reassigned to nondetections at the concentration of maxLT-MDL) and trends assessed. For the trend assessment in this report, a less conservative estimate of the detection limit was desired because many pesticides and sites selected for assessment had a large number of detections less than maxLTMDL (low-level detections) and using some of these low-level detections would increase the number of pesticides and sites that meet the criteria for trend assessment.

Both pesticide concentration and sample matrix are expected to affect detection capability. Pesticide concentrations less than but close to maxLT-MDL likely are detected almost as readily as concentrations at or just above maxLTMDL, whereas concentrations two orders of magnitude less than maxLT-MDL might rarely be detected. As was true for analytical recovery (Martin and others, 2009, p. 10-12, figs. 2 and 4), detection limits likely are a function of a sample matrix. Concentrations readily detected in one matrix might not be detected in a more problematic matrix.

The less conservative estimate of the detection limit used for trend assessment in this report is the median value of the low-level detections (qlow50), calculated separately for each pesticide and stream-water site combination. The site-specific estimate of the detection limit was calculated only for pesticide and stream-water site combinations with five or more low-level detections for the period of record. Where qlow50 was calculated, routine nondetections at maxLT-MDL and any low-level detection less than qlow50 were assumed to be censored at a concentration equal to qlow50 (the true concentration was assumed to be less than qlow50, but the actual concentration was not known). All detections with concentrations greater than or equal to qlow50 were left unchanged. For each pesticide-site combination with fewer than five low-level detections, qlow50 was set equal to maxLT-MDL and the same procedure described previously was used to prepare the data for trend assessment. Sampling site information is provided in Martin and others (2011), and the data used for trend analysis are available as a downloadable dataset in Martin and others (2011). 


\section{Appendix 2. Examples of Agricultural-Use Intensity Data and Interval Censored Trend Analysis}

Pesticide use on a countywide level was estimated using a method developed by Thelin and Stone (2013) and the use estimates for 1992 through 2009 were published in Stone (2013). The 2010 use estimates are considered preliminary and were derived following the same methodology and data sources (Baker and Stone, 2013). The exceptions to this method are the sites in California, SANTA, SJQUN, and SACRA (table 1 in report), for which use estimates were obtained from annual Department of Pesticide Regulation Pesticide Use Reports (Thelin and Stone, 2013).

The countywide use estimates include two series of annual estimates, called EPest-low and EPest-high. According to Thelin and Stone (2013), EPest-low and EPest-high are two variations on their method for estimating countywide use. Both EPest-low and EPest-high "incorporated surveyed and extrapolated rates to estimate pesticide use for counties" (Thelin and Stone, 2013, p. 12). The two estimates differ in how they treat missing data for pesticide-by-crop combinations. EPest-low treats missing reports as zero use and EPest-high uses a method to estimate the use based on the use in surrounding areas (Thelin and Stone, 2013).

Annual pesticide use for each individual basin in this study was calculated by proportioning the county-level pesticide use estimates (both EPest-low and EPest-high) to the cropland in each county for all counties contained in or overlapping the basin. For counties partially within a basin, pesticide use was equal to the proportion of cropland in the county that was contained in the basin, and was obtained using a geographic information system to overlay mapped land cover with digital maps of drainage basins and county boundaries. The annual pesticide use for each basin was divided by the basin area to obtain estimated annual use intensity (kilogram per year per square kilometer). For those basins with area outside of the United States, the annual use intensity is the agricultural use within the United States per year divided by the basin area within the United States (N.T. Baker, U.S. Geological Survey, written commun., 2013).

Annual agricultural use intensity data for major river basins were compiled for pesticides with agricultural uses. This excluded prometon, which is not registered for use on crops; dieldrin, which was not used for agricultural purposes during of this study; and all pesticide degradation products. This excluded LVWSH (table 1 in the report), a basin that had no reported agricultural uses of the pesticides in this study. Despite available agricultural use data, we also intentionally excluded ATCHF. The Atchafalaya River is used as a distributary for Mississippi River floodwaters; therefore, at times, the pesticide concentrations in the Atchafalaya River are not representative of the agricultural uses in the Atchafalaya River Basin, but of agricultural uses over a much larger area. Some individual pesticide/site combinations did not have reported agricultural uses; therefore, the number of sites with use intensity estimates differs among pesticides.

The EPest-high and EPest-low agricultural use estimates for atrazine for 57 of the major river basins are shown in figure $2-1$. Atrazine is one of the most widely used agricultural pesticides for which use estimates were calculated (Thelin and Stone, 2013) and has been the subject of past efforts to estimate usage (Thelin and Stone, 2010). Few of the EPest-high and EPest-low estimates for the 57 sites were zero (one EPestlow value of zero for YLOW-FS, one pair of EPest-high and EPest-low estimates for SANTA, and most of the estimates for TRUCK were zero; replaced by very small values for graphing on a $\log$ scale, fig. 2-1). For most of the sites, there is a great deal of agreement between EPest-high and EPest-low. The sites with the greatest difference between EPest-high and EPest-low are in the northwestern part of the Midwest region (MIZZ-CB, YLOW-FS, YLOW-SN, MIZZ-GD; fig. 2) and the northeastern part of the Pacific region (SNAK-KH, PLOUS; fig. 2).

The EPest-high and EPest-low agricultural use estimates for diazinon for 57 of the major river basins are shown in figure 2-2. Compared to atrazine, diazinon has more values of zero for both EPest-high and EPest-low. There is also less general agreement between EPest-high and EPest-low. The three California sites (SANTA, SJQUN, and SACRA) stand out from the rest because use estimates were obtained from the California Department of Pesticide Regulation Pesticide Use Reports and EPest-high and EPest-low are the same at these sites (Thelin and Stone, 2013).

Trends in agricultural use were of interest to compare to concentration trends in this study; however, there were a number of challenges inherent with the use estimates. First, when calculating agricultural use and concentration trends over the same period for comparison, there are only 10 agricultural use observations, which results in low power for detecting trends. Second, it has not been determined that one use estimate series is better than the other, so considerable exploratory data analysis was done to better understand EPest-high and EPest-low and their difference across time and basins. Finally, the number of zero values introduces additional challenges for trend analysis. For example, the single zero EPest-low estimate for MOHWK diazinon in 2003 is suspect given the nonzero values in all years before and after. In other cases for diazinon, both the EPest-high and EPest-low estimates go to zero at the end of the period of record. This is not unreasonable because there are potential replacement chemicals for diazinon, such as fipronil, and all diazinon concentration trends reported in this study are down for the 2001-10 period; however, zero values do not work for some trend analysis methods.

After exploratory data analysis and trend estimation using EPest-high and EPest-low separately and together, it was 


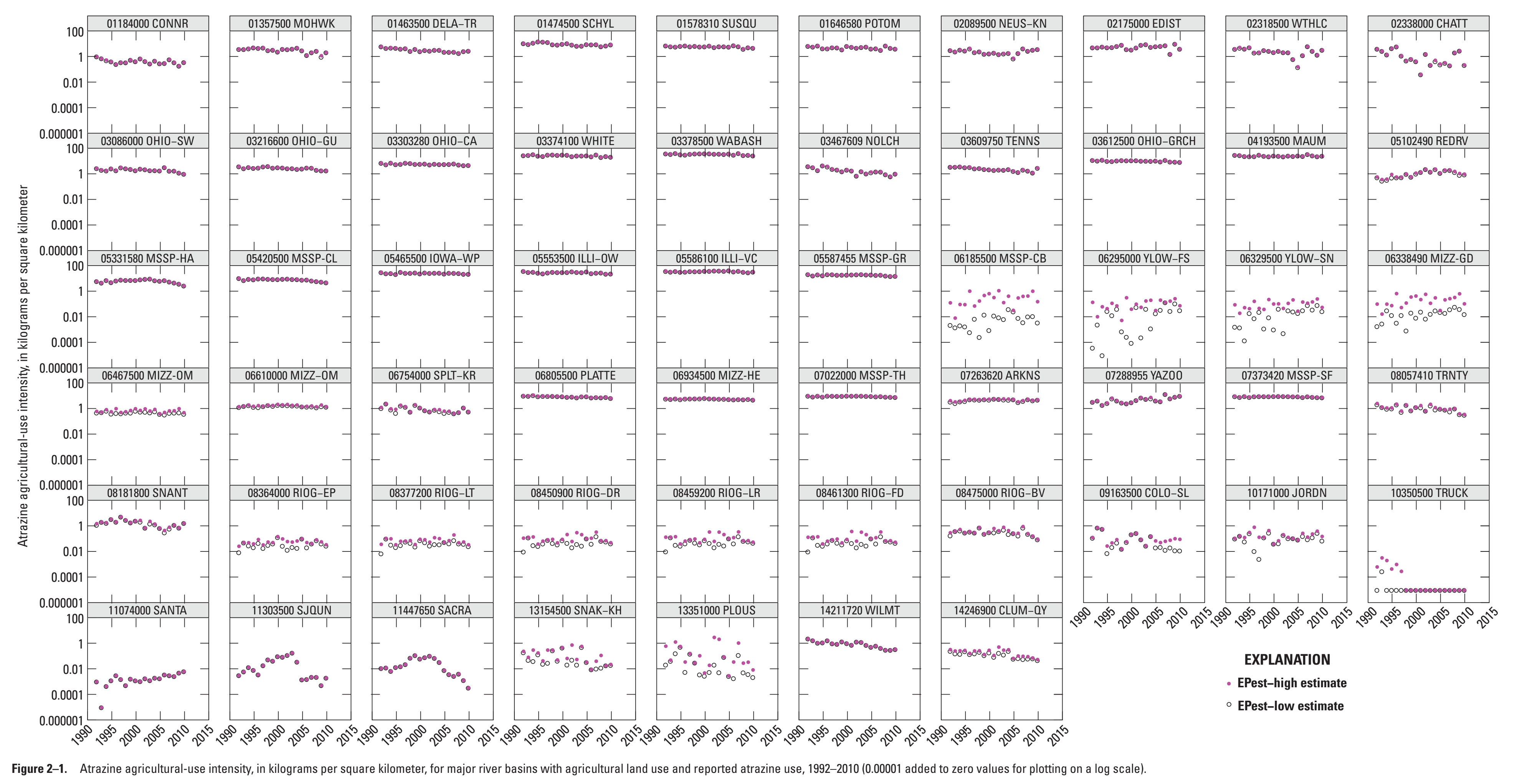


62 Pesticide Trends in Major Rivers of the United States, 1992-2010

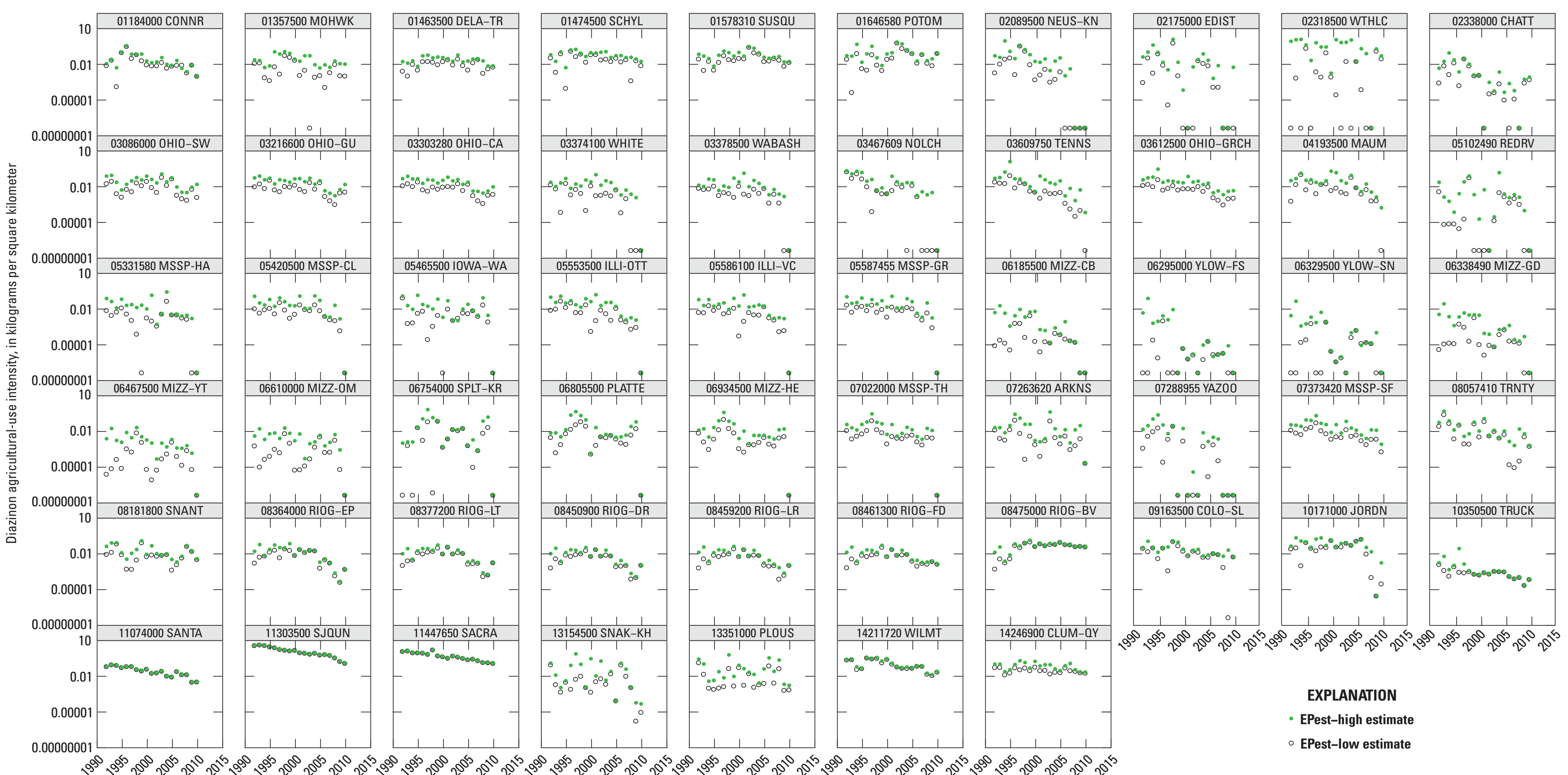

Figure 2-2. Diazinon agricultural-use intensity, in kilograms per square kilometer, for major river basins with agricultural land use and reported diazinon use, $1992-2010$ (0.00000005 added to zero values for plotting on a log scale). 
determined that the best approach was to use interval-censored regression incorporating both of the estimates. In addition, the potential period/site/pesticide trend cases were reduced to only those for which there were 10 nonzero estimates for both EPest-high and EPest low. The trend analysis followed the method of Vecchia and others (2009), where trends in agricultural use for each period/site/pesticide combination were obtained by linear regression with log-transformed annual use intensity as the dependent variable and the year as the independent variable,

$$
\log U I(t)=\beta_{0}+\beta_{1} t+\varepsilon(t)
$$

where

$U I(t) \quad$ is the estimate of pesticide use intensity

(kilograms per year per square kilometer) for the site/pesticide combination for the year $t$,

$\beta_{0}$ and $\beta_{1} \quad$ are regression coefficients, and

$\varepsilon(t) \quad$ is the model error for the year $t$.

When the EPest-high and EPest-low estimates differed (and neither were zero or missing), the estimate was an interval censored between the two. When the two estimates were the same, a single, noncensored value was used. A parametric survival regression model was fit using maximum likelihood methods for censored data, using the statistical software R and the survival package for R (R Development Core Team, 2013; Therneau, 2013).

Trend examples for 1992-2001 for the sites in the rightmost column of figure 2-1 (CHATT, REDRV, MIZZ-GD, TRNTY) are shown in figure 2-3. CHATT had agreement between EPest-high and EPest-low and a statistically significant ( $p$-value less than 0.10) downtrend in agricultural use for atrazine. REDRIV had less agreement between EPesthigh and EPest-low, but the estimates did not differ greatly, which resulted in a statistically significant uptrend. MIZZ-GD had more disagreement between EPest-high and E-Pest low. Although the trend coefficient for MIZZ-GD is the second largest in this example and positive, it is not statistically significant. TRNTY had similar EPest-high and EPest-low estimates, but did not have a significant trend. The last site in the rightmost column of figure $2-1$ (TRUCK) contained zeroes in the estimates and therefore a trend was not calculated.

Trends were calculated during 1992-2001, 1997-2006, and 2001-10, with the exceptions of acetochlor, which was not registered for use until 1994, and fipronil, which was not registered for use until 1996. The combination of a low number of observations (10) and censored regression introduced another issue for trend analysis. Sometimes, the survival regression method could not converge on a solution for the parameter estimates.
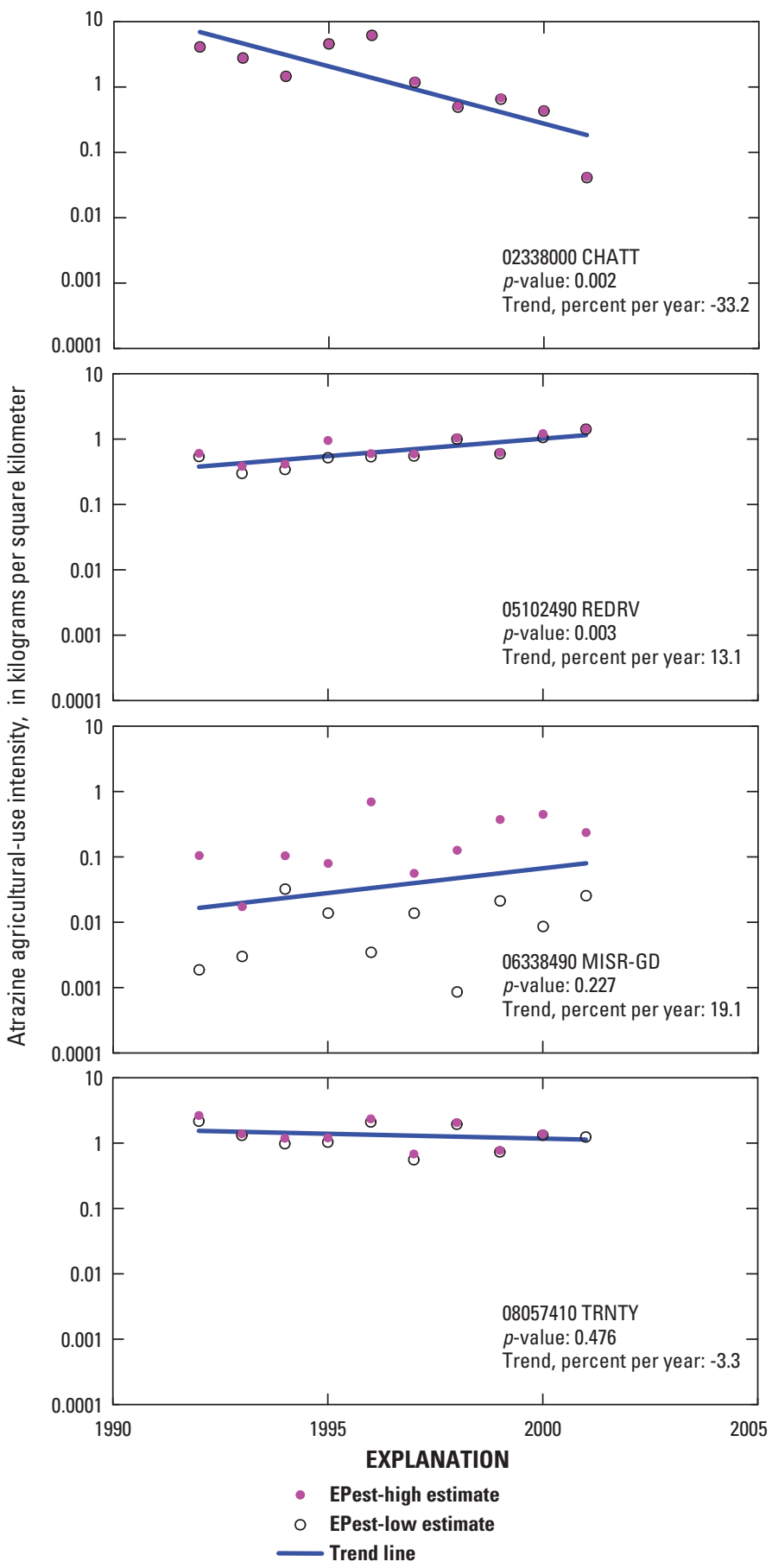

Figure 2-3. EPest-high and EPest-low estimates and censored regression trends for atrazine at four sites, 1992-2010. 
Publishing support provided by: Rolla Publishing Service Center

For more information concerning this publication, contact: Director, USGS North Dakota Water Science Center 821 East Interstate Avenue Bismarck, North Dakota 58503

(701) 250-7400

Or visit the North Dakota Water Science Center Web site at: http://nd.water.usgs.gov/ 



\section{$\frac{\mathbb{2}}{3}$}

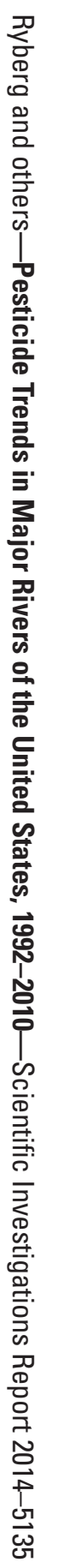

